Aus der Abteilung Neuroanatomie

(Prof. Dr. med. J. Staiger)

im Zentrum Anatomie

der Medizinischen Fakultät der Universität Göttingen

\title{
Untersuchung der Schwann-Zell-Migration und -Proliferation im peripheren sympathischen Nervensystem der Maus
}

\section{INAUGURAL - DISSERTATION}

\author{
zur Erlangung des Doktorgrades \\ der Medizinischen Fakultät \\ der Georg-August-Universität zu Göttingen
}

vorgelegt von

Julia Schmücker

aus

Bielefeld

Göttingen 2011 
Dekan: Prof. Dr. med. C. Frömmel

I. Berichterstatter: Privatdozent Dr. med. M. Rickmann

II. Berichterstatter/in:

III. Berichterstatter/in:

Tag der mündlichen Prüfung: 


\section{Inhaltsverzeichnis}

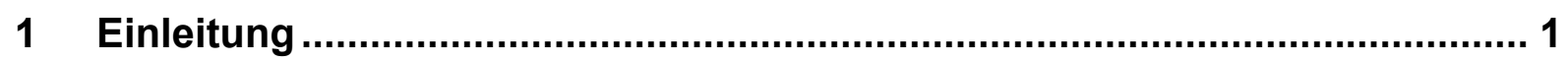

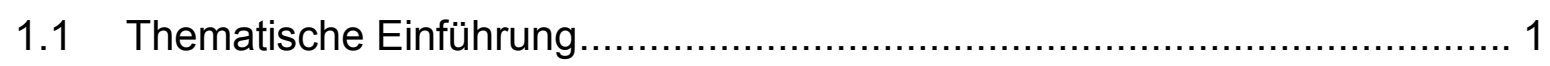

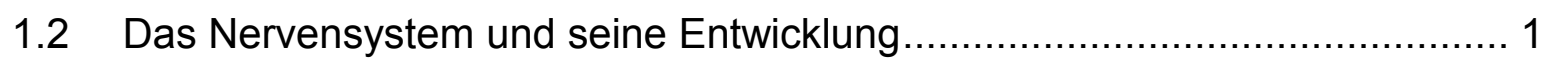

1.2.1 Das Ganglion cervicale superius.................................................. 2

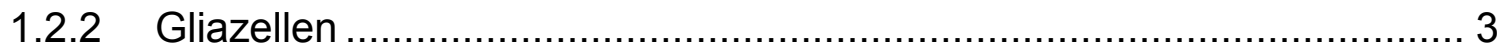

1.2.2.1 Erkrankungen, die mit einer Fehlfunktion der Gliazellen

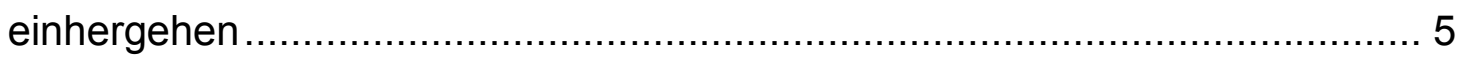

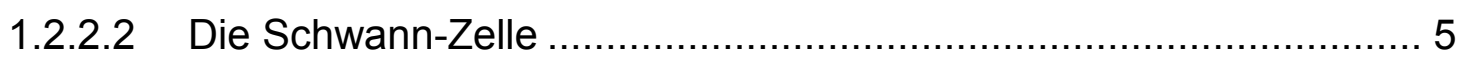

1.3 Faktoren, die Einfluss auf die Entwicklung von Schwann-Zellen nehmen... 11

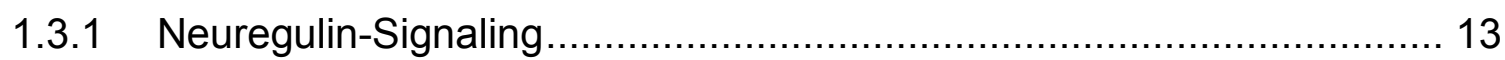

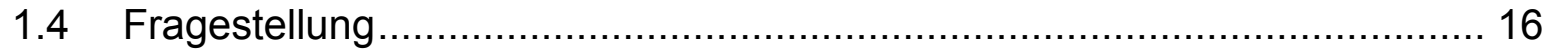

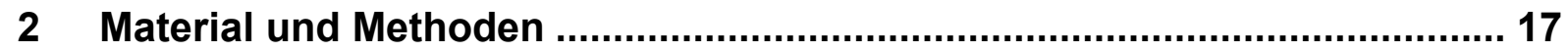

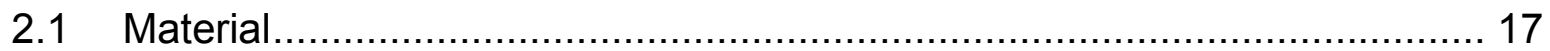

2.1.1 Tiere

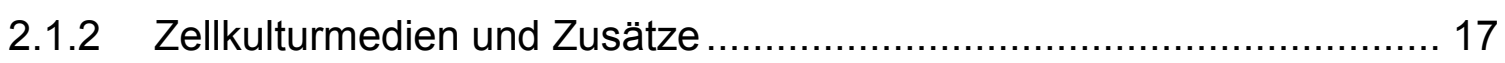

2.1.3 Puffer und Lösungen für zellbiologische Arbeiten .............................. 17

2.1.4 Puffer und Lösungen für zytochemische Arbeiten............................. 18

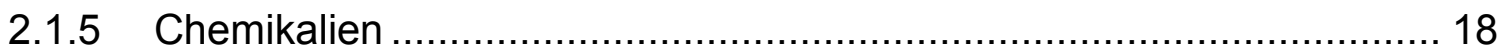

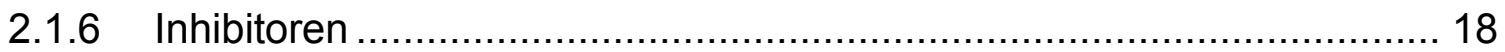

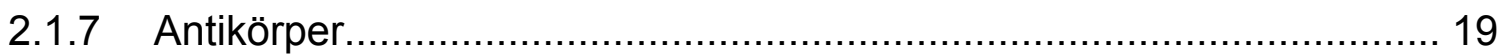

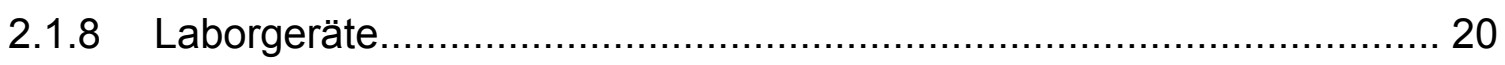

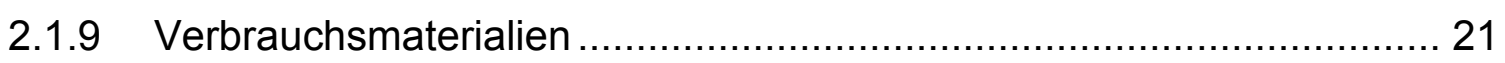

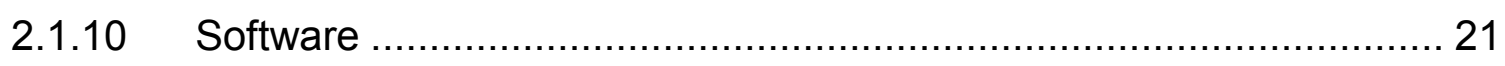

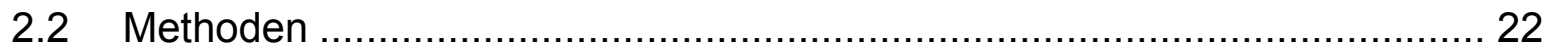

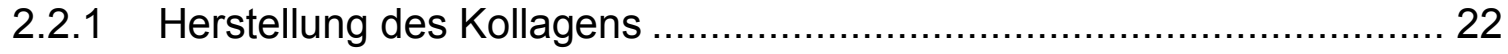

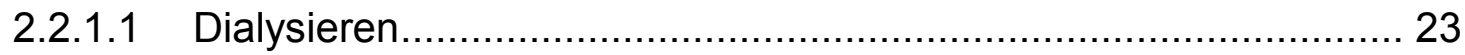

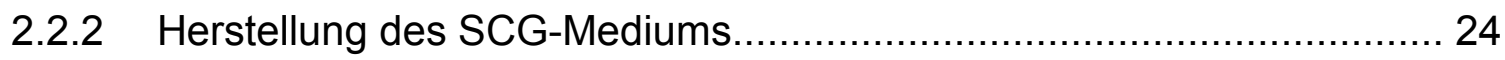

2.2.3 Herstellung des konzentrierten Mediums (CM) ................................ 24

2.2.4 Präparation der Embryonen .......................................................... 24

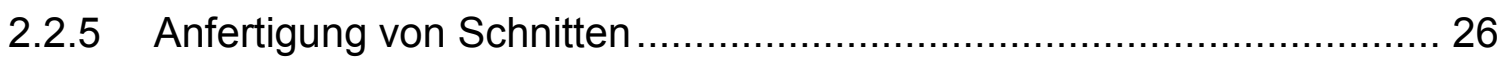

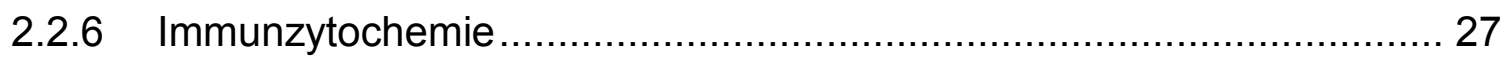




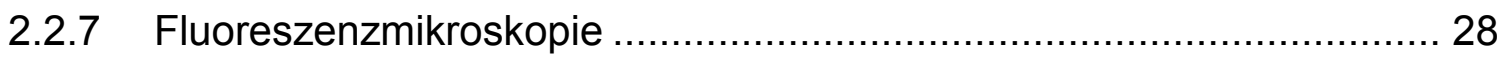

2.2.8 Messung des Abstandes Kern-Axonende ......................................... 28

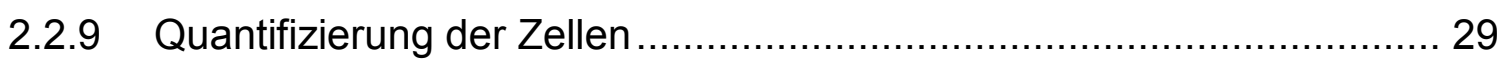

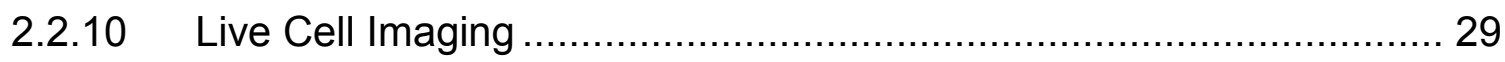

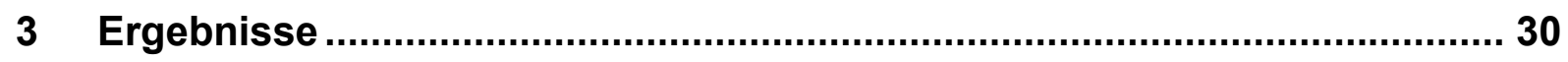

3.1 Assay zur Analyse der Schwann-Zell-Migration .................................... 30

3.1.1 Charakterisierung der migrierenden Zellen als Schwann-Zellen ........... 31

3.1.2 Erb-Inhibitor-Behandlung unmittelbar nach Explantation ..................... 32

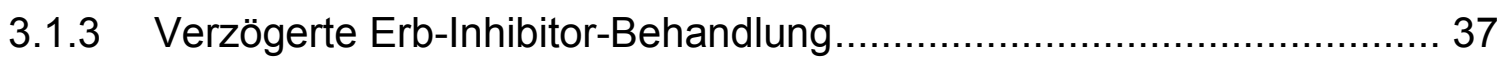

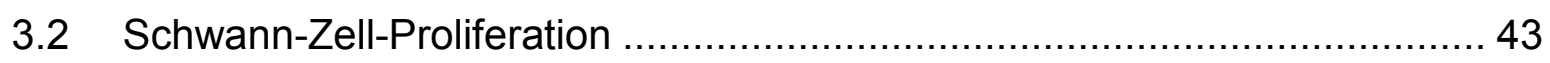

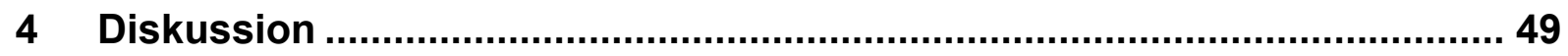

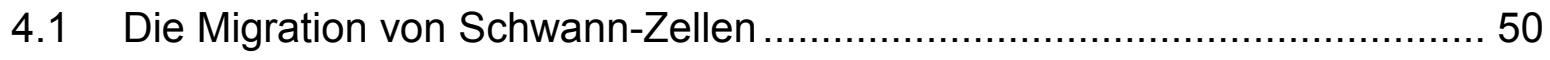

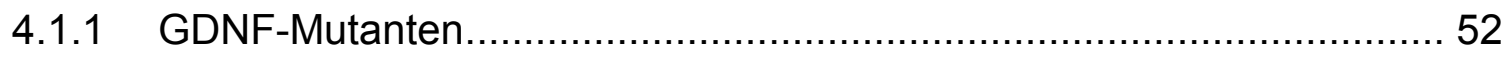

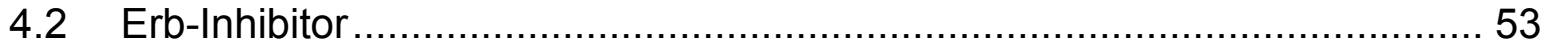

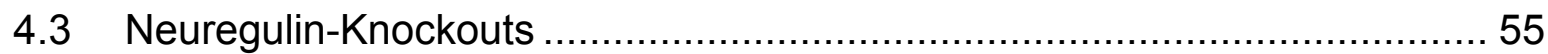

4.4 Neuregulin ist ein bedeutender Faktor für die Migration und Proliferation von

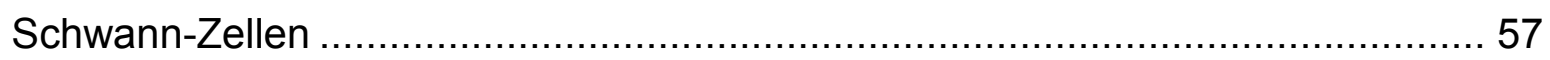

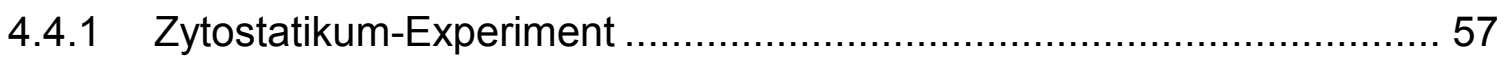

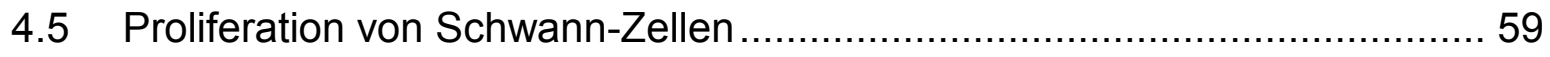

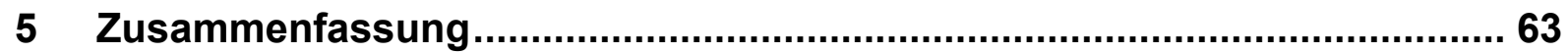

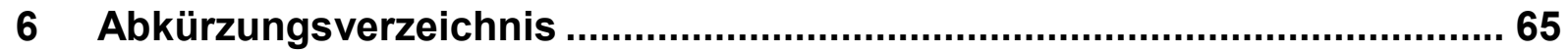

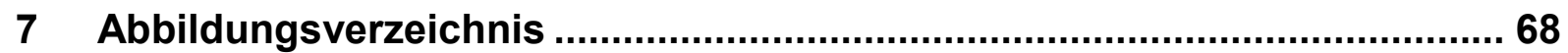

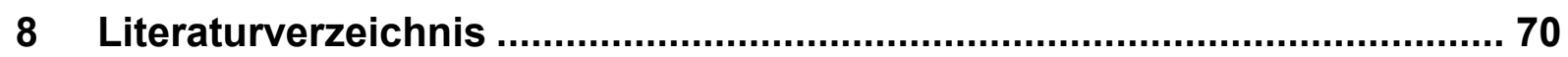




\section{Einleitung}

\subsection{Thematische Einführung}

Das Nervensystem beschäftigt schon seit Jahrzehnten viele Naturwissenschaftler. Bei seiner Komplexität ist dies auch nicht weiter erstaunlich, steuert es doch alle willkürlichen Handlungen des Menschen und integriert ebenso neben der hormonellen Steuerung die Kognition, Empfindung und die Wahrnehmung. Zunächst beschäftigten sich Forscher mit morphologischen Begebenheiten. So wandte sich schon Leonardo Da Vinci Ende des 15. Jahrhunderts der Anatomie des Menschen $\mathrm{zu}$, indem er zusammen mit Ärzten an Leichen sezierte und seine Beobachtungen anschließend aufzeichnete. Ebenso befasste sich beispielsweise der Mediziner und Nobelpreisträger Santiago Ramón y Cajal Ende des 19. Jahrhunderts mit der Anatomie des Nervensystems, indem er mit Hilfe der Golgi-Färbung zu der Erkenntnis kam, dass die kleinste Einheit des Nervensystems das Neuron ist. Erst sehr viel später, durch Entwicklung der molekularen Biologie, der modernen Mikroskopie und Zellbiologie, konnte man auch funktionelle Fragen adressieren.

\subsection{Das Nervensystem und seine Entwicklung}

Das Nervensystem ist aus zwei Bestandteilen aufgebaut, dem Zentralen Nervensystem (ZNS) und dem Peripheren Nervensystem (PNS). Das ZNS umfasst das Gehirn und das Rückenmark; in diesen Strukturen laufen alle Informationen aus dem Körper und aus der Umwelt zusammen, werden dort verarbeitet, um dann bei Bedarf adäquate Reaktionen in Form von Bewegungen, Verhalten oder Organtätigkeit zu erzeugen. So werden alle aus der Peripherie einlaufenden sensorischen Reize, also alle Afferenzen des PNS, zum Gehirn weitergeleitet, wo die zentrale Verarbeitung stattfindet. Die Entwicklung des ZNS beginnt beim Menschen um den fünfzehnten Embryonaltag mit der Ausbildung der Neuralplatte, die sich aus dem Neuroektoderm entwickelt und sich weiter differenziert in die Neuralrinne und schließlich zum Neuralrohr wird. Zellen, die sich im Laufe der Entwicklung zu Zellen 
des PNS differenzieren, stammen vom lateralen Bereich der Neuralplatte, nehmen aber nicht an der Bildung des Neuralrohrs teil, sondern ordnen sich über- oder beidseits der Neuralanlage vom Mesencephalon bis zum kaudalen Spinalbereich an und bilden im Verlauf der Entwicklung die Neuralleiste (Schiebler 2005). Abkömmlinge der Neuralleiste sind: Satellitenzellen der peripheren Ganglien, primär sensorische Neurone, multipolare sympathische Neuralleistenzellen, prävertebrale Plexus, enterische Neuralleistenzellen, parasympathische enterische Plexus; chromaffine Zellen des Nebennierenmarks, Melanozyten der Haut, das Mesektoderm des Kopfbereichs und Schwann-Zellen (LeDouarin und Smith 1988). Das PNS setzt sich zusammen aus den Hirnnerven, den Rückenmarksnerven und den peripheren Ganglien und leitet sowohl exterozeptive, propriozeptive als auch vegetative Impulse und ist maßgebend für die willkürliche Steuerung motorischer Funktionen. Die Hirnnerven umfassen zwölf Hirnnervenpaare, deren Kerne in Nuclei im Hirnstamm liegen. Abgesehen von den Hirnnerven I und II zählen alle anderen, also die Hirnnerven III-XII eindeutig zum PNS, werden von Schwann-Zellen umhüllt und besitzen immer mindestens eine Durchtrittsstelle innerhalb des knöchernen Schädels mit zum Teil langem extraduralen Verlauf (N. abducens). Ganglien gehören als dritter Hauptbestandteil zum PNS. Sie zeichnen sich als kleine Knötchen ab, die in den Verlauf peripherer Nerven eingeschaltet sind. Das äußere Erscheinungsbild kommt dadurch zustande, dass sich im Ganglion die Zellkörper der Nervenzellen anhäufen. In den prävertebralen Ganglien des sympathischen Nervensystems erfolgt die Umschaltung von prä- auf postganglionär und stellt die erste zentrale Verarbeitungsstelle außerhalb des ZNS dar.

\subsubsection{Das Ganglion cervicale superius}

Bei dieser Arbeit wurde das Ganglion cervicale superius (SCG) als Modellsystem verwendet und war Grundlage aller Versuche. Das SCG liegt in Höhe des zweiten bis dritten Halswirbels und hat enge topographische Beziehung zur Arteria carotis interna und zur Vena jugularis interna, die das Ganglion von ventral bedecken. Ventrolateral verläuft der Nervus vagus (N. X). Das SCG ist eine Komponente des sympathischen Nervensystems und fungiert als Umschaltstation. Die Somata der 
afferenten Fasern haben ihren Ursprung in den ersten Brustsegmenten des Rückenmarks und ziehen über den Truncus sympathicus zum SCG. Unter anderem entspringen alle postganglionären Fasern, die den gesamten Kopf versorgen, dem SCG; dies sind Z.B. der N. jugularis, der sich dem N. glossopharyngeus (N.IX) und dem N. vagus (N.X) anschließt, dem Verlauf der Arterien folgend, und diesem sympathische Fasern zufließen lässt. Des Weiteren der N. caroticus internus, von dem unter anderem das Auge, die Tränendrüse und die Nasenschleimhaut mit Sympathikusfasern versorgt werden; über die $\mathrm{Nn}$. carotici externi gelangt der sympathische Nervenanteil zu den großen Mundspeicheldrüsen und der Mundschleimhaut. Ferner gehen die Rr. laryngopharyngei aus dem SCG hervor, die zu Larynx und Pharynx ziehen sowie der N. cardiacus cervicalis superior, der sowohl post- als auch präganglionäre Fasern enthält, die erst später im Plexus cardiacus umgeschaltet werden. Neben den Funktionen des Nervensystems, welche in sehr weiten Bereichen noch nicht erforscht sind, ist auch die Entwicklung des Nervensystems Gegenstand der aktuellen Forschung und in vielen Bereichen noch rätselhaft.

\subsubsection{Gliazellen}

Die Axone der Nervenzellen sind sowohl im ZNS als auch im PNS von einer Hülle umgeben, die von Gliazellen gebildet wird. Die Bezeichnung Gliazelle fasst viele Unterarten von Zellen zusammen, die jedoch alle sowohl topographisch als auch funktionell in enger Verbindung zu Neuronen stehen. Man grenzt folgende Gliazelltypen gegeneinander ab: Im ZNS differenziert man zwischen verschiedenen Zellformen: der Makroglia, zu der die Astrozyten und die Oligodendroglia gezählt werden, die Mikroglia und die Müllerzellen der Netzhaut. Gliazellen des PNS sind die Schwann-Zellen, die Mantelzellen und die Teloglia der motorischen Endplatte. Den Gliazellen werden verschiedene Funktionen zugeschrieben, wozu vor allem die elektrische Isolation des Neurons sowie eine nutritive Funktion gehören. Ferner dienen sie durch die entsprechende Gewebearchitektur als Stütze für die Neuronen und sind überdies zu Stoffwechsel- und Transportprozessen befähigt, wodurch sie also an der Regulation des neuronalen Mikromilieus beteiligt sind. Weiterhin wird 
innen eine Abwehrfunktion zugesprochen sowie eine Beteiligung an der Bildung der Blut-Hirn-Schranke. Nicht zuletzt vermögen sie durch Proliferation verletztes Nervengewebe zu reparieren (Jessen und Mirsky 2008). Alle Arten von Gliazellen sind aber fortwährend mit Nervengewebe assoziiert, wobei jeder Typ von Gliazelle für eine Funktion spezialisiert ist. So sind sowohl im ZNS als auch im PNS die Axone der Nervenzelle von einer von Gliazellen gebildeten Hülle umgeben, die sich jedoch in beiden Systemen unterscheidet. Ein weiterer Unterschied liegt darin, dass im Gegensatz zum ZNS im PNS auch unmyelinisierte Axone von Glia umgeben sind. Im ZNS ist es ein Oligodendrozyt, der mehrere Axone umhüllt und damit die Myelinscheide bildet. Oligodendrozyten entstammen dem Neuroepithel des Neuralrohrs, und es wird sogar angenommen, dass sie und die Neurone selbst auf eine gemeinsame Vorläuferzelle zurückgehen (He et al. 2001) bzw. insgesamt verschiedene Arten von Vorläuferzellen existieren und ein weiterer Anteil der Oligodendrozyten genauso wie Astrozyten von Glioblasten abstammt (Rao und Mayer-Proschel 1997). Die Ranvier-Knoten liegen im ZNS völlig frei, da die innerste Lamelle des Oligodendrozyten sehr früh endet und die äußerste die übrigen Endigungen zwar überdeckt, den Ranvier-Knoten aber frei lässt. Im Internodium gebildete schräge Einkerbungen, die Zytoplasma enthalten, sogenannte SchmidtLanterman-Inzisuren, fehlen im ZNS. Im PNS übernehmen die aus der Neuralleiste hervorgehenden Schwann-Zellen die Aufgabe der Umhüllung und Myelinisierung der Neurone. Handelt es sich um eine Myelin-bildende Schwann-Zelle, entsteht ein 1:1Verhältnis zwischen Schwann-Zelle und Axon. Während der Entwicklung bildet der Zellleib der Schwann-Zelle eine Furche, in die das Axon eingebettet wird (Kahle und Frotscher 2005). Durch Vertiefung dieser Furche und spiraliges Wandern der Schwann-Zelle um das Axon entsteht das Mesaxon (Kahle und Frotscher 2005). Handelt es sich allerdings um eine nicht-myelinisierende Schwann-Zelle, bewerkstelligt sie die Umhüllung mehrerer Axone. Es ist hervorzuheben, dass auch nicht-myelinisierte Nerven durchaus von Schwann-Zellen umgeben sind, die hier in erster Linie eine nutritive Funktion übernehmen. Ob ein Nerv letztendlich myelinisiert wird oder nicht, hängt von den Durchmessern seiner Axone ab; ab einer Größe von $1 \mu \mathrm{m}$ wird das Axon von Myelin-bildenden Schwann-Zellen umgeben, alle kleineren Axone werden von nicht-myelinisierenden Schwann-Zellen umgeben, welche anschließend in Remak-Bündel integriert werden. Die Hülle der marklosen Fasern 
besteht dann aus dem Zytoplasma der Schwann-Zelle, und ihre Fortsätze schieben sich über die paranodale Region und das Axon; der Ranvier-Knoten liegt demgemäß im Gegensatz zum ZNS nicht frei.

\subsubsection{Erkrankungen, die mit einer Fehlfunktion der Gliazellen einhergehen}

Die Bedeutung der Myelinisierung wird besonders bei der Betrachtung von Erkrankungen, die mit einer Fehlfunktion der Myelinisierung einhergehen, deutlich. Die unter diesem Gesichtspunkt bekannteste und häufigste Erkrankung ist die Multiple Sklerose (MS). Hierbei kommt es durch Entmarkungsherde im ZNS zur Demyelinisierung von Axonen, was häufig zu spastischen Paresen, Blasenentleerungsstörungen, Einschränkung des Sehvermögens sowie im späteren Verlauf auch zum Hirnorganischen Psychosyndrom führen kann. Eine weitere Erkrankung, die auf einen Verlust bzw. eine Zerstörung der Myelinscheide zurückzuführen ist, ist die Chronisch Inflammatorische Demyelinisierende Polyradikuloneuropathie (CIDP), welche sich im Gegensatz zur MS im PNS abspielt. Es wird eine autoimmune Ursache angenommen, wobei Autoantikörper die Myelinschicht in der Peripherie, also die Schwann-Zellen, angreifen. Es kann in der Folge sowohl zu motorischen als auch sensorischen Einschränkungen kommen. Von der CIDP abzugrenzen ist das Guillain-Barré-Syndrom (GBS), bei dem es infektassoziiert zum autoimmunen Angriff der Schwann-Zellen kommt. Im Gegensatz zur CIDP findet hier ein rasch progredienter Verlauf statt; bei Nichtbehandlung der Erkrankung kann das GBS durch Beteiligung der Nerven der Atemmuskulatur zum Tod führen. Die Schwere dieser Erkrankungen veranschaulicht nochmals die Bedeutsamkeit der von den Schwann-Zellen gebildeten Myelinschicht.

\subsubsection{Die Schwann-Zelle}

Die aus der Neuralleiste hervorgehenden Schwann-Zellen sind die am genauesten beschriebenen Gliazellen des PNS. Im adulten Nervensystem werden vier Arten von 
Schwann-Zellen voneinander unterschieden. Den Ursprung dieser funktionell unterschiedlichen Arten von Schwann-Zellen nehmen jedoch alle von den Neuralleistenzellen, welche sich dann postnatal durch Axon-vermittelte Signale zu Schwann-Zellen mit jeweiliger spezifischer Charakteristik differenzieren (Corfas et al. 2004). Es existieren zum einen perisynaptische Schwann-Zellen, welche an der motorischen Endplatte lokalisiert sind, zum anderen Satellitenzellen, die in Verbindung mit neuronalen Zellkörpern in peripheren Ganglien stehen (Corfas et al. 2004). Den bedeutendsten Teil der Schwann-Zellen stellen jedoch zwei andere Unterarten dar; zunächst diejenigen Schwann-Zellen, die die Fähigkeit besitzen, einen peripheren Nerv zu myelinisieren, und dann diejenigen, die diese Fertigkeit unter normalen Gegebenheiten nicht nutzen. Ob sich eine Vorläuferzelle zu einer myelinisierenden oder nicht-myelinisierenden Schwann-Zelle entwickelt, geschieht ganz in Abhängigkeit davon, was für einen Nerv sie umhüllt und wie dessen Faserqualität und vor allem dessen Faserdicke beschaffen ist (Birchmeier und Nave 2008). Je dicker die Myelinscheide, desto schneller leitet der Nerv. Im menschlichen Körper sind die Nervenfasern der Muskelspindeln diejenigen mit dem größten Durchmesser und der schnellsten Leitungsgeschwindigkeit. Die sogenannten CFasern sind nicht myelinisiert und leiten vergleichsweise langsam; über sie werden der langsame Schmerz und die Temperaturempfindung weitergeleitet. Besitzt ein Nerv die entsprechenden Voraussetzungen myelinisiert zu werden, legt sich sein Axon in eine flache Einbuchtung einer Schwann-Zelle (Schiebler 2005). Dadurch, dass sich die Einbuchtung vertieft, nähern sich ihre Ränder, und es entsteht eine Membranduplikatur; das Mesaxon (Kahle und Frotscher 2005, Schiebler 2005). Dieses wird spiralig um das Axon aufgewickelt, wahrscheinlich, indem die SchwannZelle um das eingeschlossene Axon wandert (Kahle und Frotscher 2005). Am Axon des myelinisierten Nervs entstehen in regelmäßigen Abständen tiefe Einschnürungen der Markscheide, sodass hier ein Ranvier-Schnürknoten gebildet wird. Diese Bereiche sind gekennzeichnet durch eine hohe Dichte an Natriumkanälen, wodurch die saltatorische Erregungsleitung gewährleistet wird. Die dadurch entstehenden Abschnitte zwischen den Ranvier-Schnürknoten entsprechen beim peripheren Nerven den Internodien. Ein Internodium kommt der Ausdehnung einer SchwannZelle gleich. Im Elektronenmikroskop erkennt man am Ranvier-Knoten allerdings, dass die Enden der Schwann-Zellen feine Ausläufer haben, die locker miteinander 
verzahnt sind bzw. füßchenförmig an das Axon herantreten (Schiebler 2005). Je nachdem, wie groß der Durchmesser des Axons und wie dick die durch die Schwann-Zellen gebildete Markscheide ist, kann die Geschwindigkeit der axonalen Erregungsleitung variieren. Je größer der Durchmesser des Axons und je dicker die Markscheide, desto schneller leitet der Nerv. Unter diesem Aspekt werden die Nervenfasern klassifiziert. Die markhaltigen Nervenfasern werden absteigend nach ihrer Leitungsgeschwindigkeit in fünf Hauptgruppen von Aa bis B unterteilt.

Schon früh in der Entwicklung nimmt die Bildung von marklosen Nervenfasern einen anderen Weg. Auch sie sind zwar von Schwann-Zellen umschlossen, jedoch liegt der erste Unterschied darin, dass hier nicht jedes einzelne Axon von einer SchwannZelle umgeben wird, sondern, dass eine Schwann-Zelle mehrere Axone gleichzeitig umschließt und somit sogenannte Remak-Bündel bildet. Sie stellen die von einer Schwann-Zelle zusammengefassten Nervenfasern dar. Die Dicke der Bündel nimmt von zentral nach peripher ab. Zum zweiten können auch bei marklosen Fasern Mesaxone gebildet werden, gleichwohl verschmelzen die Membranschichten nicht. Da sie nicht auswachsen, kann sich auch keine Myelinscheide bilden. Durch diese Tatsache können auch keine Ranvier-Schnürknoten entstehen, wodurch eine saltatorische Erregungsleitung unmöglich gemacht wird. Vielmehr entsteht eine kontinuierlich wellenartige Fortleitung, indem sich die Membranpermeabilität entlang des Axons ändert und die Erregung weiterleitet. Dadurch, dass meist mehrere Axone von einer Hüllzelle umgeben werden, entstehen Leitstränge. Häufig kommt es vor, dass einzelne Axone aus einem Leitstrang in einen anderen überwechseln; dies ermöglicht Vernetzungen. Ein einzelner Nerv wird in seiner ganzen Länge nicht nur von einer Schwann-Zelle umhüllt; wie bereits erwähnt, entspricht ein Internodium der Entfaltung einer einzelnen Schwann-Zelle, und betrachtet man den Verlauf eines Nerven in seiner Gesamtheit, so sind unzählige Schwann-Zellen daran beteiligt, inn zu umgeben. Die Anzahl der Schwann-Zellen, die den postnatalen Nerv umhüllt, ist genau reguliert und abgestimmt durch die Proliferation und auch die Apoptose der Schwann-Zell-Vorläuferzellen, induziert durch TGF- $\beta$ und Neuregulin (D'Antonio et al. 2006, Grinspan et al. 1996).

Vor allem aber auch schon pränatal scheint Neuregulin eine fundamentale Rolle bei der Migration und Proliferation von Schwann-Zellen bzw. ihren Vorläuferzellen zuzukommen. Die Regulation der Anzahl der Schwann-Zellen ist entscheidend für 
die weitere Entwicklung. Besteht eine Überproduktion von Schwann-Zellen, so entsteht ein sogenanntes Schwannom; ein Benigner Peripherer Nervenscheidentumor (BPNST). Bei einem Mangel an Schwann-Zellen wiederum entsteht die Gefahr, dass der umhüllte Nerv nicht ausreichend mit Nährstoffen versorgt wird, wodurch die essentielle Rolle der Regulation der Anzahl von SchwannZellen verdeutlicht wird. In der Forschung ist bisher sehr viel Arbeit und Aufwand in die Erkundung von Prozessen wie Myelinisierung und Remyelinisierung nach Nervenverletzung gelegt worden. Myelinisierende sowie nicht-myelinisierende Schwann-Zellen besitzen die Kapazität, auf Nervenverletzung zu reagieren, indem sie zu einem Phänotyp zurückkehren, der dem unreifer Schwann-Zellen ähnelt (Abb. 1). Ebenso können Schwann-Zell-Vorläufer, zumindest in vitro, zu anderen Neuralleistenderivaten umgeleitet werden (Hagedorn et al. 1999, Dupin et al. 2003). 


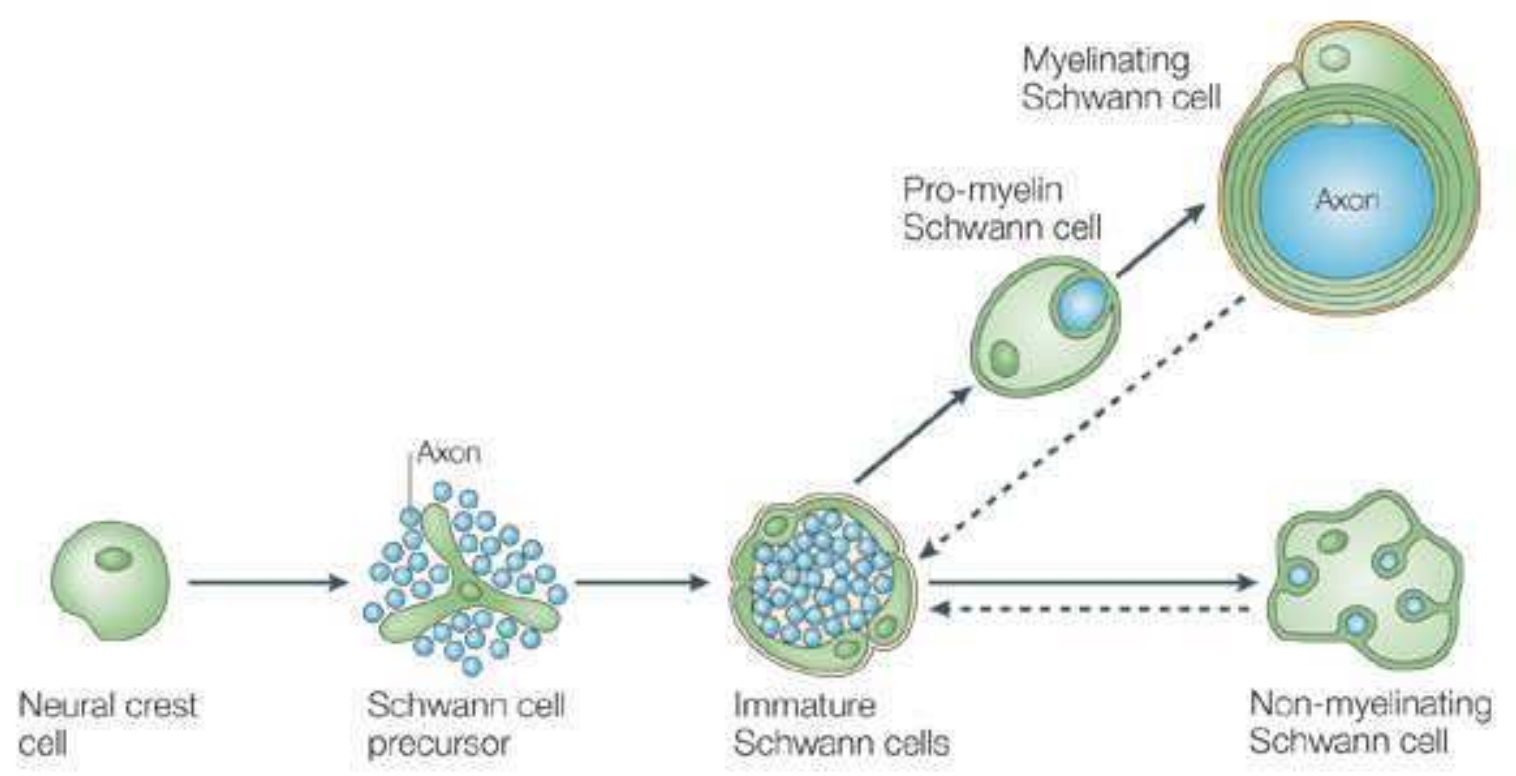

Abb. 1: Schematische Darstellung der Schwann-Zell-Entwicklung sowie der Möglichkeit der Rückbildung von myelinisierenden zu nicht-myelinisierenden Schwann-Zellen (Jessen und Mirsky 2005, S. 673)

Einige Faktoren scheinen bedeutsame Rollen während dieser Prozesse zu spielen; als wesentliche Faktoren seien TGF- $\beta$ (Day et al. 2003) sowie GDNF (Zhang L et al. 2009, Höke et al. 2003) zu nennen. Obwohl diese beiden Faktoren eine Auswirkung auf die Myelinisierung von Nervenfasern gezeigt haben, wird angenommen, dass sie mit dem Hauptkontrollprotein Neuregulin interagieren und dessen Anwesenheit und Wirkung aufrechterhalten. Neuregulin steuert in der Tat direkt die Myelinisierung (Michailov et al. 2004, Taveggia et al. 2005, Birchmeier und Nave 2008). In Abwesenheit von ErbB2/ErbB3, den beiden für die Interaktion von Neuregulin mit Neuralleistenzellen und Schwann-Zellen wichtigsten Rezeptoren, bleibt das Myelin, das von den Schwann-Zellen gebildet wird, dünn; diese Beobachtung weist auf das Erfordernis des Neuregulin-Signals hin, welches für die Bildung der Dicke der Myelinschicht benötigt wird (Garratt et al. 2000b). Neuregulin1 ist eher als ErbB2/ErbB3 der limitierende Faktor bei dem Wachstum der Myelinmembran (Michailov et al. 2004). 
Der Anteil an Schwann-Zell-Bildung wird reguliert durch das Gleichgewicht mehrerer entgegenwirkender Signale: $\beta$-Neureguline, die die Differenzierung von SchwannZell-Vorläufern zu Schwann-Zellen begünstigen, und Endotheline, die diese Entwicklung durch Interaktion an Endothelin-B-Rezeptoren hemmen. Hinzukommend wurden Transkriptionsfaktoren mit inhibierender Aktivität mit dieser Entwicklungsperiode in Verbindung gebracht. Dabei handelt es sich um AP-2Transkriptionsfaktoren, insbesondere um AP-2 $\alpha$. Dieser Faktor sowie AP-2 $\gamma$ sind in frühen embryonalen Nerven vorhanden, wohingegen AP-2 $\beta$ nicht vorkommt; die maximale mRNA-Konzentration wurde an E12/13 der Maus beobachtet (Stewart et al. 2001), was mit der Präsenz von Schwann-Zell-Vorläufern am Nerv korreliert. Infolgedessen werden inhibierende Einflüsse der AP-2-Transkriptionsfaktoren auch auf Schwann-Zellen angenommen. Bekräftigt wird diese Annahme durch Versuche, in denen sich eine verminderte Expression von AP-2a-mRNA am Tag E12/13 der Maus mit den vorherrschenden Schritten in der Schwann-Zell-Entwicklung, dem Übergang von der Schwann-Zell-Vorläuferzelle zur Schwann-Zelle deckt, und zwar in vivo und in vitro (Stewart et al. 2001). AP-2a regt die Transkription von zahlreichen Genen, eingeschlossen die positiven und negativen Wachstums-Regulatoren cErbB2 und p21 WAF/CIP, an (Zeng et al. 1997). Semiquantitative RT-PCR, Western Blotting und Immunhistochemie sowie Antikörpergabe dienten in Versuchen dem Beweis, dass AP-2 $\alpha$ nur in frühen Phasen der Entwicklung, und zwar in dem Zeitabschnitt, in dem der Nerv von Schwann-Zell-Vorläufern besiedelt ist, präsent war (Stewart et al. 2001). Auf diese Weise korreliert das Auftreten von AP-2a-und AP-2y-mRNA am E12 bzw. E15 (Ratte) mit dieser Beobachtung, allerdings zu späteren Zeitpunkten nicht mehr. Hinzukommend wurde die Existenz von AP-2 $\alpha$ nur in den Nuclei von Schwann-Zell-Vorläufern, jedoch nicht in Schwann-Zellen, festgestellt.

Eine Reihe von Proteinen, z.B. der p75-Neurotrophin-Rezeptor, das fibrilläre saure Glia-Protein sowie NCAM, welche von unreifen Schwann-Zellen exprimiert werden, werden in myelinisierenden Zellen herunterreguliert (Jessen und Mirsky 1992). Diese Unterdrückung hängt vom Kontakt zu Axonen ab, und die Proteine tauchen in Schwann-Zellen, die axonalem Kontakt entzogen wurden, wieder auf. In Bezug auf AP-2 konnte keine Korrelation festgestellt werden; bei Entzug von Axon-Kontakt zu Schwann-Zellen versagte die AP-2-Expression. 
Es wurde gezeigt (Stewart et al. 2001), dass sich Schwann-Zell-Vorläufer im Neuregulin-enthaltenden Medium zu Schwann-Zellen entwickeln. Entsprechende Experimente deuten darauf hin, dass die „AP-2a-Downregulation“ ein Teil des koordinierten Programms bei der Bildung von Schwann-Zellen aus ihren Vorläuferzellen ist. Schlussfolgernd wurden AP-2 $\alpha$ und AP-2 $\gamma$ als NegativRegulatoren bei der Schwann-Zell-Entwicklung detektiert (Stewart et al. 2001); beide Transkriptionsfaktoren werden beim Übergang von Vorläuferzellen zu SchwannZellen stark herunterreguliert.

Ebenso wie NRG1 einen positiven Effekt auf die Entwicklung von Schwann-Zellen hat, existieren Faktoren, die eine überschießende Aktivität von Schwann-Zellen verhindern und als Negativ-Regulatoren bezeichnet werden. Krox-20 ist ein solcher Faktor; hierbei handelt es sich um einen Transkriptionsfaktor mit drei Zinkfingerdomänen, der der Myelinisierung von Schwann-Zellen entgegenwirkt; Anlass für diese Annahme gab ein Versuch, in dem Mäuse mit mangelndem bzw. fehlendem Krox-20 keine myelinisierten Axone exprimierten (Mirsky und Jessen 1996). Oct-6 ist ein weiterer solcher Faktor, der prinzipiell die gleichen Aufgaben wie Krox-20 übernimmt und überdies den „Promyelin-Myelin-Übergang“ stimuliert (Ghislain und Charnay 2006).

\subsection{Faktoren, die Einfluss auf die Entwicklung von Schwann-Zellen nehmen}

Welches Signal leitend in der Entwicklung und Proliferation der Schwann-Zellen ist, ist noch unklar. Ein Ansatz ist die These, dass sich Neuralleistenzellen erst dann zu Schwann-Zellen entwickeln können, wenn sie sich in Verbindung mit auswachsenden Axonen setzen, um embryonale Nerven zu formen (Mirsky und Jessen 1996). Nach entsprechenden Experimenten bestätigte sich zumindest die Annahme, dass die molekularen Mechanismen, die sowohl die zeitliche als auch die räumliche Anpassung vom Auswachsen des Axons und der Neuralleisten-Zell-Migration garantieren, unabhängig voneinander wirken. Ergänzend stellt sich die Frage, ab 
welchem Zeitpunkt der Entwicklung die Entscheidung über die terminale Differenzierung der Neuralleistenzellen fällt.

Abgesehen von NRG1 und anderen beeinflussenden Faktoren fungiert NDF (NeuDifferentiation-Factor) als bestimmender Wachstumsfaktor bei der Differenzierung von Neuralleistenzellen; unklar bleibt lediglich die Frage, in welchem Zeitraum der Entwicklung NDF seine Wirkung entfaltet. Anhalt für die Annahme, dass Neuralleistenzellen schon vor Zusammentreffen mit Axonen den Weg zur Entwicklung zu Gliazellen eingeschlagen haben, gibt die Beobachtung, dass in Ratten einige wandernde Neuralleistenzellen das P0-Protein und mRNA exprimieren (Zhang SM et al. 1995, Bhattacharyya et al. 1991). P0 kann als spezifischer Marker für die Gliazelllinie angesehen werden; widersprüchliche Beweise für die ausschließliche Exprimierung von P0 in Schwann-Zellen liegen nicht vor. In-vitro- und in-vivo-Experimente haben gezeigt, dass Schwann-Zellen auch in Abwesenheit von Axonen eine basale Expression von P0 aufweisen, die allerdings durch axonalen Kontakt moduliert werden kann (Mirsky und Jessen 1996).

In diesem Bezugsrahmen ergibt sich die Frage, in welcher Form und in welchem Ausmaß Schwann-Zellen axonaler Kontakte und Signale bedürfen. Außer Frage steht sicherlich die Tatsache, dass sich embryonale Schwann-Zellen ohne einwirkende NRG-Effekte nicht „normgerecht“ entwickeln; autokrine Überlebensmechanismen existieren erst postnatal. Dieser Schluss beruht auf der Gegebenheit, dass postnatale Nervendurchtrennung nicht mit einem signifikanten Schwann-Zell-Untergang korreliert (Jessen und Mirsky 1999). Schwann-ZellÜberlebenssignale sind u.a. Insulin-like-Growth-Factor, Neurotrophin-3 und Plateletderived-Growth-Factor-BB, die ebenso wie der Schwann-Zell-Marker S-100 erst postnatal in reifen Schwann-Zellen nachgewiesen werden können. S-100B ist der entsprechende Subtyp der S-100-Genfamilie, der als spezifischer Gliazellmarker gilt. Bei S-100B handelt es sich um ein Kalzium-bindendes Protein, das auch in der klinischen Diagnostik als Marker für eine Hirnschädigung Verwendung findet, da es nach Hirnschädigung zur Freisetzung von S-100B aus Gliazellen kommt. Allerdings gibt es auch pränatal Mechanismen, die der Apoptose von Schwann-ZellVorläuferzellen entgegenwirken, wenn diese den axonalen Kontakt verlieren; in diesem Fall wurde in vitro beobachtet, dass DRG-Neurone und isolierte axonale Membranen die Fähigkeit zur Sekretion von Proteinen aufweisen, die die Schwann- 
Zell -Vorläufer-Apoptose verhindern (Jessen und Mirsky 1999). Folglich kann man davon ausgehen, dass auch in vivo Signale, die von Axonen stammen, am Überleben und der Differenzierung von Schwann-Zellen wesentlich beteiligt sind. Man nimmt an, dass auch andere Isoformen des Neuregulins Einfluss auf die Schwann-Zell-Entwicklung nehmen, jedoch sind diese Signalwege noch nicht abschließend geklärt. Die Typ-II-Isoform des Neuregulin1, ein lösliches, sezerniertes Molekül, und Neuregulin2 werden von Neuronen in Spinalganglien und im Rückenmark produziert und ermöglichen unter Umständen das Überleben der Schwann-Zell-Vorläuferzellen, sofern sie sich in unmittelbarer Nähe zu dieser Bezugsquelle befinden (Garratt et al. 2000a).

\subsubsection{Neuregulin-Signaling}

Eine wesentliche Rolle bei der Schwann-Zell-Entwicklung spielt NRG-1, ein Protein, das mit Rezeptoren der EGFR-Familie interagiert. Diese Interaktionen wurden auch schon pränatal beobachtet (Garratt et al. 2000a). Durch alternatives Spleißen entstehen verschiedene Isoformen des Neuregulins, wobei das Typ-III-NRG1 die bedeutendste Form darstellt und von sensiblen Neuronen und Motoneuronen produziert wird. Die weiteren Isoformen werden durchnummeriert von I - VI; Neuregulin I ist auch bekannt als NDF, Neuregulin II auch als Glial-Growth-Factor-2. Nichtsdestoweniger verfügen alle Isoformen des Neuregulins über eine einzige gemeinsame Eigenschaft: die EGF-Domäne, welche allein hinreichend zur Bindung an Rezeptoren und Auslösung von Signalwegen ist (Garratt et al. 2000a). Die beiden wichtigsten Rezeptoren für die Interaktion mit NRG1 in der Entwicklung von Neuralleistenzellen und Schwann-Zellen sind ErbB3 und ErbB2. Obwohl ErbB3 initial in den meisten, wenn nicht allen Neuralleistenzellen exprimiert wird, wird dieser Rezeptor anschließend in vielen Derivaten deaktiviert. Wichtige Ausnahmen sind Gliazellen, insbesondere die Abstammungslinie der Schwann-Zellen, welche weiterhin das Gen exprimiert (Garratt et al. 2000a). Neuregulin spielt allerdings auch schon bei der Migration der Vorläufer aus der Neurralleiste eine Rolle. In Versuchen an Mäusen mit Mutationen im Neuregulin1, ErbB2 oder ErbB3 ist die Migration von sympathischen Neuralleistenzellen zum Grenzstrang abnormal (Britsch et al. 1998). 
Die Typ-I-Isoform des Neuregulin1 stellt das Signal, das für die initiale Entwicklung des sympathischen Nervensystems benötigt wird, bereit, und wird sowohl am Ursprungsort als auch entlang des Migrationsweges bis zum Zielort der sympathischen Neuralleistenzellen exprimiert. (Britsch et al. 1998). Abbildung 2 zeigt das Neuregulin-Signaling über die ErbB-Rezeptoren mit anschließender Signalkaskade, die zur Migration von Schwann-Zellen führt. Ebenfalls schematisch dargestellt ist das GDNF-Signaling über NCAM bzw. Ret, welches die Migration nicht über Src-Kinasen beeinflusst.
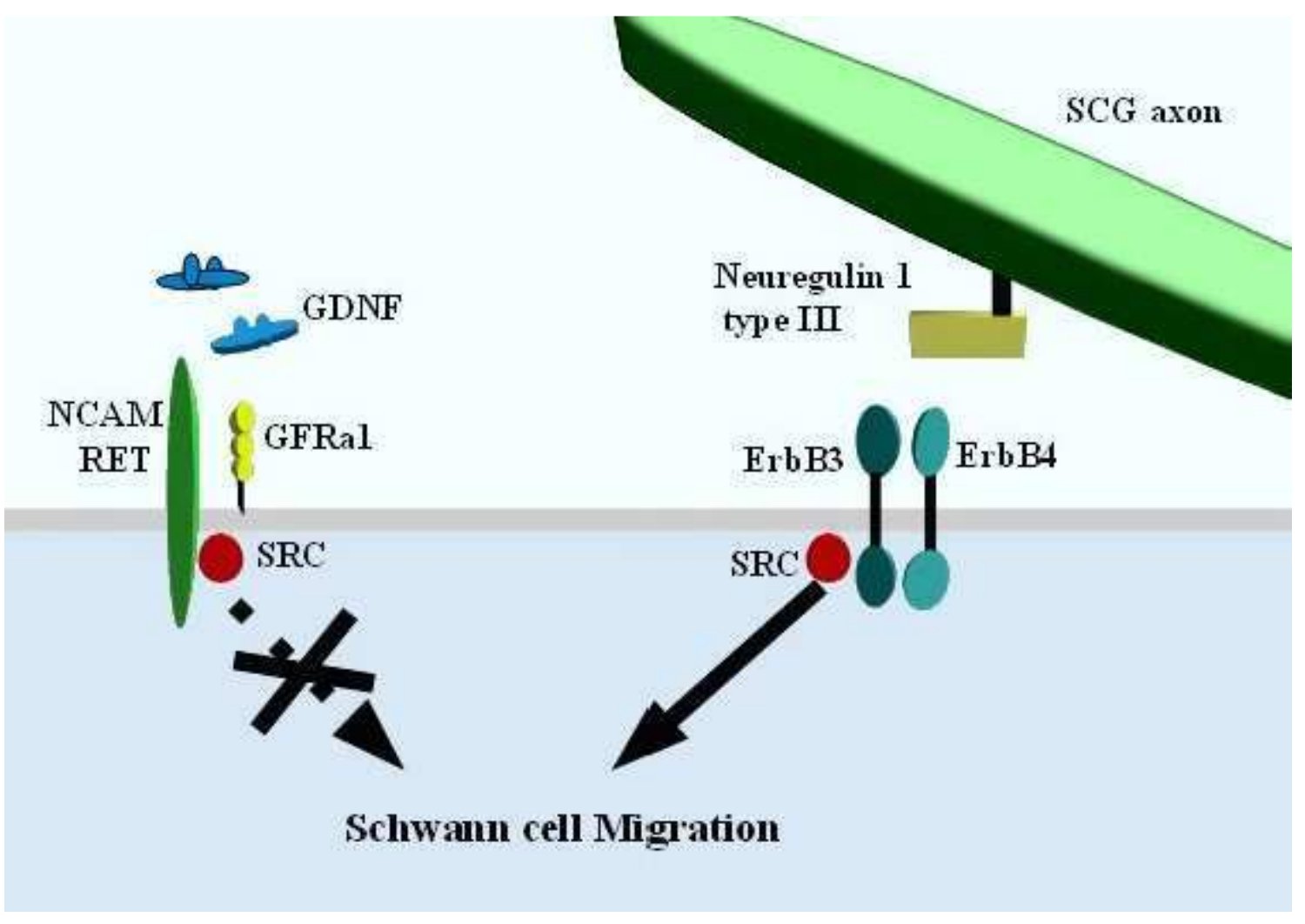

Abb. 2: Neuregulin-Signaling über den ErbB-Rezeptor

Die entscheidende Phase, in der Schwann-Zellen auf den Einfluss von Neuregulin angewiesen sind, liegt vermutlich zwischen dem Moment des Übergangs von einer Neuralleistenzelle in eine Schwann-Zell-Vorläuferzelle und dem Zeitpunkt vom Wandel der Schwann-Zell-Vorläuferzelle in eine myelinisierende bzw. nicht myelinisierende Schwann-Zelle. Sobald der Prozess der Differenzierung einer Neuralleistenzelle in eine Schwann-Zell-Vorläuferzelle stattgefunden hat, kommt dem 
Neuregulin-Signal-System viel mehr die Aufgabe zu, die Schwann-Zelle dazu zu bewegen, Myelinscheiden von adäquater Dicke zu formen, als die Rolle als Überlebenssignal zu übernehmen, wie intensiv diskutiert und spekuliert wird. Während der späten Entwicklung der Schwann-Zellen spielt NRG1 eine prominente Rolle als Wachstumsfaktor und Überlebenssignal (Garratt et al. 2000a); im adulten Organismus bilden dann Schwann-Zellen autokrin Faktoren, die das Überleben sichern, allerdings bleiben sie weiterhin fähig, auf NRG1 zu reagieren (Garratt et al. 2000b). Unterstrichen wird diese These durch die Beobachtung, dass NRG1-mRNA in auffallend hoher Menge in den Motoneuronen des Vorderhorns im Rückenmark und in den Spinalganglien-Neuronen exprimiert wird, folglich in den beiden „Hauptquellen“ von Axonen in embryonalen peripheren Nerven. In Neuralleisten-ZellKulturen inhibiert NRG1 die Entwicklung von Neuronen (Shah et al. 1994), eine Funktion, die indirekt zu sich potenzierender Gliogenese führen könnte (Jessen und Mirsky 2005). Diese Präsenz von Typ-III-NRG gewährleistet die Förderung und Aufrechterhaltung der Entwicklung von Schwann-Zell-Vorläufern und SchwannZellen. Wenngleich NRG1 die Hauptkomponente als Überlebens-und Differenzierungsfaktor ausmacht, agieren des Weiteren IGF, PDGF-BB und NT-3 als Synergisten bei der Entwicklung. NRG1-Proteine werden entlang des Axons transportiert und im nächsten Schritt axon-assoziierten Schwann-Zellen präsentiert, die durch ihre exprimierten Rezeptoren ErbB2 und ErbB3 mit NRG1 in Interaktion treten können (Lemke G 2001). Auf der anderen Seite tragen auch Schwann-Zellen zum Fortbestand der Neurone bei, indem sie Neurotrophine wie CNTF, GDNF, BDNF, LIF, PDGF, FGF und NT-3 produzieren. Durch die Bereitstellung eines wichtigen axonalen Signals, welches die Expansion der Schwann-ZellVorläuferzellen vermittelt, ist NRG1 verantwortlich für die Anpassung der Menge an Schwann-Zell-Vorläuferzellen. Festgestellt werden konnte bisher, dass in Mäusen mit Mutationen des Neuregulin1-Signalings die Mitwirkung der Neuralleistenzellen in kranialen Ganglien fehlt, was durch einen Defekt in der Migration der Neuralleistenzellen bedingt sein könnte (Garratt et al. 2000a). Des Weiteren konnte gezeigt werden, dass nach der stattgefundenen Trennung der Zellen von der dorsalen Neuralleiste Neuregulin 1 an der anschließenden Migration dieser Zellen über weite Distanzen entlang definierter Wege wesentlich beteiligt ist (Garratt et al. 
2000a). Neuregulin1 ist nicht nur in der frühen, sondern auch in der weiteren Entwicklung für die Migration von Schwann-Zellen von immenser Bedeutung.

\subsection{Fragestellung}

Wie dargestellt ist Neuregulin ein Kontrollprotein, das mit Rezeptoren der EGFRFamilie in Interaktion tritt. Vor allem pränatal nimmt es großen Einfluss auf die Entwicklung von Neuralleistenzellen und Schwann-Zellen.

Während der Entwicklung muss eine exakte Anzahl an Schwann-Zellen entlang des Axons gewährleistet sein, da sonst ein Mangel und eine damit verbundene Unterversorgung des Axons bei zu geringer und ein Tumor bei zu hoher Anzahl an Schwann-Zellen die Folge sein können. Aus diesem Grund müssen die Migration und Proliferation von Schwann-Zellen genau abgestimmt sein.

Es stellte sich die Frage, welche Signalwege für die Migration und die Proliferation von embryonalen Schwann-Zellen verantwortlich sind, und ob diese Signalwege miteinander in Interaktion treten oder eigenständig Einfluss auf die Entwicklung nehmen.

Die Fragestellung für die vorliegende Arbeit war, den Erb-Weg und damit Neuregulin1als Hauptregulator für die Schwann-Zell-Migration und die SchwannZell-Proliferation zu sichern. Da die Wirkungen des Neuregulin 1 abhängig von dem experimentellen Ansatz ausfallen, war es Ziel der vorliegenden Arbeit, die Versuche unter möglichst naturnahen Bedingungen in einer dreidimensionalen Kollagen-Kultur zu untersuchen und nicht Neuregulin einzusetzen, sondern mit dem Signalweg zu interferieren. 


\section{Material und Methoden}

\subsection{Material}

\subsubsection{Tiere}

NMRI (Naval Medical Research Institute)-Mäuse wurden von der zentralen tierexperimentellen Einrichtung der Universitätsmedizin Göttingen bezogen und an E16.5 präpariert. Der Morgen der Feststellung des Vaginalplugs galt dabei als Zeitpunkt E0.5.

\subsubsection{Zellkulturmedien und Zusätze}

DMEM (Dulbecco's modified Eagle medium), Neurobasal-Medium, 1x D-PBS, 50x B27, L-Glutamin 200mM, 100x Penicillin/Streptomycin/Neomycin (PSN) und 7,5\% Natriumbicarbonat wurden von Gibco/Invitrogen (Karlsruhe) bezogen. Gelatine als Hilfsmittel beim Aufziehen von Schnitten wurde von Roth (Karlsruhe) verwendet.

\subsubsection{Puffer und Lösungen für zellbiologische Arbeiten}

Die Herstellung von SCG-Medium, das zusammen mit NGF und entsprechenden Inhibitoren auf die präparierten Ganglien gegeben wurde, wurde durch die Gabe von

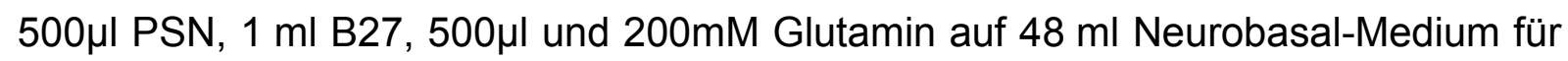
$50 \mathrm{ml}$ Medium ermöglicht. Es wurden 1,2 $\mu \mathrm{l}$ NGF auf $1 \mathrm{ml}$ SCG-Medium gegeben. Zur Erzeugung von $1 \mathrm{ml} \mathrm{CM}$ (konzentriertes Medium) wurden nacheinander 455 $\mu \mathrm{l}$

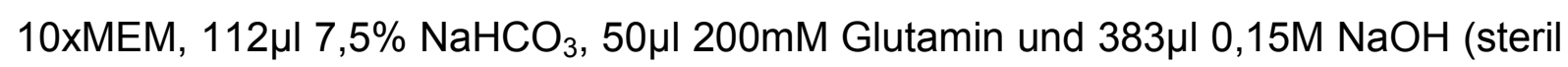
filtriert) vermischt. 


\subsubsection{Puffer und Lösungen für zytochemische Arbeiten}

10x PBS (Phosphat-buffered saline) wurde zusammengesetzt aus 1,38M Natriumchlorid, $27 \mathrm{mM}$ Kaliumchlorid, $81 \mathrm{mM}$ Dinatriumhydrogenphosphat und 14,7mM Kaliumdihydrogenphosphat.

4\% PFA (Paraformaldehyd) bestand aus 4\% w/v Paraformaldehyd in 1x PBS.

\subsubsection{Chemikalien}

Ethanol, Glycerin, Natriumhydroxid $(\mathrm{NaOH})$, Saccharose, Natriumchlorid $(\mathrm{NaCl})$ und Salzsäure $(\mathrm{HCl})$ wurden von der Firma Roth (Karlsruhe) und Eindeckmittel (Fluoromount-G) von Southern Biotechnology (Birmingham, AL, USA) erworben. Formaldehyd und Propidiumiodid wurden von Merck (Darmstadt) bezogen. Bromodeoxyuridin (BrdU), Normal Donkey Serum (NDS) und Triton-X 100 wurden von der Firma Fluka/Sigma (Taufkirchen) verwendet.

Normal Donkey Serum (NDS) wurde ebenfalls von der Firma Sigma (Taufkirchen), zum Teil auch von Dianova (Hamburg) bezogen.

Nystatin wurde von der Firma Gibco BRL (Heidelberg) verwendet.

\subsubsection{Inhibitoren}

PP2: Alexis: $5 \mu \mathrm{m}$. PP2 wurde in einer Endkonzentration von 1:100 auf SCG-Medium gegeben.

Erb-Inhibitor (EGFR/ErbB2/4-Inhibitor): Calbiochem: 0,8 $\mu \mathrm{g} / \mathrm{ml}$. Von einer bereits vorverdünnten Lösung von 1:25 des Erb-Inhibitors auf SCG-Medium/NGF wurden $10 \mu \mathrm{l}$ auf $1 \mathrm{ml}$ SCG-Medium/NGF gegeben, wobei $1,2 \mu \mathrm{l} \mathrm{NGF}$ in $1 \mathrm{ml}$ SCG-Medium gelöst waren. 


\subsubsection{Antikörper}

\begin{tabular}{|l|l|l|l|}
\hline $\begin{array}{l}\text { Primärantikörper } \\
\text { (Name und } \\
\text { Katalognummer) }\end{array}$ & Spezies und Typ & $\begin{array}{l}\text { Eingesetzte } \\
\text { Verdünnung }\end{array}$ & Firma \\
\hline $\begin{array}{l}\text { Rabbit-anti-TH } \\
\text { (AB152) }\end{array}$ & $\begin{array}{l}\text { Kaninchen } \\
\text { polyklonal }\end{array}$ & $1: 1000$ & $\begin{array}{l}\text { Millipore Chemicon, } \\
\text { Hampshire, UK }\end{array}$ \\
\hline Mouse-anti-S100B & Maus polyklonal & $1: 100$ & $\begin{array}{l}\text { Sigma-Aldrich, } \\
\text { München, D }\end{array}$ \\
\hline
\end{tabular}

\begin{tabular}{|l|l|l|l|}
\hline BrdU (ab 1893) & Schaf polyklonal & $1: 500$ & $\begin{array}{l}\text { Abcam, Cambridge, } \\
\text { UK }\end{array}$ \\
\hline \hline
\end{tabular}

\begin{tabular}{|l|l|l|}
\hline Sekundärantikörper & Eingesetze Verdünnung & Firma \\
\hline $\begin{array}{l}\text { Esel-anti-Kaninchen FITC } \\
(711-095-152)\end{array}$ & $1: 200$ & Dianova, Hamburg,D \\
\hline $\begin{array}{l}\text { Esel-anti-Maus Cy3 } \\
(715-165-151)\end{array}$ & $1: 200$ & Dianova, Hamburg,D \\
\hline $\begin{array}{l}\text { Esel-anti-Schaf Cy3 } \\
(713-165-147)\end{array}$ & $1: 200$ & Dianova, Hamburg,D \\
\hline
\end{tabular}


Material und Methoden

\subsubsection{Laborgeräte}

\begin{tabular}{|c|c|c|}
\hline Gerät & Typ & Firma \\
\hline Autoklav & Systec ELV 5050 & $\begin{array}{l}\text { Systec } \mathrm{GmbH} \text {, Wettenberg, } \\
\text { D }\end{array}$ \\
\hline Brutschrank & Biometra OV5 & Biometra, Göttingen, D \\
\hline Dialyseschlauch & $\begin{array}{l}\text { Spectropor MWCO 6000- } \\
8000 \mathrm{Da}\end{array}$ & $\begin{array}{l}\text { Roth } \mathrm{GmbH} \text {, Karlsruhe, } \\
\text { D }\end{array}$ \\
\hline Feinwaage & Sartorius 3716MP & Sartorius, Göttingen, D \\
\hline Live-Imager & LAS AF6000 & Leica, Solms, D \\
\hline Magnet-Rührer & RET basic & $\begin{array}{l}\text { Schütt Labortechnik, } \\
\text { Göttingen, D }\end{array}$ \\
\hline Mikroliter-Pipetten & PipettmanP & Gilson, Middleton, USA \\
\hline Präzisionswaage & Sartorius 1602MP & Sartorius, Göttingen, D \\
\hline Rollschüttler & CAT RM5 & NeoLab, Heidelberg, D \\
\hline Rundschüttler & KS 250 basic IKA & $\begin{array}{ll}\text { Schütt, Labortechnik, } \\
\text { Göttingen, D }\end{array}$ \\
\hline Sterilbank & Heraeus HeraSafe & $\begin{array}{l}\text { Kendro Laboratory GmbH, } \\
\text { Langenselbold, D }\end{array}$ \\
\hline Vortexer & VORTEX Genie2 G560 & $\begin{array}{l}\text { Scientific industries Inc., } \\
\text { Bohemia, NY, USA }\end{array}$ \\
\hline Zentrifugen & $\begin{array}{l}\text { Centrifuge5415D } \\
\text { Centrifuge5417 } \\
\text { Sorval EvolutionRC }\end{array}$ & $\begin{array}{l}\text { Eppendorf, Hamburg, D } \\
\text { Eppendorf, Hamburg, D } \\
\text { Kendro Laboratory GmbH, } \\
\text { Langenselbold, D }\end{array}$ \\
\hline
\end{tabular}




\subsubsection{Verbrauchsmaterialien}

\begin{tabular}{|c|c|}
\hline Deckgläschen (Durchmesser 12mm) & Menzel-Gläser, Braunschweig, D \\
\hline $\begin{array}{l}\text { Mikropipettenspitzen } \quad(10 \mu \mathrm{l}, \quad 200 \mu \mathrm{l}, \\
1000 \mu \mathrm{l})\end{array}$ & $\begin{array}{l}\text { Eppendorf, Hamburg; Brand, Wertheim } \\
\text { oder Sarstedt, Nümbrecht, D }\end{array}$ \\
\hline $\begin{array}{l}\text { Multiwellplatten für die Zellkultur (96 } \\
\text { Schalen, } \\
48 \text { Schalen) }\end{array}$ & Nunc, Langenselbold, D \\
\hline Objektträger & Roth, Karlsruhe, D \\
\hline Pipettenspitzen & Sarstedt, Nümbrecht, D \\
\hline Plastik-Pipetten (5 ml, 10 ml, 25 ml) & Costar, Schiphol-Rijk, Niederlande \\
\hline Reaktionsgefäße & $\begin{array}{l}\text { Eppendorf, Hamburg und Sarstedt, } \\
\text { Nümbrecht, D }\end{array}$ \\
\hline
\end{tabular}

\subsubsection{Software}

Axio Vision Zeiss, Jena

LAS AF Lite Leica, Solms

Gimp 2

Image J National Institute of Health, USA

AlphaEase 4.0 Alpha innotech corporation, San Leandro, CA, USA 


\subsection{Methoden}

\subsubsection{Herstellung des Kollagens}

Die Herstellung des Kollagens erfolgte unter sterilen Gegebenheiten.

Es wurden benötigt:

Sezierbesteck, Klemmen, Aqua dest. (steril filtriert), Handschuhe, 2×2000-mlErlenmeyer-Kolben, 500-ml-Flaschen, Petrischalen, Dialysierschläuche, 2 Bechergläser, spezielle Zentrifugengläser mit Deckel (autoklaviert);

Schwänze (eingefroren) von 6-9 Monate alten Ratten.

Die weiteren Angaben beziehen sich auf die Herstellung von Kollagen aus 4 Rattenschwänzen:

Zunächst wurden die Rattenschwänze für 15 Minuten in Alkohol (95\%) aufgetaut. Eine Petrischale wurde mit Aqua dest. gefüllt, und in eine weitere, trockene Petrischale wurde ein Rattenschwanz aufgelegt. Dieser wurde dann an seinem dickeren Ende mit zwei Klemmen eingeklemmt und anschließend mit einer weiteren Klemme gefasst und gegeneinander gedreht. Während der Schwanz langsam auseinander gezogen wurde, konnten die Silberfäden (Kollagenfasern) mit einer sterilen Schere abgeschnitten werden. Im Anschluss daran wurden die Kollagenfasern für 30 Minuten in Aqua dest., zusammen mit Nystatin (Gibco, $5 \mathrm{ml} / 100 \mathrm{ml}$ Aqua dest.), gegeben, um die Fasern von möglichen Pilzen zu befreien. Auf diese Art wurden der gesamte Schwanz und auch die übrigen Schwänze präpariert. Die somit erhaltenen Kollagenfäden wurden dann mit zwei feinen Pinzetten auseinander gezogen.

Im Anschluss daran wurden die Fasern mit einer Pinzette aus dem Aqua dest. in eine Flasche mit Essigsäure überführt (7,5 $\mathrm{ml}$ 100\% Essigsäure auf $250 \mathrm{ml}$ Aqua dest.). In diesem Zustand wurden die Kollagenfasern für vier Tage im Kühlschrank $\left(4^{\circ} \mathrm{C}\right)$ aufbewahrt und zwischendurch geschwenkt.

Nach vier Tagen wurden drei Dialysierschläuche auf ca. $50 \mathrm{~cm}$ Länge zugeschnitten, locker aufgerollt und im Becherglas in Aqua dest. gewässert, in der Folge mehrfach gekocht, und nach jedem Kochvorgang das Aqua dest. erneuert, um die Weichmacher zu entfernen. Im Anschluss daran wurde autoklaviert. 


\section{Material und Methoden}

Die Kollagenlösung wurde unter der Sterilbank in Spezialzentrifugenröhrchen (Pipettus, sterile, neue Plastikpipette) eingefüllt. (Schütt/Fa. Sorvall $30 \mathrm{ml}$ Oak RIDGE Bottle Kat. Nr. 03719 non sealing caps PC). Nach diesem Vorgang wurde 20 Minuten zentrifugiert (bei $19000 \mathrm{U} / \mathrm{min}$ ), bei einer Temperatur von $0^{\circ} \mathrm{C}$.

Es wurden 2 Liter Aqua dest. steril filtriert, während unter der Sterilbank Filter auf $500 \mathrm{ml}$ Glasflaschen gesetzt, die Pumpe angestellt, das Ansatzstück auf den Pumpenschlauch gesetzt, die Deckel vom Filter genommen und steriles Aqua dest. in 2000-ml-Erlenmeyer-Kolben gefüllt wurden.

Darauf wurden $20 \mathrm{ml} 10 \mathrm{x}$ MEM (gekühlt, $4^{\circ} \mathrm{C}$ ) gegeben. Anschließend wurden langsam $10 \mathrm{ml} 4^{\circ} \mathrm{C}$ gekühltes $7,5 \% \mathrm{NaHCO}_{3}$ (Seromed) hinzugegeben und mit einer Pipette verrührt. Im Anschluss daran wurde eine Probe entnommen, um den pH gegebenenfalls durch Zugabe von Bicarbonat auf pH 7,2-7,4 einzustellen.

\subsubsection{Dialysieren}

Zum Dialysieren musste der Überstand aus den zentrifugierten Röhrchen in ein Becherglas gegossen werden, und, falls die Fasern nicht am Boden hafteten, musste abpipettiert werden. Unter Verwendung von sterilen Handschuhen wurden die Dialyseschläuche nacheinander entnommen und über der sterilen Aluminiumfolie wurde das Ende zugeknotet.

Hinterher wurde das Aqua dest. abgestreift, die Schlauchöffnung oben auseinander gefaltet und die Kollagenlösung auf ein ca. $15 \mathrm{~cm}$ langes Schlauchstück eingefüllt und zugeknotet.

Die Schlauchstücke wurden dann in Dialysierflüssigkeit in den Erlenmeyerkolben gehängt und ein evtl. überhängendes Ende mit Klebestreifen fixiert. Dieses Verfahren wurde bei allen drei Schlauchstücken angewandt, und in diesem Zustand mit Aluminiumfolie verschlossen für 24 Stunden im Kühlschrank bei $4^{\circ} \mathrm{C}$ stehen gelassen. Nach 24 Stunden wurde wieder der pH-Wert gemessen, und bei zu alkalischem Wert mit $\mathrm{HCl}$ auf 4,0 eingestellt; falls der $\mathrm{pH}$ zu niedrig war, wurde tröpfchenweise Bicarbonat $(1 \mathrm{ml})$ gegeben. 


\section{Material und Methoden}

Die Schläuche wurden erneut für 24 Stunden in die Lösung gehängt und im Kühlschrank aufbewahrt. Im Anschluss wurde dann ein 500-ml-Becherglas unter der Sterilbank bereitgestellt, sowie ein steriles Skalpell und drei sterile 100-ml-Flaschen.

Die Schläuche wurden nacheinander entnommen und über dem Becherglas unten mit dem Skalpell angeritzt, sodass das Kollagen in dem Becherglas aufgefangen werden konnte. Schließlich wurde dann die Kollagenmenge auf die drei sterilen 100-ml-Flaschen verteilt.

\subsubsection{Herstellung des SCG-Mediums}

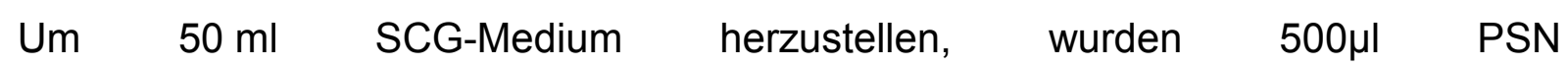

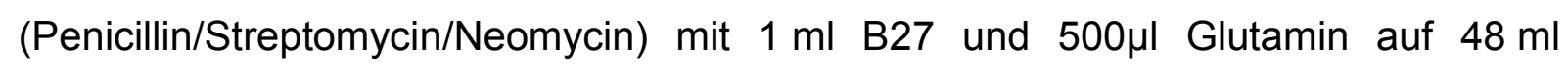
Neurobasal-Medium gegeben.

\subsubsection{Herstellung des konzentrierten Mediums (CM)}

Zur Herstellung von $1 \mathrm{ml} \mathrm{CM}$ wurden nacheinander auf $455 \mu \mathrm{l}$ 10x Medium, 50 $\mu \mathrm{l}$ Glutamin, $383 \mu \mathrm{l} 1 \mathrm{~N} \mathrm{NaOH}$ (steril filtriert) und $112 \mu \mathrm{l} \mathrm{NaHCO}_{3}$ pipettiert und danach mittels Vortexer vermischt.

\subsubsection{Präparation der Embryonen}

Für die Präparation der primären Zellen aus dem Ganglion cervicale superius wurden Embryonen einer zeitlich verpaarten Maus am Trächtigkeitstag E 16.5 verwendet. Das Muttertier wurde durch zervikale Dislokation getötet und die Embryonen vorsichtig mit einer Pinzette entnommen, in ein mit 1x DPBS gefülltes Gefäß überführt und auf Eis gekühlt. Zur Präparation wurde jeweils ein Embryo mit dem Rücken auf eine sterile weiche Unterlage gelegt und mittels Spritzennadeln fixiert. Durch Überstreckung des Kopfes lag der zu präparierende Bereich frei und war gut zugänglich. Die Präparation erfolgte unter dem Mikroskop, indem mit zwei Pinzetten 


\section{Material und Methoden}

das SCG freipräpariert wurde und nach Entnahme sofort in ein Gefäß mit DPBS überführt wurde. Nach der Präparation aller Embryonen eines Wurfs konnten die SCGs unter Verwendung von zwei dünnen Spritzen aus dem DPBS jeweils in eine Schale einer 96-Well-Platte gegeben werden. In jeder einzelnen Schale war zuvor das Kollagengel aufgetragen, das aus einer Mischung von $800 \mu \mathrm{l} \mathrm{Kollagen} \mathrm{auf} 210 \mu \mathrm{l}$ CM bestand und pro Schale $50 \mu$ l beinhaltete. Danach wurde die Well-Platte für zwei Stunden bei $37^{\circ} \mathrm{C}$ inkubiert.

Nach zwei Stunden wurde jede Schale mit $50 \mu \mathrm{l}$ SCG-Medium und $100 \mu \mathrm{l}$ NGFMedium behandelt. Das NGF-Medium wurde zusammengesetzt aus $1,2 \mu \mathrm{l}$ NGF auf $1 \mathrm{ml} \mathrm{SCG-Medium.}$

Die Well-Platte wurde dann wieder bei $37^{\circ} \mathrm{C}$ inkubiert, die Anzahl der Tage der Inkubation richtete sich nach der Versuchsreihe.

Bei einer direkten Behandlung mit dem Erb-Inhibitor wurden gleichermaßen $50 \mathrm{ml}$ des SCG-Mediums auf eine Schale gegeben, in Kombination mit 100 $\mu$ l des ErbInhibitor-Mediums. Dieses wurde vorverdünnt, indem $4 \mu \mathrm{l}$ des Erb-Inhibitors auf $100 \mu \mathrm{l}$ SCG-Medium gegeben wurden und davon wiederum $10 \mu \mathrm{l}$ auf $1 \mathrm{ml}$ SCG-Medium,

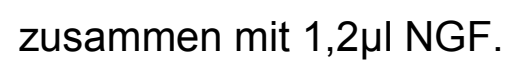

In der Versuchsreihe, in der mit BrdU behandelt wurde, erfolgte diese Behandlung zwischen dem achten und zehnten Tag nach Explantation, nachdem am vierten oder fünften Tag ein Mediumwechsel vorgenommen worden war. Bromodesoxyuridin (BrdU) wird als Basenanalogon während der S-Phase in die DNA von teilungsaktiven Zellen eingebaut und kann später immunzytochemisch nachgewiesen werden. Für die einfache BrdU-Markierung zur Bestimmung des Anteils proliferierender Zellen

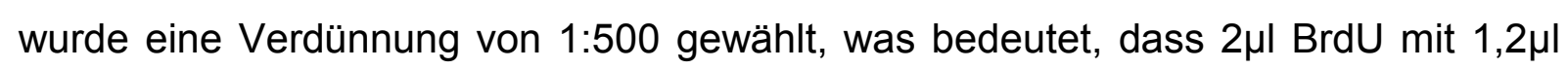
NGF auf $1 \mathrm{ml} \mathrm{SCG-Medium} \mathrm{gegeben} \mathrm{wurden} \mathrm{und} \mathrm{die} \mathrm{einzelne} \mathrm{Schale} \mathrm{dann} \mathrm{mit} \mathrm{50 \mu l}$

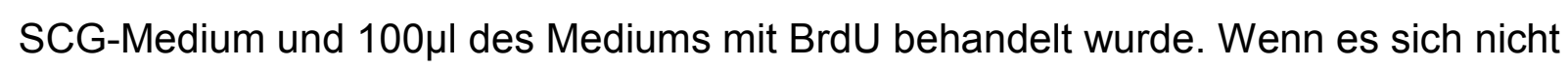
um die Kontrollgruppe, sondern die mit Erb-Inhibitor behandelte Gruppe handelte, mussten zusätzlich noch 10ul des 1:25 vorverdünnten Erb-Inhibitors hinzu gegeben werden und, um bei einer Gesamtmenge von $100 \mu$ zu bleiben, $10 \mu l$ weniger SCGMedium verwendet werden.

Je nach Versuchsreihe wurde die Behandlung nach fünf bis sieben Tagen oder nach neun bis zehn Tagen gestoppt. Bei der Fixierung nach fünf bis sieben Tagen handelt es sich um die Versuchsreihe, in der direkt mit PP2 oder dem Erb-Inhibitor behandelt 


\section{Material und Methoden}

wurde, bei der Fixierung nach neun bis zehn Tagen um die Experimente, bei denen erst nach einigen Tagen behandelt wurde. Handelte es sich um einen Versuch, in dem es zur Anwendung von BrdU kam, wurde immer genau sechs Stunden nach BrdU-Gabe fixiert, was insgesamt auf den neunten bis zehnten Tag nach Explantation fiel. Die Fixierung erfolgte, indem mit einer Pipette das Medium aus den Schalen abgenommen wurde und reichlich PFA (4\%) darauf gegeben wurde. Die Well-Platte wurde dann für 24 Stunden bei $4^{\circ} \mathrm{C}$ gelagert. Nach diesem Zeitraum wurde wieder mittels Pipette das PFA abgenommen und PBS auf die im Gel liegenden Ganglien gegeben.

\subsubsection{Anfertigung von Schnitten}

Um Schnitte für die Immunzytochemie anzufertigen, wurde das PBS von den Ganglien abgenommen, und jedes einzelne Ganglion wurde anhand von Kugelstopfern in eine Schale einer 24-Well-Platte überführt und zwischen 5 und 24 Stunden in einer Saccharose-Lösung entweder auf dem Schüttler oder bei $4^{\circ} \mathrm{C}$ gelagert. Wichtig war, dass die Ganglien in der Saccharose-Lösung auf den Boden der Schale abgesunken waren, was z.T. schon nach 5 Stunden der Fall war. Die Saccharose-Lösung setzte sich zusammen aus 3 Gramm Saccharose auf $10 \mathrm{ml}$ PBS und wurde ebenso benutzt, um die Ganglien beim Schneiden auf eine aus dieser Lösung bestehenden Unterlage, die dann gefroren war, zu befestigen.

Zum Schneiden wurde ein Schneidegerät der Firma Reichert-Jung (Frigomobil) benutzt. Zunächst wurde aus der Saccharose-Lösung ein Turm unter Verwendung einer Einmal-Pipette auf ein zugeschnittenes Stück Filterpapier pipettiert und gewartet, bis dieser gefror. Sobald dies der Fall war, wurde die Kühlung komplett ausgeschaltet und die gefrorene Saccharose kurz mit dem Finger angetaut. Anschließend wurde wieder die Kühlung 1 angeschaltet und ein Ganglion mit Hilfe eines Pinsels auf einen Objektträger befördert und dieser dann verkehrt herum über die gefrorene Saccharose gehalten, sodass das anheftende Ganglion an der Saccharose festfrieren konnte. Beim Schneiden wurde die Kühlung 2 angestellt. Es wurden immer $120 \mu \mathrm{m}$ dicke Schnitte hergestellt mit Ausnahme eines Explantates, das mit S100B gefärbt wurde, bei denen $80-\mu m$-Schnitte angefertigt wurden. Die 


\section{Material und Methoden}

Schnitte wurden wieder anhand des Pinsels vom Messer in eine 24-Well-Platte überführt, wo sie wiederum in PBS gelagert wurden.

\subsubsection{Immunzytochemie}

Zur Darstellung von Axonen, Zellkernen und proliferierenden Zellen wurde die Immunzytochemie angewandt. Dazu wurden die Schnitte mit Hilfe einer Einmal-

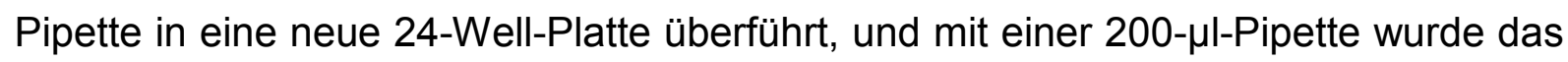
PBS abgenommen.

Handelte es sich um Ganglien, die mit BrdU behandelt worden waren, wurde vor Gabe der Blocklösung nach abcam-Schema vorgegangen. Für die Detektion von BrdU wurden die Schnitte zunächst für 10 Minuten in $1 \mathrm{~N} \mathrm{HCl}$ auf Eis inkubiert, um die DNA-Struktur aufzubrechen. Anschließend wurden die Schnitte in $2 \mathrm{~N} \mathrm{HCl}$ für 10 Minuten bei Raumtemperatur, und dann bei $37^{\circ} \mathrm{C}$ inkubiert. Danach wurden die Zellen für 12 Minuten in Boratpuffer (150mM H $\left.\mathrm{H}_{3} \mathrm{BO}_{3}, \mathrm{pH} 8,4\right)$ neutralisiert.

Für die Blockierung unspezifischer Bindungen wurde für 1,5 bis 2 Stunden eine Blocklösung auf die Ganglien gegeben, die sich aus 10\% NDS (Normal Donkey Serum) und $2 \%$ Triton X-100 in PBS zusammensetzte. Die Inkubation mit den Primärantikörpern, verdünnt in der Blocklösung, erfolgte über Nacht bei $4^{\circ} \mathrm{C}$. Im Folgenden wurden die Schnitte dreimal für 10 Minuten mit PBS gewaschen und anschließend für 2 Stunden mit den jeweiligen Sekundärantikörpern verdünnt in Blocklösung bei Raumtemperatur auf dem Schüttler inkubiert. Ab dem Zeitpunkt, an dem die Sekundärantikörper angewandt wurden, musste die Well-Platte mittels Aluminiumfolie vor Licht geschützt werden. Nach erneutem dreimaligen Waschen mit PBS wurden die Schnitte auf Objektträger aufgezogen. Dabei wurden die Schnitte zuvor in eine Lösung von Gelatine und Alkohol gegeben, um sicherzustellen, dass sie am Objektträger haften würden. Zur Herstellung dieser Lösung wurde $1 \mathrm{Gramm}$ Gelatine auf $120 \mathrm{ml}$ Aqua dest. gegeben und unter Rühren auf ca. $40^{\circ} \mathrm{C}$ erhitzt. Hinterher wurden darauf $80 \mathrm{ml}$ vergälltes Ethanol (80\%) gegeben.

Die Schnitte wurden dann bei $37^{\circ} \mathrm{C}$ über Nacht inkubiert, und am nächsten Tag wurde mittels Pipette DAPI im Verhältnis 1:1000 (in PBS) zugesetzt, für 5 Minuten inkubiert und anschließend für mehrere Minuten mit PBS und Wasser gewaschen. In 
der Folge konnten die Schnitte dann eingedeckt werden, wozu Fluoromount-G Eindeckmedium benutzt wurde.

\subsubsection{Fluoreszenzmikroskopie}

Die Bilder der fluoreszierenden Antikörper-Markierungen wurden an einem Axio Imager Z1 Mikroskop (Carl Zeiss AG, Jena) mit angeschlossener Digitalkamera (AxioCamMR Kamera, Carl Zeiss AG, Jena) aufgenommen. Die Anregungs (Ex)-und Emissionswellenlängen (BA) betrugen für den DAPI-Filter: Ex 340-380, BA 435-485, für den FITC-Filter: Ex 465-495, BA 515-555 und für den Cy3-Filter: 510-560, BA 590 (alle Angaben in $\mathrm{nm}$ ).

Die Fotos wurden sowohl in 20-facher als auch in 40-facher Vergrößerung aufgenommen.

\subsubsection{Messung des Abstandes Kern-Axonende}

Insgesamt wurden in dieser Arbeit sechs Explantate jeweils zur Hälfte unmittelbar nach Explantation mit PP2 behandelt, davon drei zusätzlich mit BrdU. Im Rahmen der Behandlung mit dem Erb-Inhibitor wurden sieben Explantate unmittelbar mit dem Erb-Inhibitor behandelt und fünf nach einigen Tagen, diese jeweils auch mit BrdU. Pro Explantat wurden zwischen sechzig und zweihundert Werte gemessen.

Um auszuwerten, wie groß der Abstand zwischen dem letzten, distal gelegenen Kern und dem Ende des Axons war, wurden zunächst die Aufnahmen der verschiedenen Kanäle übereinander gelagert, in diesem Falle der DAPI-Kanal und der TH-Kanal, der durch den FITC-Filter die angefärbten Axone darstellte. Die Überlagerung war mit Hilfe der Software Gimp2 möglich, das Ausmessen der Abstände unter Verwendung des Programms Image J (National Institute of Health, USA).

Die Messung erfolgte in Pixel, die im Nachhinein in Mikrometer umgerechnet wurde und sich je nach Vergrößerung des Bildes richtete, sodass sich vergleichbare Ergebnisse ergaben. So wurde bei einer 20-fachen Vergrößerung die Pixelzahl mit dem Faktor 2/6 multipliziert; bei der 40-fachen Vergrößerung mit dem Faktor 1/6. 


\subsubsection{Quantifizierung der Zellen}

Die Auszählung der markierten Zellen (DAPI und BrdU) erfolgte manuell anhand der AlphaEaseFC ${ }^{\mathrm{TM}}$ Software (Alpha innotech corporation, San Leandro, CA, USA).

\subsubsection{Live Cell Imaging}

Mit der Methode des Live Cell Imaging lassen sich mikroskopische ZeitrafferAufnahmen sich bewegender und sich teilender Zellen anfertigen. Die Zellkulturschalen werden während der Beobachtungsphase in einer Inkubationskammer begast und temperiert $\left(37,2^{\circ} \mathrm{C}\right)$. Ein Computer steuert in dieser Zeit eine Digitalkamera, die in festen Intervallen eine Aufnahme macht. Eine Abfolge dieser Bilder ergibt einen Zeitrafferfilm, in dem die Zellbewegung sichtbar wird.

Im Gegensatz zu den statischen Momentaufnahmen, die mit fixierten Präparaten produziert werden, erlaubt es das Live Cell Imaging, dynamische Prozesse unter realen Bedingungen zeitabhängig zu betrachten. Durch die gleichzeitige Visualisierung mehrerer Parameter im intakten nativen System der lebenden Zelle können verschiedenste zelluläre Abläufe umfassender und detaillierter untersucht werden. Die digitale Fluoreszenzmikroskopie dient somit als automatisierbares Verfahren zur Beobachtung von Zellbewegung, -wachstum, -teilung, aber auch vom Zellsterben - visualisierbar durch charakteristische Veränderungen in der Zellmorphologie. 


\section{Ergebnisse}

\subsection{Assay zur Analyse der Schwann-Zell-Migration}

In Veröffentlichungen im Zusammenhang mit der Erforschung von Migration und Proliferation von Schwann-Zellen sind verschiedene Methoden angewandt worden, um die Wanderung der Schwann-Zellen zu analysieren;

bei Meintanis et al. (2001) kamen Scratch assays zur Anwendung, bei Yamauchi et al. (2008) wurden Boyden assays verwendet und bei Paratcha et al. (2003) kamen Emigration assays zum Einsatz. Obwohl diese Modelle häufig eingesetzt werden, ist daran zu bemängeln, dass den Schwann-Zellen in diesen Experimenten ihr natürliches Habitat, nämlich die Nervenfaser, fehlt. Aus diesem Grunde ist der informative Wert dieser Versuche limitiert.

In der vorliegenden Arbeit hingegen wurde das Ganglion cervicale superius bei der Präparation entnommen, sodass die Schwann-Zellen gleichzeitig mit dem Auswachsen der Axone an innen entlang wandern konnten und sich zu jedem Zeitpunkt der Entwicklung in einer in der Natur vorkommenden vergleichbaren Situation befanden.

Es wurden embryonale Explantate aus dem Ganglion cervicale superius (SCG) behandelt, die sich in einer dreidimensionalen Kollagenmatrix entfaltet hatten. Unter diesen Gegebenheiten und Behandlung mit NGF konnten Axone aus dem Ganglion auswachsen und Schwann-Zellen an diesen Axonen entlang in die Peripherie migrieren.

Ein solcher Aufbau reflektiert die in-vivo-Situation auswachsender Axone mit nachfolgender Schwann-Zell-Migration in einem weit größeren Ausmaß als all die bisher eingesetzten Systeme für die Erforschung von Schwann-Zell-Migration in der Maus oder der Ratte.

Schwann-Zellen sind während der Entwicklung stark vom Neuregulin-Signaling beeinflusst, vor allem bezüglich ihrer Migration entlang der Axone. Werden diese Signalwege blockiert, sei es durch Darstellung der Migration von Schwann-Zellen an Neuregulin-Knock-out-Mäusen (Heermann et al.2011), oder unter Anwendung des 


\section{Ergebnisse}

Erb-Inhibitors, der die Bindung des Neuregulins an seinen Rezeptor verhindert, wird eine signifikante Verminderung der Migration von Schwann-Zellen festgestellt.

Um zu diesem Ergebnis zu gelangen, wurde der Erb-Inhibitor gewählt, ein Inhibitor am ErbB-Rezeptor, der unter natürlichen Umständen Neuregulin bindet.

Später wurde diese Versuchsreihe erweitert, indem der Proliferationsmarker BrdU eingesetzt wurde, um zusätzliche Informationen über die Proliferation der SchwannZellen in Abhängigkeit vom Einsatz des Erb-Inhibitors darzustellen. BrdU ist ein Marker, der Zellen färbt, die gerade im Begriff sind, sich zu teilen. Diese Methode wurde angewandt, um Aufschluss darüber zu erhalten, ob der Erb-Inhibitor nur die Migration der Schwann-Zellen beeinflusst, oder auch die Proliferation. BrdU wurde nach 9 bzw. 10 Tagen für 6 Stunden gegeben, sodass der Unterschied im Proliferationsverhalten der Schwann-Zellen unter normalen Umständen und während der Behandlung mit dem Erb-Inhibitor, der nach 4 bzw. 5 Tagen hinzugefügt worden war, hervorgehoben werden konnte.

\subsubsection{Charakterisierung der migrierenden Zellen als Schwann-Zellen}

S-100B ist ein Calcium-bindendes Protein mit niedriger Molekülmasse, welches von Schwann-Zellen exprimiert wird.

Im ersten Experiment dieser Arbeit wurden ein Maus-anti-S-100B als Primärantikörper und ein Esel-anti-Maus Cy3 eingesetzt. Auf diese Weise konnten Zellen dargestellt werden, die S-100B-positiv waren, demzufolge Schwann-Zellen. Da immer gleichzeitig mit DAPI gefärbt wurde, konnte dargestellt werden, dass die S100-positiven Zellen alle ebenfalls DAPI-positiv waren (siehe Abb. 3). Somit konnte, vor allem im Hinblick auf weitere Experimente, sichergestellt werden, dass es sich bei den DAPI-positiven Zellen, die am Axon lagen, um Schwann-Zellen handelte. 


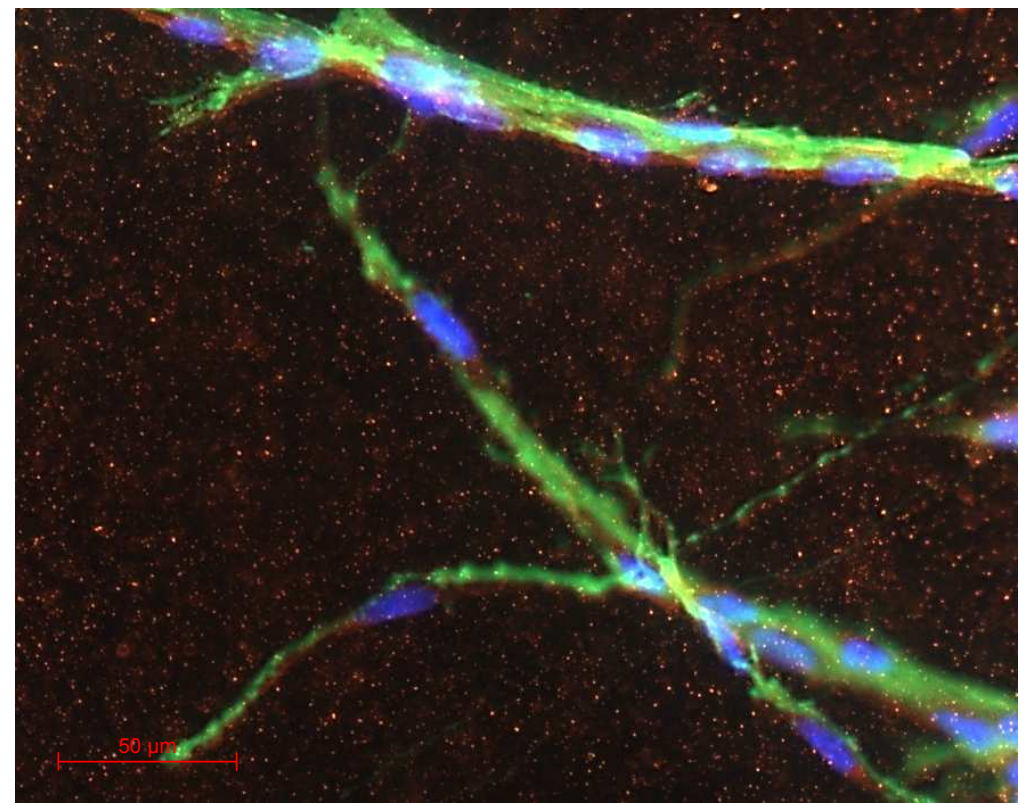

Abb. 3: Aufnahme in 40-facher Vergrößerung. Färbung mit S100 (rot), DAPI (blau), und TH (grün) zur Darstellung von Schwann-Zell-Kernen am Axon

\subsubsection{Erb-Inhibitor-Behandlung Explantation}

Die Explantate wurden unmittelbar nach Präparation für zwei Stunden in den Inkubator gegeben. Nach diesen zwei Stunden wurde mit der Behandlung begonnen; die eine Hälfte der Explantate diente als Kontrollgruppe und wurde mit SCG-Medium und NGF behandelt. Die andere Hälfte wurde zusätzlich mit Erb-Inhibitor behandelt. In den verschiedenen Experimenten dauerte die Behandlung jeweils zwischen fünf und sieben Tagen, bei lediglich einem einzigen Explantat wurde ein Mediumwechsel am 5. Tag mit anschließender Fixierung am 9. Tag vorgenommen.

Um das unterschiedliche Verhalten der Schwann-Zellen zu untersuchen, wurden Kryoschnitte $(120 \mu \mathrm{m})$ angefertigt, die dann mit TH und DAPI gefärbt wurden.

Die Analyse unter dem Fluoreszenzmikroskop zeigte oftmals schon, dass die DAPIpositiven Zellen, dementsprechend die Kerne der Schwann-Zellen, in der Kontrollgruppe bis weit in die Peripherie entlang der gegen TH gefärbten Axone gewandert waren. Auch die Axone waren vom Ganglion aus weit ausgewachsen. 


\section{Ergebnisse}

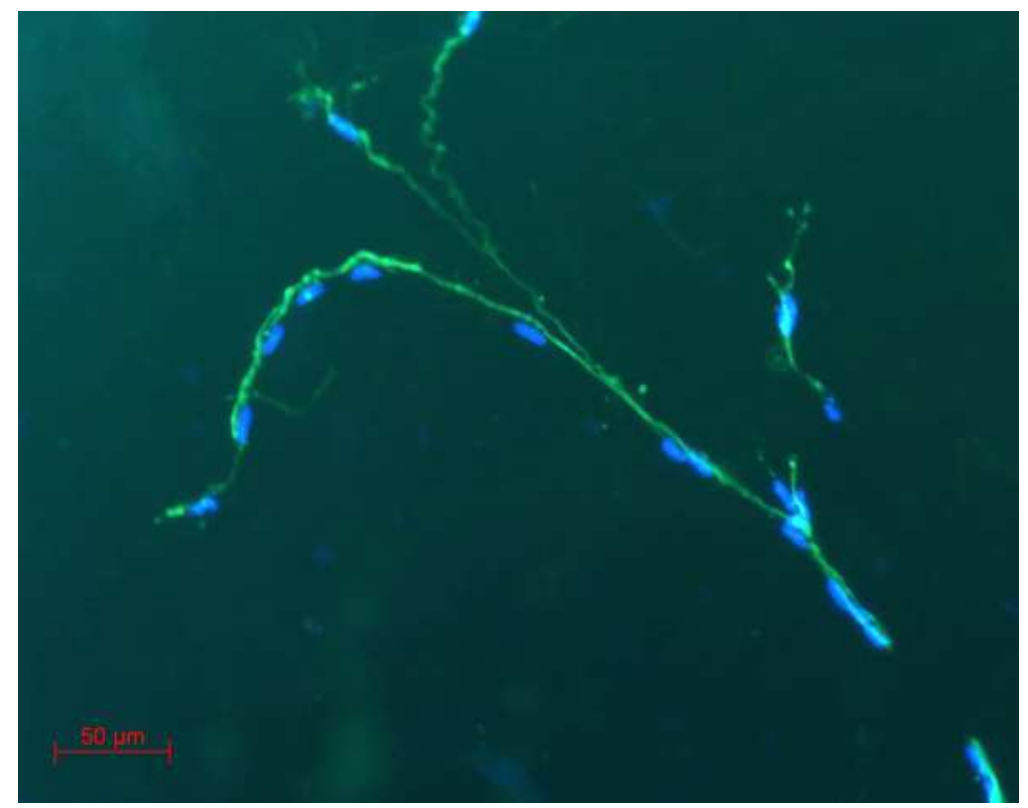

Abb. 4: Aufnahme in 20-facher Vergrößerung aus der Kontrollgruppe nach direkter Erb-Inhibitor-Behandlung. Dargestellt sind die am Axon liegenden Schwann-Zellen, deren Kerne mit DAPI (blau) angefärbt wurden.

In Abbildung 4 ist ein repräsentatives Bild des Verhaltens der Schwann-Zellen in der Kontrollgruppe dargestellt. Deutlich zu erkennen sind die bis weit in die Peripherie gewanderten Schwann-Zell-Kerne, die dem Axon direkt anliegen.

In einigen Explantaten waren Hauptäste des Axons, die sich in mehrere Endäste verzweigen, zu erkennen. An allen diesen Endästen wandern weiterhin SchwannZellen entlang und sind auch bis zum Ende eines jeden Astes präsent. Falls der letzte Kern vorm Axonende vor einer Aufgabelung verschiedener Zweige lag, wurden von diesem Kern ausgehend mehrere Messungen vorgenommen, jeweils bis zum Ende eines jeden Astes. Im Vergleich zu den Ganglien, die mit dem Erb-Inhibitor behandelt wurden, sind in der Kontrollgruppe der nur mit NGF behandelten Ganglien sehr viele DAPI-positive Zellen entlang der Axone zu erkennen. Nicht nur der letzte Kern liegt deutlich näher am Axonende als bei den Erb-behandelten Ganglien, auch die absolute Zahl der Schwann-Zellen, die aus dem Ganglion gewandert sind oder sich auf dem Weg entlang des Axons befanden, ist größer.

Der Nachweis für diese Feststellung wurde in einem weiteren Experiment im Rahmen der Auswertung der BrdU-gefärbten Explantate erbracht. An jener Stelle wurden die DAPI-positiven Zellen in Verhältnis gesetzt zu den BrdU-positiven Zellen, 


\section{Ergebnisse}

dementsprechend das Verhältnis aller Zellen zu den sich in Teilung befindenden Zellen. Die Ergebnisse stimmen mit denjenigen, die mittels der Fotos gezeigt werden konnten, sowie denjenigen, die anhand des Live Cell Imaging (Heermann et al. 2011) hervorgebracht wurden, überein.

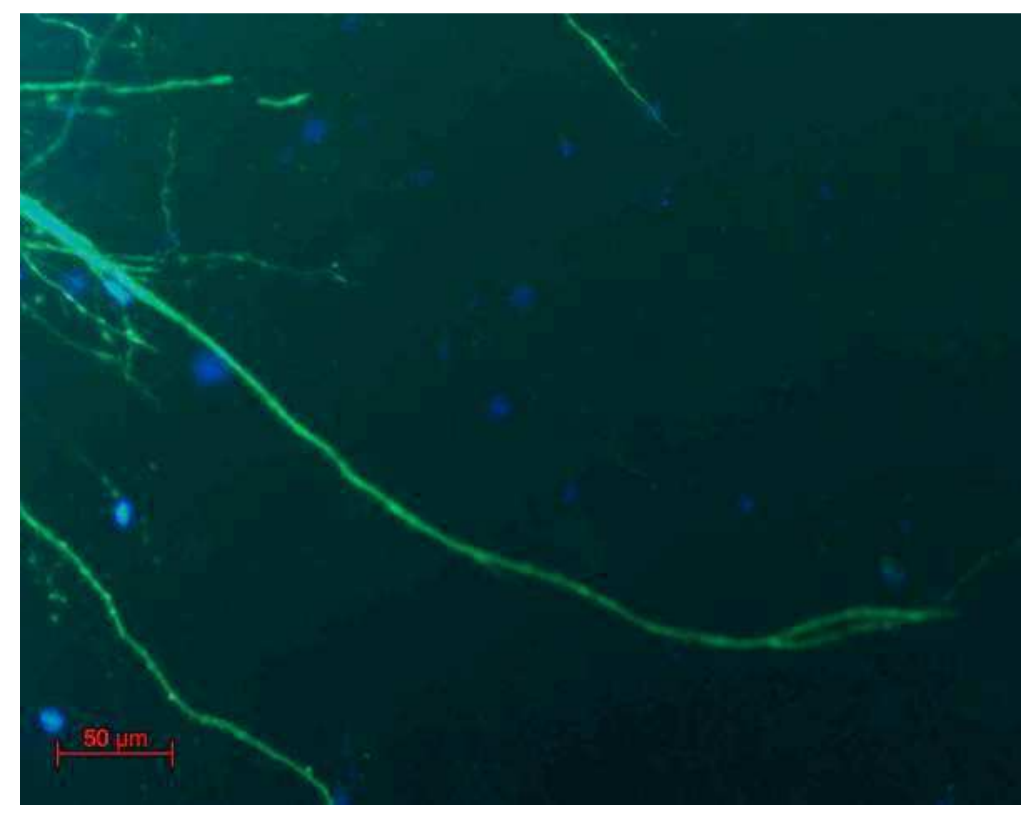

Abb. 5: Aufnahme in 20-facher Vergrößerung nach direkter Erb-InhibitorBehandlung. Dargestellt sind die am Axon liegenden Schwann-Zellen, deren Kerne mit DAPI (blau) angefärbt wurden. Es handelt sich um ein Explantat aus der behandelten Gruppe.

Die Betrachtung eines Schnittes unter dem Fluoreszenzmikroskop reichte aus, den Unterschied zwischen einem Ganglion aus der Kontrollgruppe und einem solchen aus der mit Erb behandelten Gruppe wahrzunehmen.

Zum Teil gestaltete es sich als problematisch, den letzten am Axon befindlichen Kern und das Ende des Axons auf einem Foto abzubilden, da die Abstände auch in der nur 20-fachen Vergrößerung häufig zu groß waren; daher wurden auch die Axone, an denen kein Kern mehr zu erkennen war, in einer eigenen Wertung berücksichtigt. Hier ergibt sich ein Mittelwert von 99,65 $\mu \mathrm{m}$ für die Kontrollgruppe und 345,14 $\mu \mathrm{m}$ für die mit Erb behandelte Gruppe. Entspricht die Länge der Axone ohne Kern aus der Kontrollgruppe $100 \%$, ergibt sich ein Wert von 346,2\%. 


\section{Ergebnisse}

Abbildung 5 zeigt, wie groß der Abstand zwischen dem letzten Schwann-Zellkern und dem Ende des Axons, an welchem er liegt, beträgt. Die absolute Länge lag hier bei $420 \mu \mathrm{m}$, bzw. 417,6 $\mu \mathrm{m}$, bezogen auf nur dieses Bild. Es kommen zwei Werte zustande, da wie erwähnt jeweils die Abstände vom letzten Kern bis zu jedem Ende einer Verzweigung des Axons genommen wurden; an dieser Stelle zwei Endäste und somit zwei Messungen, von einem Kern ausgehend.

Betrachtet man dieses Explantat in seiner Gesamtheit, ergibt sich ein durchschnittlicher Wert des Abstandes letzter Kern-Axonende bei der mit Erb behandelten Gruppe von 243,5 $\mu \mathrm{m}$.

Im Vergleich dazu lag der Wert des Abstandes in der Kontrollgruppe, also der nur mit NGF behandelten Explantate, im Mittel bei 85,24 $\mu \mathrm{m}$.

Setzt man den Mittelwert des Abstandes in der Kontrollgruppe gleich $100 \%$, ergibt sich für die mit Erb behandelte Gruppe ein Wert von 285\%, gemessen an der Kontrollgruppe.

Betrachtet man die Darstellung eines Ausschnittes eines mit Erb behandelten Explantates in größerem Umfang, erkennt man, dass im Vergleich zu Abbildungen aus der Kontrollgruppe die Axone nicht weit auswachsen, sondern häufig sehr dicht am Ganglion liegen. Der Unterschied die Kerne der Schwann-Zellen betreffend ist noch prägnanter; die DAPI-positiven Zellen liegen im mit Erb behandelten Explantat sämtlich im Ganglion oder im nächsten Umfeld; in der Kontrollgruppe erkennt man deutlich die weit in der Peripherie liegenden Kerne, die zum Teil bis zum Ende des Axons, an dem sie entlang gewandert sind, liegen. 


\section{Ergebnisse}

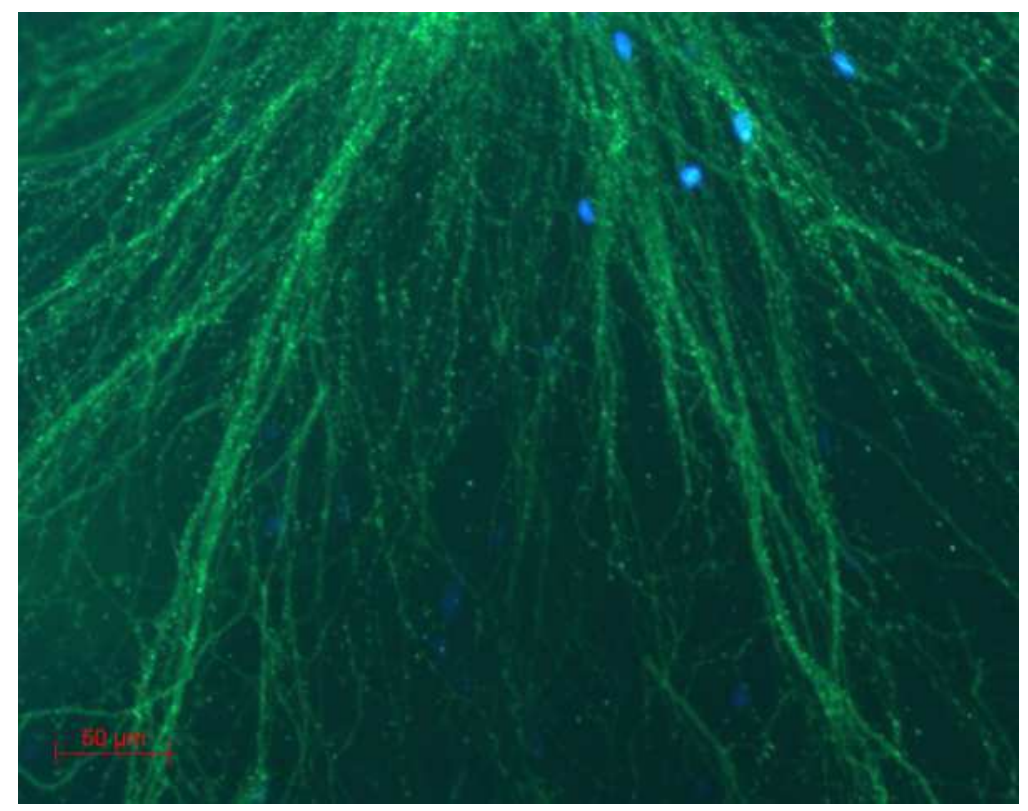

Abb. 6: Foto eines direkt nach Explantation mit Erb-Inhibitor behandelten Ganglions in 20-facher Vergrößerung

Abbildung 6 veranschaulicht, wie wenige Kerne sich außerhalb des Ganglions befinden, nachdem mit dem Erb-Inhibitor behandelt wurde. Ein großer Anteil der Axone, die sich hier vor allem in der linken Bildhälfte befinden, liegt frei von Kernen; obwohl die Enden der Axone häufig außerhalb des hier fotografierten Ausschnittes liegen, sind auch dann keine angefärbten Kerne zu erkennen. In diesem Fall liegen die Kerne weiter zentral, demnach näher am Ganglion und sind mit einer 20-fachen Vergrößerung nicht mehr zu erfassen. Abgesehen davon liegen vereinzelt Kerne in der rechten Bildhälfte an Axonen; zum Teil kann einem solchen Kern sein Axon nicht mehr zugeordnet werden. Bei einem Bild wie in Abbildung 3 wurde aus diesem Grund eine große Anzahl an Messungen vorgenommen, da einem Kern viele Axone bzw. viele Endverzweigungen eines Axons zugeordnet werden.

Für dieses Foto ergab sich ein Mittelwert des Abstandes zwischen letztem Kern und Axonende von $270,56 \mu \mathrm{m}$. 


\section{Sofortige Erb-Inhibitor-Behandlung}

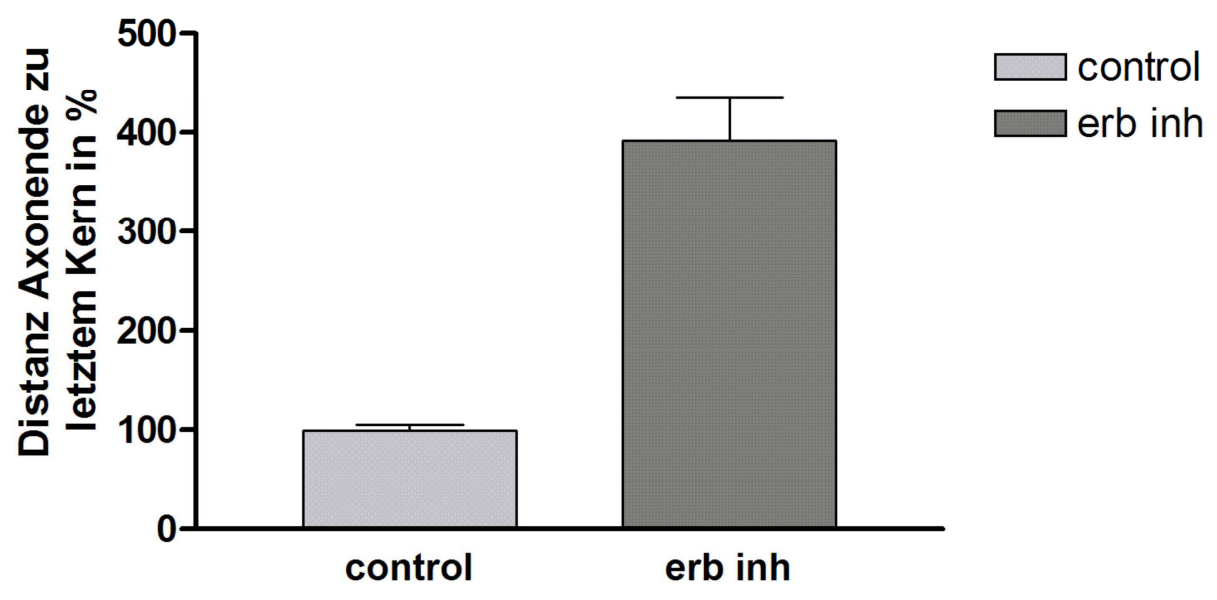

Grafik 1: Repräsentatives Ergebnis des Abstandes des letzten Kerns zum Axonende in der Kontrollgruppe und der mit Erb-Inhibitor behandelten Gruppe nach unmittelbarer Erb-Inhibitor-Behandlung

Im Mittel betrug der Abstand des letzten Kerns zum Axonende in der Kontrolle

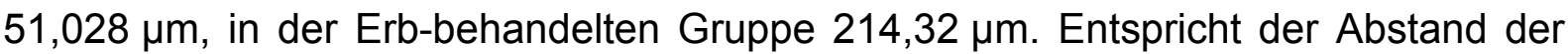
Kontrollgruppe $100 \%$, so liegt er bei der Erb-behandelten Gruppe bei $420 \%$.

\subsubsection{Verzögerte Erb-Inhibitor-Behandlung}

In diesem Experiment wurde der Erb-Inhibitor nicht direkt zwei Stunden nach Explantat in die Schalen gegeben, sondern erst einige Tage später. Es sollte demonstriert werden, dass auch schon wandernde Zellen gestoppt werden können.

Die Kontrollgruppe wurde ebenso wie die Kontrollgruppe des vorherigen Experimentes behandelt: zwei Stunden nach Explantat wurde mit SCG-Medium und NGF behandelt. Nach vier bzw. fünf Tagen wurde der Versuch hier nicht gestoppt, sondern es wurde ein Mediumwechsel vorgenommen, indem bei der Kontrollgruppe wieder SCG-Medium und NGF gegeben wurde, in denselben Konzentrationen wie zu Beginn des Versuchs. Der Unterschied zum Experiment vorher (Erb-InhibitorBehandlung unmittelbar nach Explantat), bezogen auf die Durchführung des Versuchs, liegt bei der Kontrolle darin, dass sie insgesamt über einen längeren 


\section{Ergebnisse}

Zeitraum lief als in dem Experiment mit der direkten Behandlung. Nach dem Mediumwechsel lief der Versuch noch weitere fünf bis sechs Tage weiter, wurde für 24 Stunden mit PFA fixiert, in PBS gelagert und im Anschluss daran geschnitten und gegen TH und DAPI gefärbt.

Es zeigten sich Unterschiede zwischen der Kontrollgruppe und der Gruppe der mit Erb-Inhibitor-behandelten Ganglien. Es konnten sehr ähnliche Ergebnisse festgestellt werden, verglichen mit der Versuchsreihe, in der der Erb-Inhibitor unmittelbar nach Explantat gegeben wurde.

Ebenso wie im vorherigen Experiment wurde eine große Anzahl an Axonen auf den Bildern abgebildet, an denen kein Kern zu beobachten war. In diesen Fällen wurde eine kleine Vergrößerung gewählt, um nach Möglichkeit den letzten am Axon entlang gewanderten Kern mit abzubilden, was mehrmals aufgrund des zu großen Abstands nicht möglich war und dazu führte, dass all diejenigen Axone, an denen kein Kern zu erkennen war, nicht mit in die Wertung der Messungen vom letzten Kern bis zum Axonende eingingen, sondern gesondert berücksichtigt wurden.

Diese Feststellung konnte in diesem Experiment nur auf den Bildern der Explantate gemacht werden, bei denen es sich um mit Erb-Inhibitor behandelte Ganglien handelte, in der Kontrollgruppe gab es kein Axon, an dem kein Kern mit abgebildet war. Für die mit Erb behandelte Gruppe ergab sich ein Mittelwert von 297,22 $\mu \mathrm{m}$ für die Axone, an denen kein Kern mit abgebildet war.

Das Migrationsverhalten der Kontrolle sowie dasjenige der behandelten Ganglien zeigte am Live Cell Imager das gleiche Ergebnis (Heermann et al. 2011). Mit diesem Versuch konnte gezeigt werden, dass Schwann-Zellen, die sich bereits seit Tagen im Prozess der Migration befanden, jegliche Bewegung stoppten, sobald der Inhibitor hinzu gegeben wurde.

Die Messungen ergaben auch in diesem Experiment signifikante Differenzen; während im Mittel der Abstand des letzten Kerns zum Axonende in der Kontrollgruppe $49,66 \mu \mathrm{m}$ betrug, berechnete er sich bei den mit Erb-Inhibitor behandelten Ganglien auf 173,81 $\mu \mathrm{m}$. Entspricht der Abstand der Kontrollgruppe $100 \%$, ergibt sich ein Wert von 350\% für die mit Erb-Inhibitor behandelte Gruppe. 


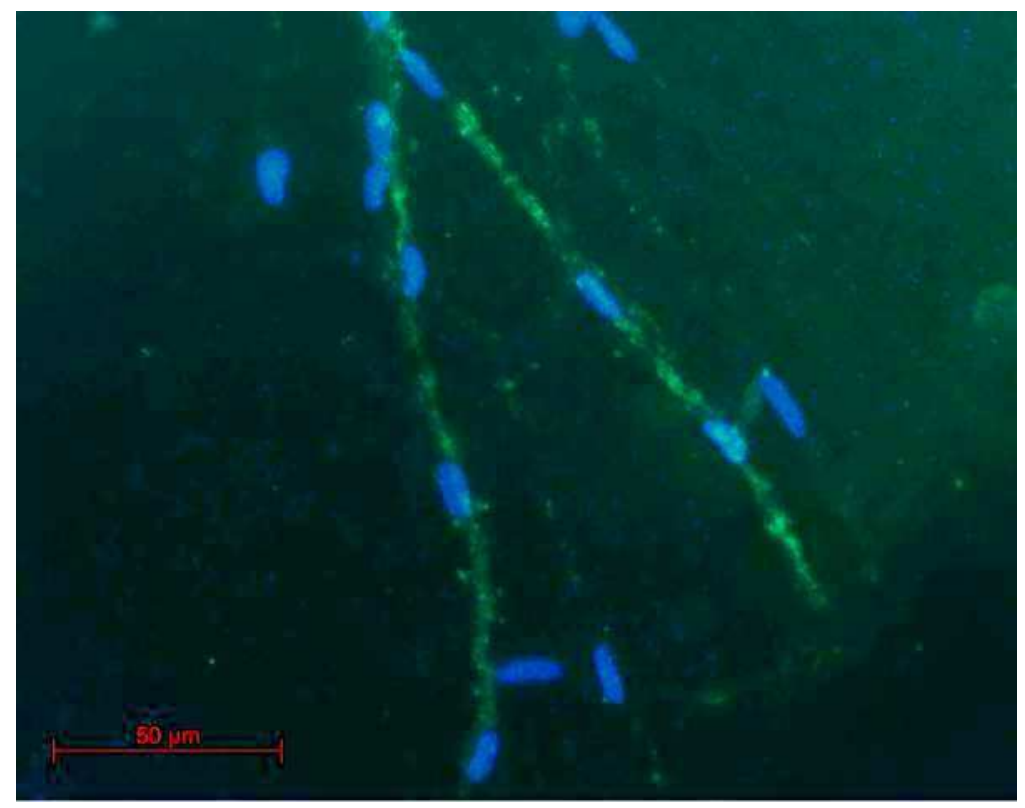

Abb. 7: Abbildung der Kerne der Schwann-Zellen und der Axone in 40-facher Vergrößerung eines Explantates aus der Kontrollgruppe. Das Experiment lief zehn Tage mit Mediumwechsel (erneut SCG und NGF) am fünften Tag

Abbildung 7 zeigt einen Ausschnitt eines Ganglions, welches aus der Kontrollgruppe stammt. Man erkennt deutlich die Schwann-Zellen, die dem Axon direkt anliegen oder darauf liegen, je nachdem, wie das Axon angeschnitten wurde. Ferner liegen die DAPI-positiven Zellen sehr nahe am Ende des Axons. In diesem Fall lag der kürzeste Abstand des letzten Kerns zum Axonende bei $35 \mu \mathrm{m}$. Für die gesamte Schale belief sich der durchschnittliche Wert auf 40,84 $\mu \mathrm{m}$. Im Vergleich dazu war der Abstand bei einem aus der mit Erb-Inhibitor behandelten Gruppe 52,6 $\mu \mathrm{m}$ (Abb. 8) und 514,6 $\mu \mathrm{m}$ (Abb. 9). 


\section{Ergebnisse}

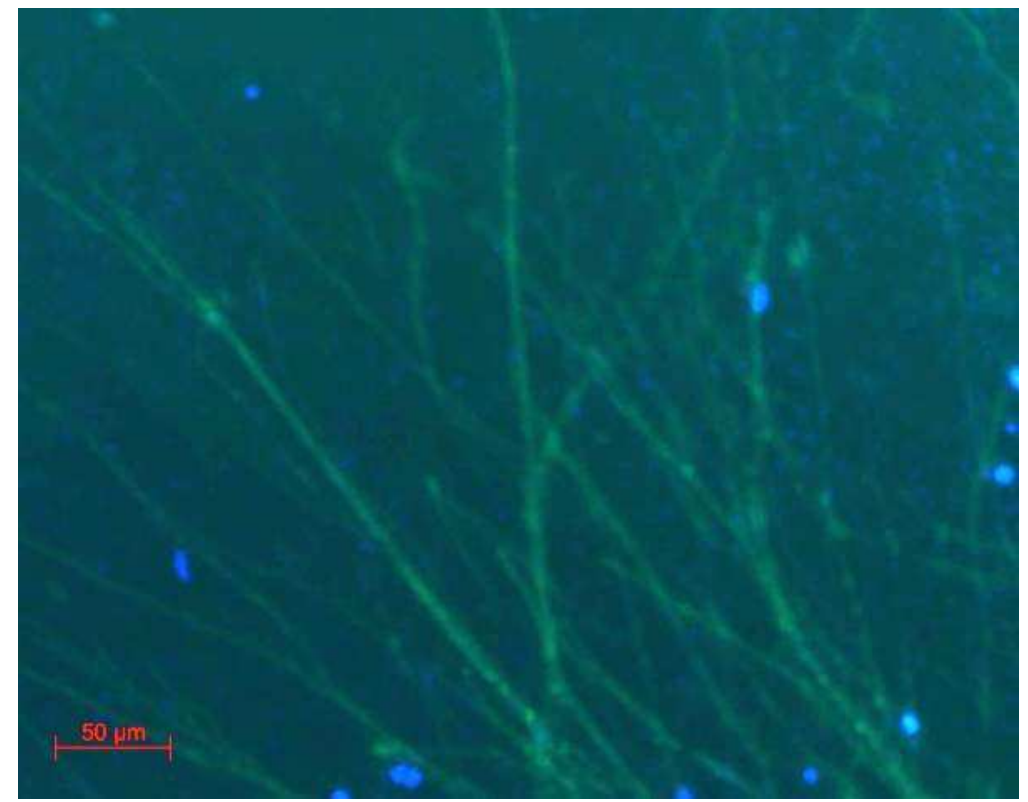

Abb. 8: Ausschnitt eines Ganglions, das einige Tage nach Explantation mit dem ErbInhibitor behandelt wurde. Das Foto wurde in 20-facher Vergrößerung aufgenommen

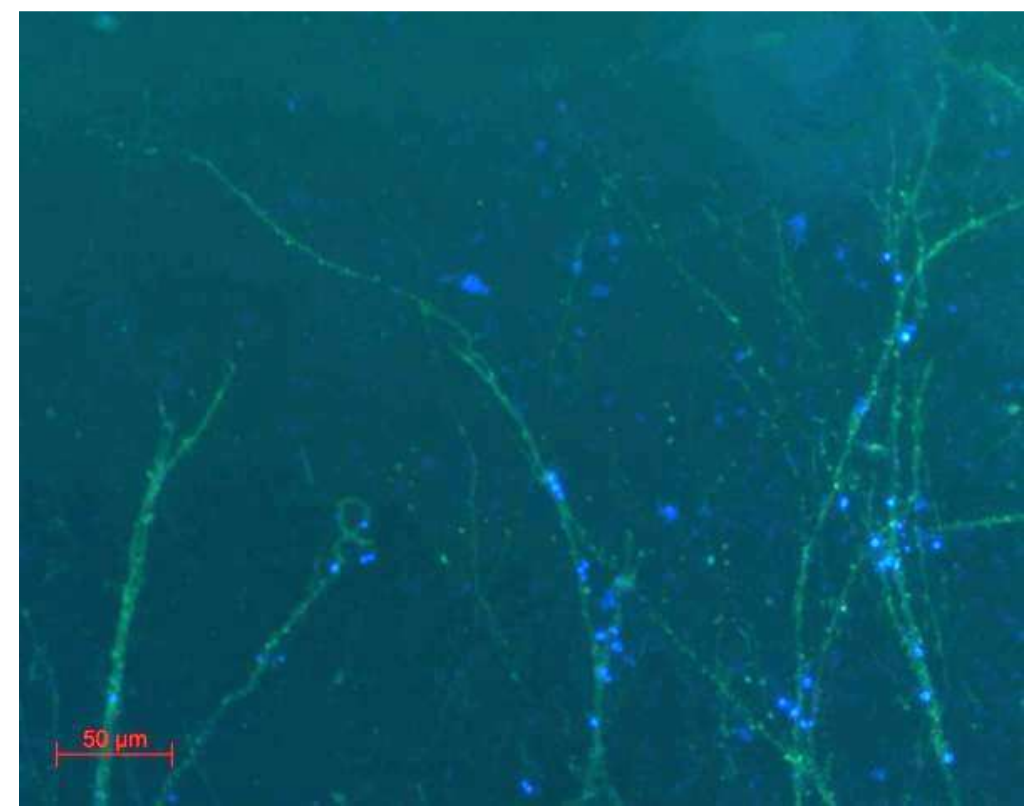

Abb. 9: Aufnahme eines nach einigen Tagen mit Erb-Inhibitor behandelten Ganglions in 20-facher Vergrößerung

In der mit Erb-Inhibitor behandelten Gruppe beläuft sich der Durchschnittswert auf 203,7 $\mu \mathrm{m}$, was eine Differenz in Hinblick auf die Kontrolle von 145,516 $\mu$ m ergibt. Bei 


\section{Ergebnisse}

diesem Explantat entsteht somit eine Verlängerung der Strecke letzter KernAxonende um den Faktor 2,5 im Vergleich zur Kontrollgruppe.

Hier konnten insgesamt weniger Messungen vorgenommen werden, da es aufgrund der weiten Abstände nicht immer möglich war, sowohl den letzten Kern als auch das Ende des entsprechenden Axons auf einem Foto abzubilden. Aufgrund dieser Tatsache wurden auch die Axone gemessen, an denen kein Kern mehr in dem Bereich, der fotografiert wurde, zu sehen war. Dieses Konzept wurde bei jedem Bild, das mit in die Auswertung kam, angewandt, sei es bei einem Bild aus der Kontrollgruppe oder bei einem der behandelten Gruppe. Es war selten in der Kontrollgruppe erforderlich, allein liegende Axone zu messen, da fast immer der letzte Kern nahe am Axonende lag; Axone ohne DAPI-positiven Kern im selben Bildausschnitt waren die Ausnahme, wurden aber gleichwohl berücksichtigt. Bei den mit Erb-Inhibitor behandelten Ganglien entstand eine große Zahl an Bildern, auf denen freiliegende Axone, d.h. Axone ohne daran anliegenden Kern, zu sehen waren. Die Werte der Länge dieser Axone machen einen großen Betrag an Daten in der Auswertung aus. So erhält man für den Ausschnitt in Abbildung 8 einen Mittelwert für die Länge der Axone ohne Kern von 374,1 $\mu \mathrm{m}$, der sich in diesem Falle aus zwei gemessenen Werten ergibt. In Abbildung 9 waren es drei Maße, die mit in die Wertung eingingen und einen Mittelwert von 201,53 $\mu \mathrm{m}$ ergaben für Axone ohne anliegenden Kern. Bei einem Explantat tauchten ausschließlich bei der mit ErbInhibitor behandelten Gruppe Axone in den fotografierten Bereichen auf, die keinen Kern aufweisen konnten. Folglich ergibt sich für dieses Explantat ein Mittelwert für die Länge freiliegender Axone nur in der behandelten Gruppe von 294,34 $\mu \mathrm{m}$.

Betrachtet man ausschließlich das Experiment mit der verzögerten Erb-InhibitorBehandlung, ist in keinem Explantat der Kontrolle ein Axon ohne Kern in die Wertung eingegangen, wohingegen in der Gruppe der Erb-Inhibitor behandelten Ganglien in jedem einzelnen Explantat Werte gemessen wurden, wodurch sich ein durchschnittlicher Wert von 297,2 $\mu$ m Länge ergibt.

Es ergibt sich für die NGF-Kontrollgruppe ein Mittelwert von 40,66 $\mu \mathrm{m}$ und von $200 \mu \mathrm{m}$ für die mit Erb-Inhibitor behandelte Gruppe. In dem gesamten Experiment ist somit eine Verlängerung der Strecke letzter Kern-Axonende um den Faktor 4,9 zu verzeichnen. 


\section{Ergebnisse}

Für das Experiment insgesamt ergibt sich ein Durchschnittswert für den Abstand des letzten Kerns zum Axonende in der Kontrollgruppe von 49,66 $\mu \mathrm{m}$ und in der mit ErbInhibitor behandelten Gruppe von 173,81 $\mu \mathrm{m}$, was eine Verlängerung des Abstandes um den Faktor 3,5 entspricht.

Die Abstände im Experiment der unmittelbar nach Explantat behandelten Ganglien belaufen sich im Vergleich dazu auf ebenfalls 51,028 $\mu \mathrm{m}$ in der Kontrollgruppe und $214,32 \mu \mathrm{m}$ in der behandelten Gruppe. Die Verlängerung des Abstandes vom Axon zum letzten Kern ist hier im Vergleich zur Kontrollgruppe um den Faktor 4,2 größer.

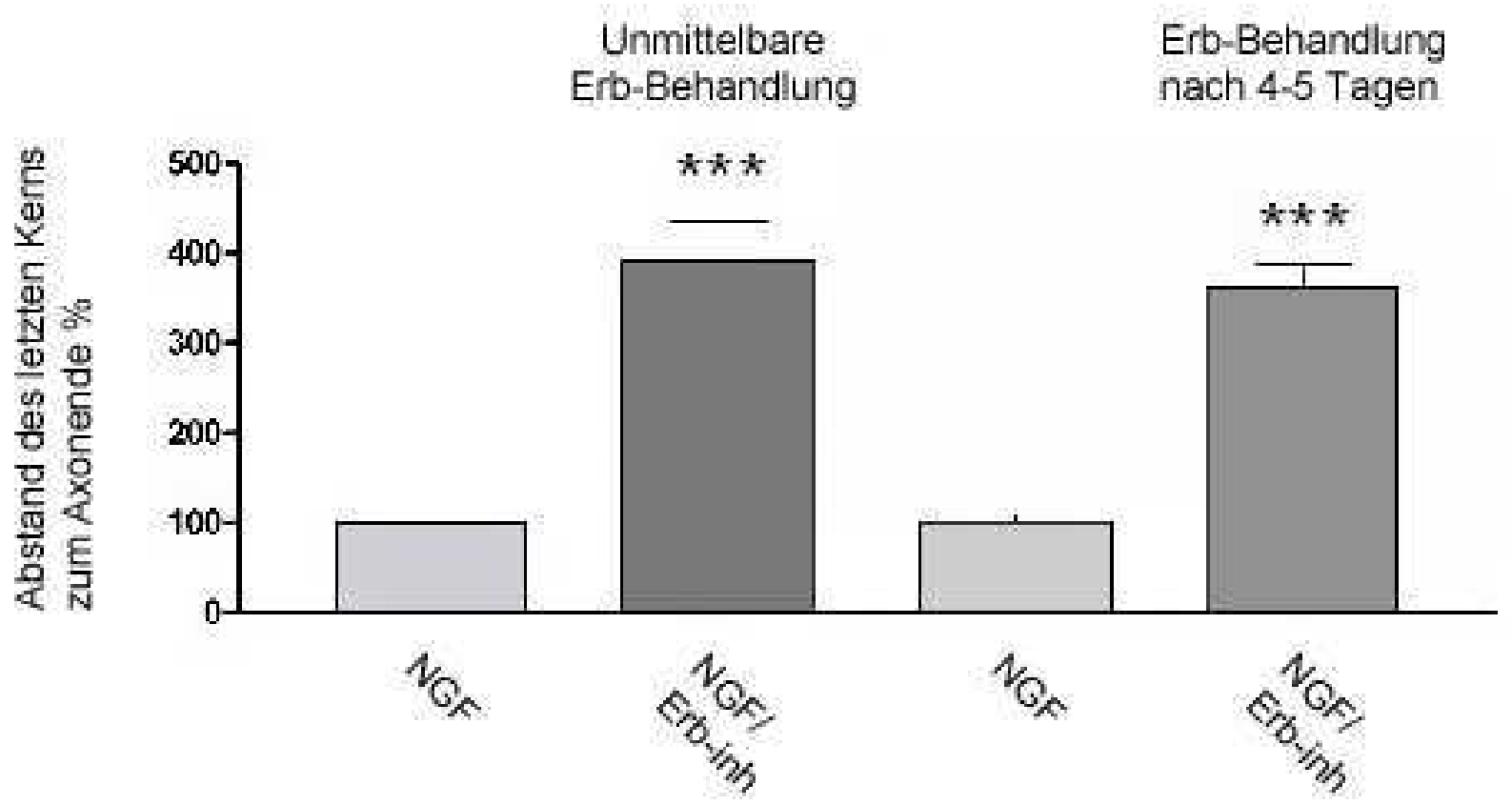

Abb. 10: Direkter Vergleich des Abstandes des letzten Kernes zum Axonende bei unmittelbarer und verzögerter Erb-Inhibitor-Behandlung 


\subsection{Schwann-Zell-Proliferation}

In den vorliegenden Experimenten konnte gezeigt werden, dass Schwann-Zellen entlang der Axone migrieren, in erster Linie in Abhängigkeit vom NeuregulinSignalweg. Um zu differenzieren, ob alleinige Migration oder auch Proliferation eine Rolle bei der Umhüllung der Schwann-Zellen um das Axon spielt, wurde der Proliferationsmarker BrdU eingesetzt, der alle sich gerade in Teilung befindenden Zellen anfärbt, in diesem Falle in Rot.

Es wurde genauso vorgegangen wie im dritten Experiment, in dem der Erb-Inhibitor erst nach vier bis fünf Tagen gegeben wurde; am Tag der Fixierung wurden alle Ganglien vorher für sechs Stunden mit dem Proliferationsmarker BrdU behandelt; gleichzeitig erfolgte dabei ein Mediumwechsel. Dabei wurden die Explantate mit BrdU behandelt. Einen Ausschnitt eines der mit BrdU behandelten Explantate zeigt Abbildung 11.

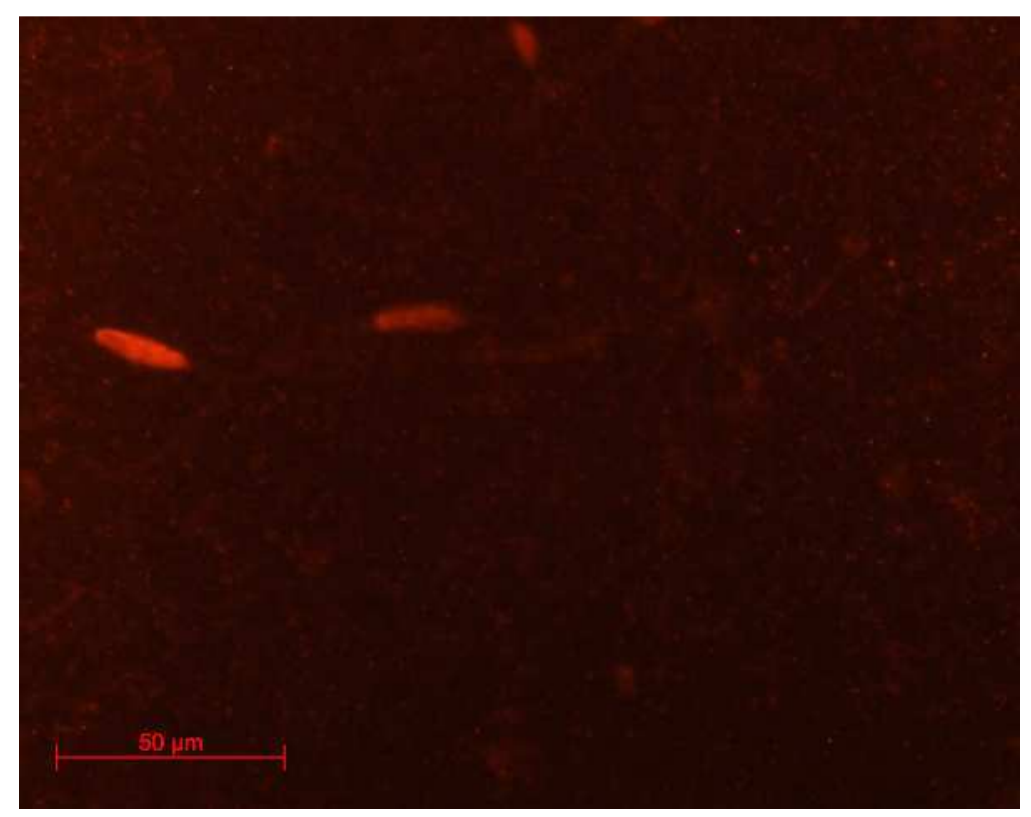

Abb. 11: Gezeigt ist eine Aufnahme eines Ganglions der Kontrollgruppe (nur NGF) eines Explantates der 2. Versuchsreihe (Erb-Inhibitor nach einigen Tagen); die BrdUgefärbten Kerne (rot) entsprechen den sich gerade in Teilung befindenden Zellen 


\section{Ergebnisse}

Um das Verhältnis von Zellen, die sich gerade in Teilung befanden, und solchen, die sich nicht in diesem Zustand befanden, beurteilen zu können, wurde im Blaukanal des Fluoreszenzmikroskops eine Aufnahme des identischen Bildausschnitts gemacht, um darstellen zu können, wie viele DAPI-positive Kerne sich in diesem Bereich befanden (Abb.12).

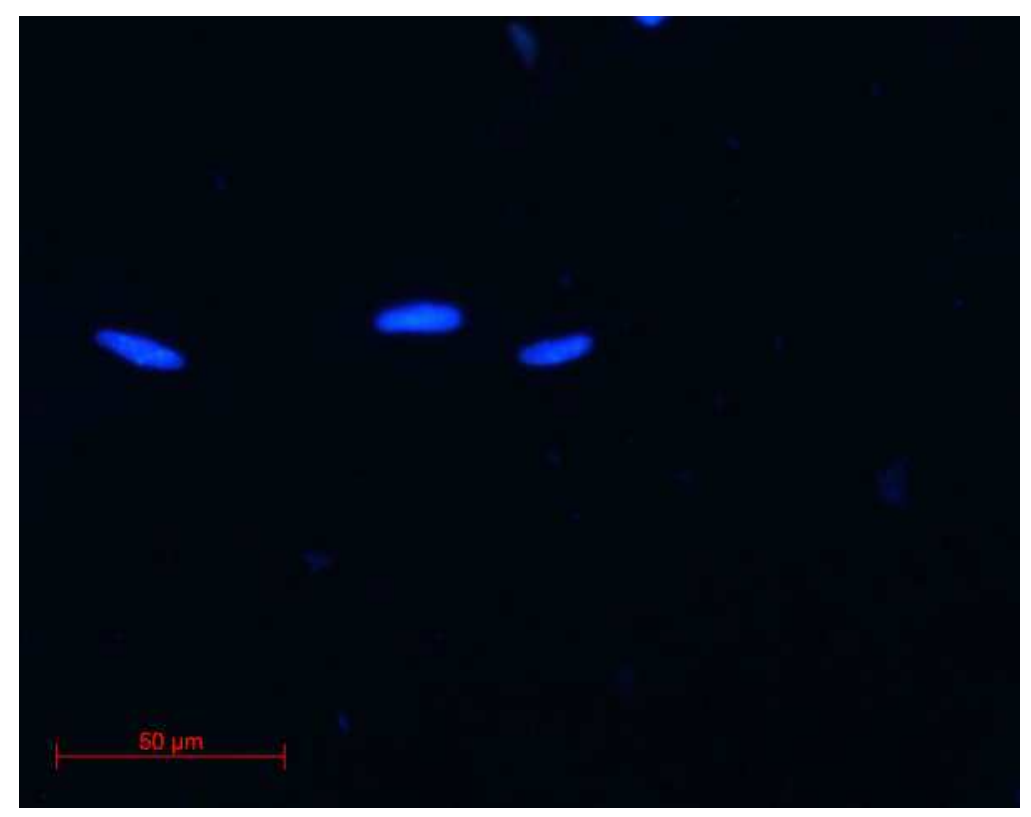

Abb. 12: Dargestellt sind die DAPI-positiven Zellen desselben Bildausschnitts wie in Abb. 11

Für die Auswertung und die Beurteilung des Verhältnisses DAPI-positive zu BrdUpositiven Kernen erwies es sich als unmissverständlicher, die Zählung der Kerne anhand der Einkanal-Bilder zu vorzunehmen, d.h. die Übereinanderlagerung der Bilder wurde zur Zählung der Kerne nicht vorgenommen, sondern die Kerne wurden im Rot-bzw. Blaukanal jeweils einzeln gezählt und im Nachhinein ins Verhältnis gesetzt.

Wie aber eine Aufnahme eines überlagerten Bildes aussieht, ist in Abbildung 13 dargestellt. 


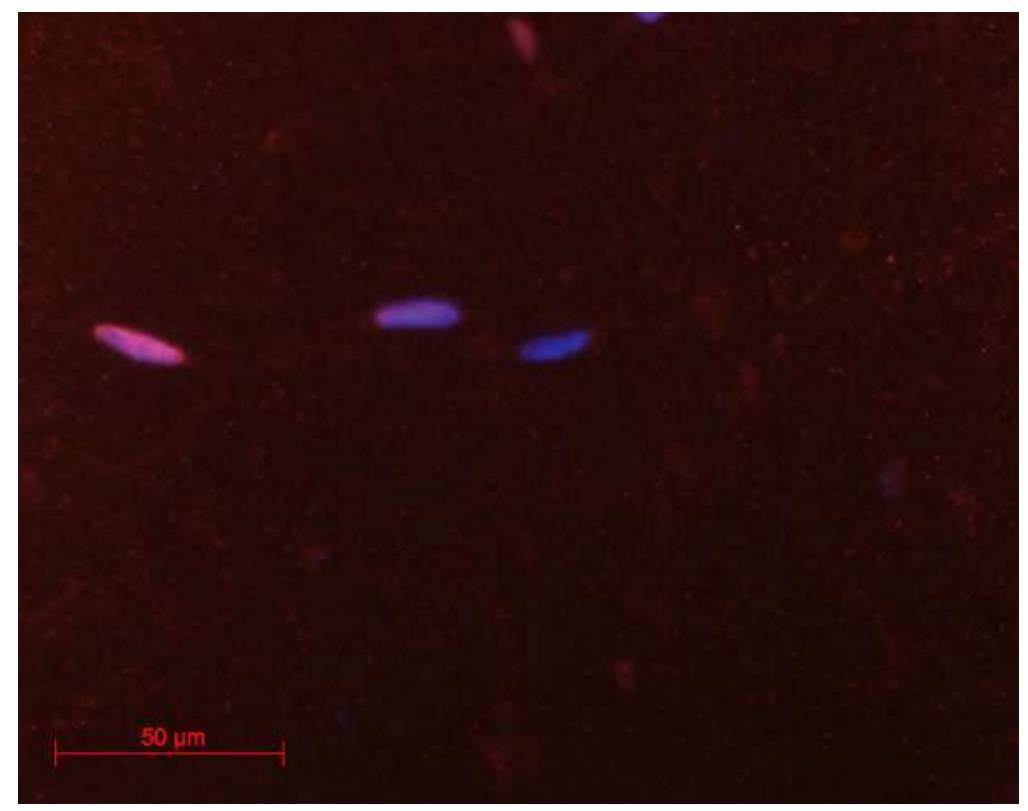

Abb. 13: Überlagerung des Rot- und des Blaukanals; die violett erscheinenden Kerne entsprechen den sowohl DAPI- als auch BrdU-positiven Kernen

In diesem Explantat lag das Verhältnis DAPI zu BrdU in der Kontrollgruppe bei 22:7, was bedeutet, dass 3,26 Mal mehr DAPI-positive Kerne vorlagen als BrdU-positive Kerne

In der mit Erb-Inhibitor behandelten Gruppe entstand eine Relation von 68:6, was eine Vervielfachung der DAPI-Kerne um den Faktor 11,4 im Vergleich zu den BrdUKernen ausdrückt.

Die Abbildungen 14 bis 16 zeigen Ausschnitte von mit Erb behandelten Ganglien, die aus demselben Explantat stammen wie die der unbehandelten Ganglien der Abbildungen 11 bis 13 . 


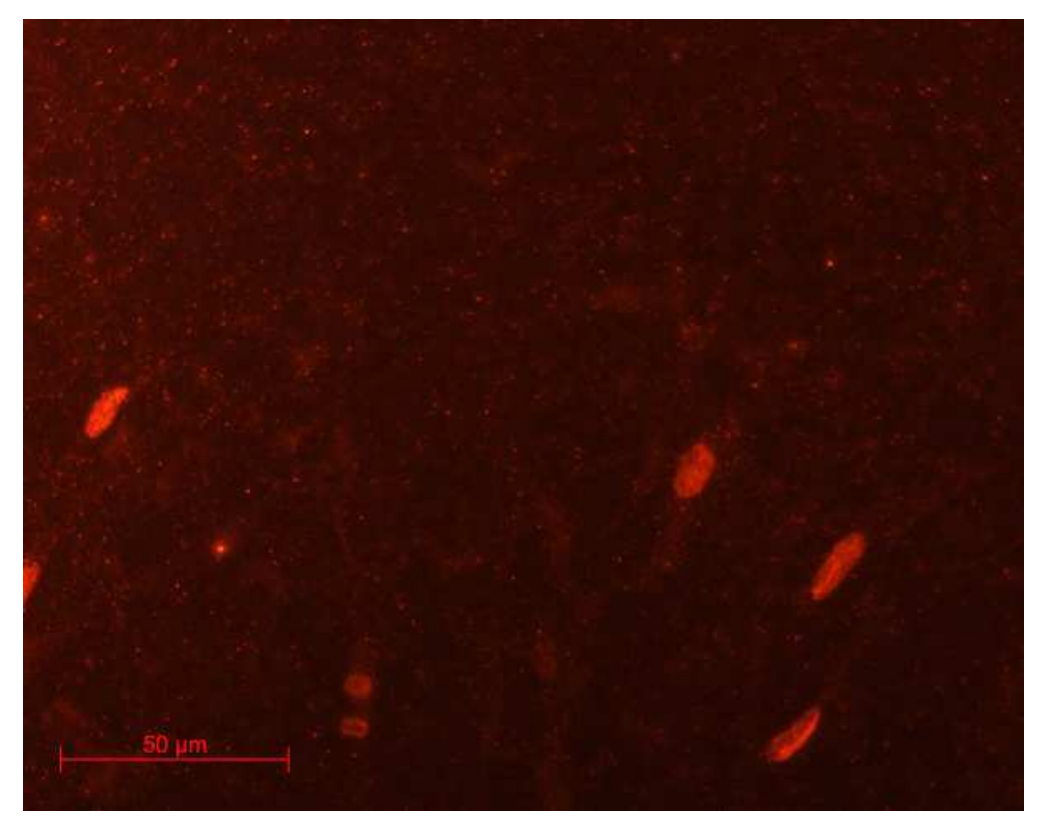

Abb. 14: BrdU-Färbung eines Ganglions, das nach einigen Tagen mit Erb-Inhibitor behandelt wurde

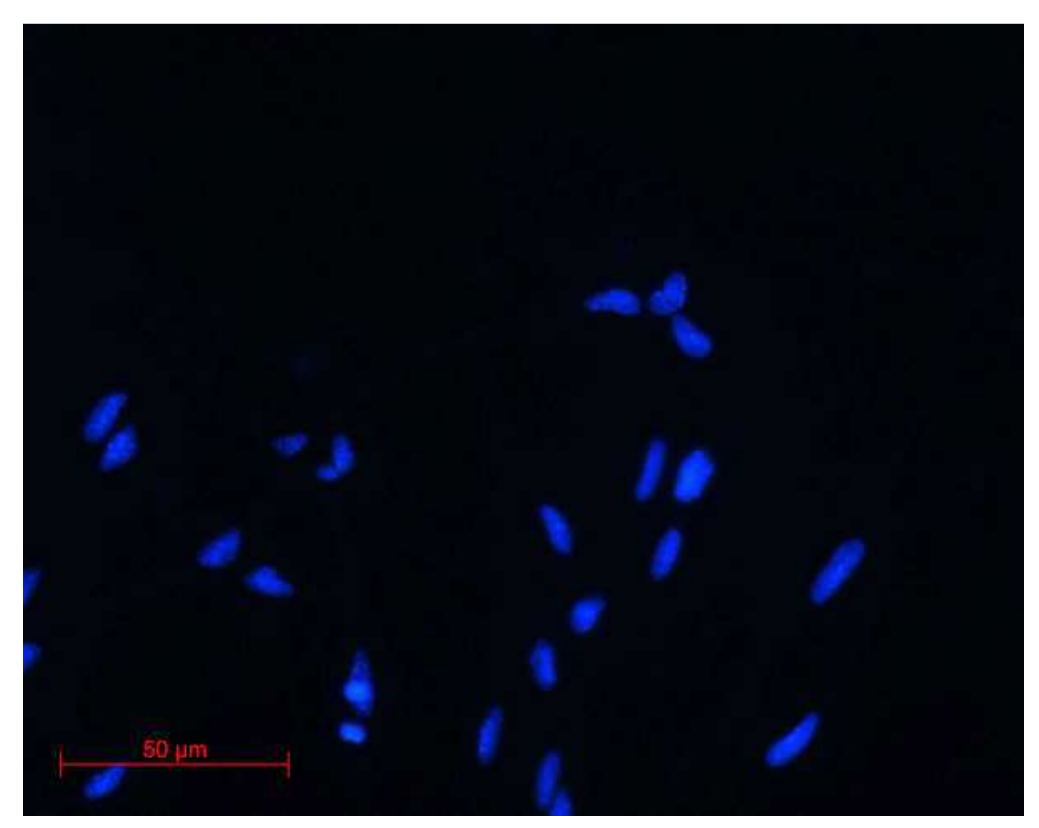

Abb. 15: DAPI-Färbung eines Ganglions, das nach einigen Tagen mit Erb-Inhibitor behandelt wurde; es handelt sich um denselben Bildausschnitt wie in Abb. 14 


\section{Ergebnisse}

Um auch hier den direkten Vergleich darzustellen, wurden die beiden Abbildungen 14 und 15 übereinander gelagert; die violett erscheinenden Kerne stellen wiederum die Kerne dar, die sowohl DAPI-als auch BrdU-positiv gefärbt waren.

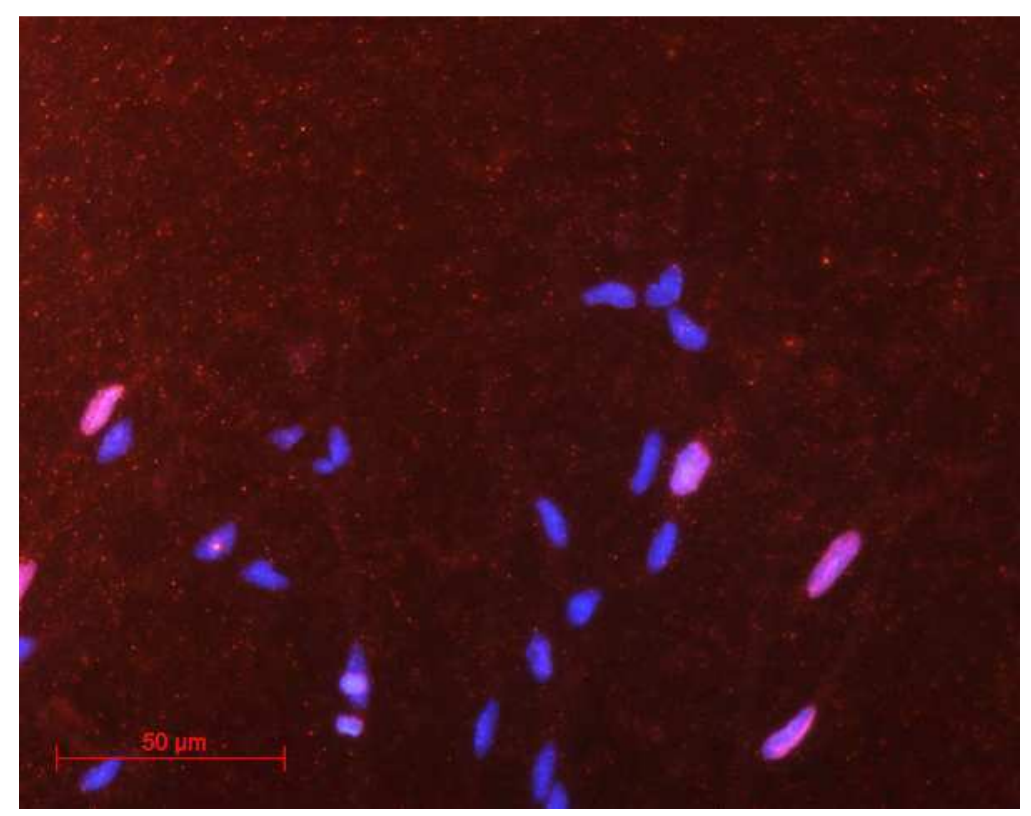

Abb. 16: Überlagerung der Abb. 14 und Abb. 15 zur Darstellung des direkten Verhältnisses zwischen DAPI-positiven (blau) und BrdU-positiven (rot) Kernen

In der Kontrollgruppe betrug der Quotient DAPI/ BrdU im Mittel 105\%, in der mit ErbInhibitor behandelten Gruppe 375\%. Eine Darstellung des Verhältnisses von DAPIpositiven Kernen zu BrdU-positiven Kernen ist schematisch in der Grafik 2 abgebildet. 


\section{Experimente}

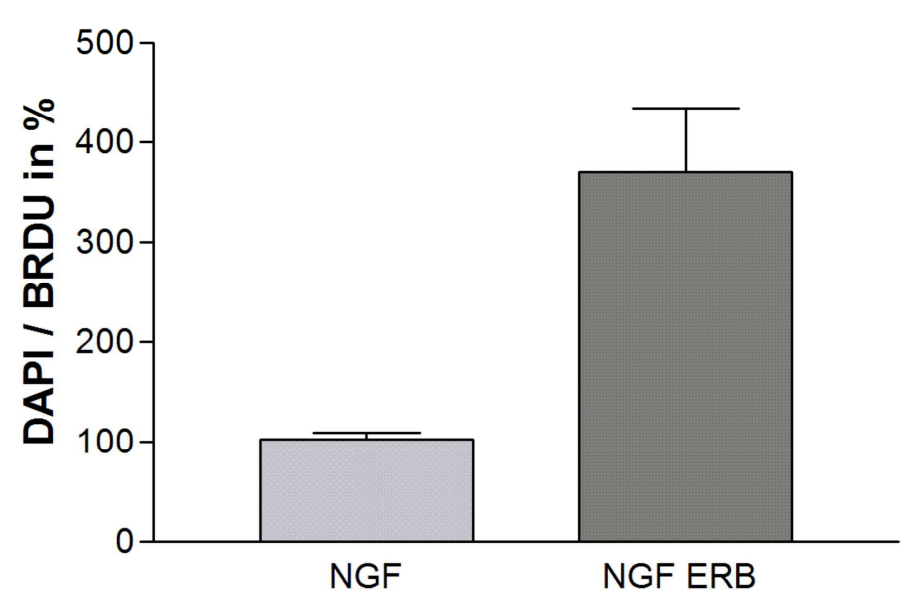

Grafik 2: Vergleich des Verhältnisses DAPI/ BrdU in \% in Kontrollgruppe und mit Erb-Inhibitor behandelter Gruppe; N entspricht den Schalen

Es konnten sowohl bei den Versuchen mit reiner Erb-Inhibitor-Behandlung als auch denjenigen, bei denen zusätzlich BrdU eingesetzt wurde, prägnante Unterschiede festgestellt werden. Nach der Behandlung mit dem Inhibitor wurde ein deutlich reduzierter Anteil an proliferierenden Zellen verzeichnet. Die Tatsache, dass die Schwann-Zellen auch nach verzögerter Verabreichung des Inhibitors die Migration einstellten, zeigte auf der anderen Seite, dass die beobachteten Effekte nicht ausschließlich über die Proliferation erklärt werden konnten. 


\section{Diskussion}

Es ist bisher in der Forschung viel Aufwand betrieben worden, die Migration und Proliferation der Schwann-Zellen entlang von Axonen zu untersuchen. In der Literatur findet man eine große Anzahl von Forschungsarbeiten, die sich mit der Ermittlung der für die Migration von Schwann-Zellen verantwortlichen Signalwege beschäftigt. Die Bedeutsamkeit dieses Themas wird veranschaulicht, indem man sich die mit einer gestörten Funktion der Myelinisierung von Axonen einhergehenden Krankheitsbilder wie z.B. der Multiplen Sklerose, einer mit Entmarkungsherden im ZNS einhergehenden Erkrankung, oder des Guillain-Barré-Syndroms, das das PNS betrifft, vor Augen führt.

Bislang ist nicht abschließend geklärt, welcher Signalweg der ausschlaggebende bei der Entwicklung sowie der Migration von Schwann-Zellen ist. Es sind bereits einige Faktoren und Signalwege bekannt, jedoch ist noch unklar, wie viel Bedeutung jedem dieser Faktoren beigemessen werden kann und ob bzw. in welchem Ausmaß diese Faktoren auf Interaktionen angewiesen sind.

In der vorliegenden Arbeit sind wichtige Ergebnisse bezüglich der für die Migration und Proliferation von embryonalen Schwann-Zellen ausschlaggebenden Signalwege ermittelt worden, die einen Beitrag für weitere Forschung an der Entwicklung von Schwann-Zellen ermöglichen.

Sie identifiziert den durch ErbB-Rezeptoren vermittelten Signalweg als einen bedeutenden Regulator der Schwann-Zell-Migration und -Proliferation im sympathischen Nervensystem. Insgesamt ist bisher wenig über die Regulation der Migration von Schwann-Zell-Vorläuferzellen entlang von Axonen bekannt. Eine Forschungsarbeit von Chen et al. (2003) beschäftigte sich mit nicht-myelinisierenden Schwann-Zellen, die postnatal einen negativ-dominanten ErbB-Rezeptor exprimierten und konnten dabei feststellen, dass diese Maus-Mutanten eine progressive periphere Neuropathie aufwiesen, die gekennzeichnet war durch eine erhebliche Schwann-Zell-Proliferation und gleichzeitige Apoptose. Es soll im Folgenden anhand der Ergebnisse diskutiert werden, welche Faktoren für die 


\section{Diskussion}

Migration bzw. die Proliferation verantwortlich sind und in welchem Zusammenhang sie zueinander stehen.

\subsection{Die Migration von Schwann-Zellen}

GDNF ist ein Wachstumsfaktor, der Einfluss auf die Migration von Schwann-Zellen nimmt. Er wurde ursprünglich anhand von seinen starken trophischen Effekten auf dopaminerge Neurone des Mittelhirns isoliert (Lin LF et al 1993, Lin LF et al. 1994).

Zur Transduktion des GDNF Signals nach intrazellulär kann der GDNF-GFRa1Komplex entweder an die Rezeptortyrosinkinase Ret oder die Isoform des "neuronal cell adhaesion molecule" (NCAM) binden (Euteneuer 2008). Es konnte gezeigt werden, dass GDNF die Schwann-Zell-Migration via NCAM stimuliert; dieser Vorgang ist allerdings unabhängig vom Ret-Signalweg (Paratcha et al. 2003).

Zu demselben Ergebnis kam eine andere Studie, die besagt, dass GDNF auch RETunabhängig über GFRa1 seine Wirkung entfalten kann (Sariola und Saarma 2003). Im Hinblick auf NCAM sind ähnliche Studien bekannt, die zeigen, dass NCAM als ein bedeutendes Zelladhäsions-Molekül im Nervensystem Einfluss auf eine Reihe sich entwickelnder Prozesse hat, darin eingeschlossen die Zell-Migration, das Auswachsen der Axone sowie die synaptische Plastizität (Crossin und Krushel 2000, Rønn et al. 2000, Schachner 1997), was sowohl auf dessen adhäsive Qualitäten als auch auf dessen Eigenschaft als Signalmolekül zurückgeführt wird (Maness et al. 1996). Weitere Untersuchungen ergaben ebenfalls den unmittelbaren Verdacht, dass NCAM eine entscheidende Rolle bei der Migration von Schwann-Zellen zukommt, dargestellt an Explantaten peripherer Nerven (Thomaidou et al. 2001). Andere Forschungsarbeiten hingegen kamen zu dem Ergebnis, dass der RET-Signalweg einer der ausschlaggebenden Wege für die Aktivierung verschiedener intrazellulärer Signalkaskaden ist, welche das Überleben der Zelle, die Differenzierung, Proliferation, Migration, Chemotaxis und das Aussprossen der Axone reguliert (Sariola und Saarma 2003). Einen Anhaltspunkt für die These, dass GDNF von Schwann-Zellen produziert wird, gibt die Beobachtung von mRNA-Exprimierung für GDNF in Schwann-Zellen. Weiterhin wird vermutet, dass Schwann-Zellen eine GDNF-Quelle für periphere Nerven darstellen (Springer et al. 1994). Gewebekultur- 


\section{Diskussion}

Studien haben gezeigt, dass vier Wirkstoffe, NGF (Wood et al. 1990), Insulin-likegrowth-factor (Russell et al. 2000), Progesteron (Koenig et al. 1995) und BDNF (Chan et al. 2001) in vitro die Kapazität zur Aufrechterhaltung oder Zunahme der Myelinisierung von kleinen Axonen besitzen. Bei diesen Auslegungen handelt es sich letztendlich jedoch um Hypothesen, denen entgegengesetzt werden kann, dass Schwann-Zellen einen GDNF-Korezeptor aufweisen, der als GFR- $\alpha 1$ identifiziert wurde (Nosrat et al. 1997; Trupp et al. 1997) und in diesem Zusammenhang eine direkte Interaktion zwischen GDNF und Schwann-Zellen annehmen lässt. In Bezug auf Schwann-Zellen und ihre Verbindung zu verschiedenen Signalmolekülen und wegen muss in diesem Zusammenhang erwähnt werden, dass ein Komplex zwischen $\mathrm{p} 140^{\text {NCAM }}$ und ${ }^{125}$ I-GDNF in Schwann-Zellen sowie in embryonalen hippokampalen und kortikalen Neuronen identifiziert werden konnte, welcher eine hohe Menge an NCAM und GFRa1 exprimiert, jedoch eine nicht nachweisbare Menge an RET (Paratcha et al. 2003).

In der vorliegenden Arbeit wurde sich an der Annahme und den vorliegenden Daten, RET, und folglich GDNF, seien nicht die ausschlaggebenden Signalkaskaden bei der Schwann-Zell-Migration, orientiert.

GDNF spielt eine wesentliche, begünstigende Rolle bei der Entwicklung von Schwann-Zell-Migration in Nerven-Explantaten des N. ischiadicus (Paratcha et al. 2003). Die Signalkaskade, die über GDNF in Bewegung gesetzt wird, gebraucht allerdings unter anderem auch Src-Kinasen, welche das Wachstum der Neuriten und das neuronale Überleben unterstützen (Airaksinen und Saarma 2002). Es sind allerdings ebenfalls Daten vorhanden, die darauf hinweisen, dass die Bindung von Neuregulin1 TypIII an ErbB3/4-Rezeptoren mit nachgeschalteter Src-KinaseStimulation einen erheblichen Einfluss auf die Migration von Schwann-Zellen hat. Im Vorfeld und während der vorliegenden Arbeit wurde die Rolle von GDNF im SCGExplantat-System erforscht. Um den GDNF-Signalweg zu hemmen, wurde im Rahmen der vorliegenden Arbeit der Inhibitor PP2 eingesetzt. PP2 blockiert sowohl den RET-als auch den Src-Kinase-Weg (Carlomagno et al. 2003), demnach den bekannten und den alternativen GDNF-Signalweg. Die Applikation erfolgte jeweils zwei Stunden nach Explantation bei der einen Hälfte der Explantate und wurde gleichzeitig mit dem SCG-Medium und NGF gegeben. Die andere Hälfte wurde als 


\section{Diskussion}

Kontrollgruppe nur mit SCG-Medium und NGF behandelt. Das Hinzufügen von PP2 führte dazu, dass nur sehr vereinzelt Schwann-Zellen an den distalen Abschnitten der Axone nachzuweisen waren und vermutlich auch indirekt dazu, dass Axone mit nur geringer Länge im Vergleich zur Kontrollgruppe gebildet wurden. Unter diesen Gegebenheiten wurde dementsprechend keine Migration der Schwann-Zellen entlang der Axone beobachtet. Gehemmte und noch latent vorhandene SchwannZell-Migration wurden der inkompletten Blockade durch den Inhibitor und dessen Halbwertszeit zugeschrieben.

Bisher blieb ungeklärt, welcher Faktor in welchem Ausmaß an der Migration beteiligt ist und ob diese Faktoren unabhängig voneinander reagieren oder miteinander in Interaktion treten.

\subsubsection{GDNF-Mutanten}

Infolgedessen stellte sich nun die Frage, welcher Faktor bzw. welcher Signalweg ausschlaggebend für die eingeschränkte Migration war. Anhand dieses Versuches war darüber noch keine eindeutige Aussage zu machen, da PP2 sowohl den SrcKinase-Weg als auch den RET-Weg hemmt. Um Belege zu liefern, dass PP2 spezifisch GDNF hemmt, wurden im Rahmen meiner Arbeit GDNF-KnockoutMutanten für das Migrations-Experiment eingesetzt, und in diesem Zuge kam GDNF aufgrund seiner bevorzugten Aktivierung des RET-Weges ins Spiel. Auf diese Weise ergab sich also die Aussicht auf Differenzierung zwischen den beiden Signalwegen und damit, welcher von diesen in erster Linie für die Migration der Schwann-Zellen verantwortlich sei. Entgegen der Erwartung konnte kein Unterschied zwischen der Schwann-Zell-Migration in den Explantaten der GDNF-Mutanten und derjenigen in der Kontrollgruppe festgestellt werden. 


\section{Diskussion}

\subsection{Erb-Inhibitor}

Zunächst konnte im Zusammenhang mit der vorliegenden Arbeit gezeigt werden, dass die getrennte Anwendung von sowohl dem ErbB2/4-Inhibitor als auch von PP2 die Schwann-Zell-Migration nachhaltig beeinträchtigt. Diese Beobachtung spricht also dafür, dass der ErbB-Rezeptor und die Src-Kinase mit großer Wahrscheinlichkeit Komponenten desselben Signalwegs sind, wobei die Wirkung der Src-Kinase derjenigen des ErbB-Rezeptors nachgeschaltet ist. Die Affinität der verschiedenen ErbB-Rezeptoren zum Neuregulin unterscheidet sich allerdings; nur ErbB3, jedoch nicht ErbB2, bindet Neuregulin1 mit hoher Affinität. Der hoch-affine Rezeptor ErbB3 ist allerdings inaktiv; ErbB2 ist derjenige Rezeptor, der zu der Aktivität der nachgeschalteten Tyrosinkinase, die essentiell für den Transduktionsweg ist, beiträgt (Yarden und Sliwkowski 2001). Aufgrund der erwähnten Ergebnisse scheint eine andere Signalkaskade als die des GDNFSignalings, die in Schwann-Zell-Signalwegen aktiv ist, betroffen zu sein. In diesem Kontext war der Neuregulin-Signalweg über die Familie der Src-Kinasen Erfolg versprechend. Um diese Hypothese zu untermauern, wurde in der vorliegenden Arbeit ein anderer Inhibitor herangezogen. Es wurde der EGFR/ErbB2/3-Inhibitor zu den SCG-Explantaten gegeben, und ähnliche Ergebnisse wie in den Experimenten mit dem PP2-Inhibitor konnten beobachtet werden.

Zur Quantifizierung der Ergebnisse wurden hier Kryoschnitte angefertigt, gegen TH und DAPI gefärbt und Fotos am Fluoreszenzmikroskop angefertigt, um dann an jedem Axon die Distanz vom letzten Kern zum Axonende zu messen. Dabei wurde ein signifikanter Unterschied zwischen der Kontrollgruppe und der mit Inhibitor behandelten Gruppe festgestellt. Dies war ebenso der Fall, als der Inhibitor erst einige Tage nach Explantation hinzugefügt wurde, also an einem Zeitpunkt, an dem sich die Schwann-Zellen schon im Prozess der Migration befanden und mit dem Augenblick der Inhibitorgabe die Migration einstellten. In beiden Versuchsreihen deutete alles darauf hin, dass Neuregulin, welches normalerweise über den ErbRezeptor aktiviert wird, ein bedeutender Regulator der Schwann-Zell-Migration ist. Der Stellenwert des Neuregulins wurde durch den zweiten Versuch, in dem der ErbInhibitor erst einige Tage nach Explantation gegeben wurde und die Ganglien bis zu 


\section{Diskussion}

diesem Zeitpunkt unter gleichen Bedingungen gewachsen waren, besonders deutlich.

Bei Lyons et al. (2005) wurden ErbB3-Mutanten eingesetzt, und der erste untersuchte Phänotyp der ErbB3-Mutanten zeigte ein Ausbleiben der Migration von Schwann-Zellen vom PLLg (posterior lateral line ganglion); auch zu späteren Zeitpunkten, an denen die gesamte Länge des aussprossenden Nerven unter normalen Umständen von Gliazellen umgeben wäre (Gilmour et al. 2002), hatte augenscheinlich keine Migration stattgefunden.

Die in der vorliegenden Arbeit hervorgebrachten Daten zeigen zwar ähnliche Ergebnisse, nichtsdestoweniger konnte unter Anwendung des Erb-Inhibitors Migration beobachtet werden, die jedoch stark eingeschränkt im Vergleich zur Kontrollgruppe, aber dennoch vorhanden war. Andererseits konnte bei Lyons et al.(2005) aber gezeigt werden, dass dieses Phänomen der nicht stattgefundenen Migration nicht Ausdruck einer erfolgten Apoptose der ErbB3-Mutanten sein konnte, da kein Unterschied der Anzahl an apoptotischen Zellkörpern zwischen den ErbB3Mutanten und dem Wildtyp ermittelt werden konnte (Lyons et al. 2005). Die Forschungsarbeiten von Chen et al. (2003), bei denen ErbB-Mutanten untersucht wurden, zeigen indessen, dass sensorische C-Faser-Neurone in adulten Tieren durch Apoptose zugrunde gehen, was durch eine reduzierte Expression von GDNF vermutet wurde. In dem Zusammenhang wurde ein Apoptosemarker und ein Antikörper gegen ErbB4 eingesetzt, und das Ergebnis zeigte, dass alle zugrunde gehenden Zellen Schwann-Zellen waren (Chen et al. 2003).

Anhand der in der vorliegenden Arbeit durchgeführten Versuche konnte gezeigt werden, dass der Neuregulin-Signalweg sowohl am Anfang der embryonalen Entwicklung als auch dann, wenn die Entwicklung schon begonnen hat, ein bedeutender Weg in der Regulation der Migration und der Proliferation embryonaler Schwann-Zellen ist.

Zusammenfassend lässt sich aus diesen Versuchen schließen, dass der RetSignalweg nicht für die Migration der Schwann-Zellen verantwortlich gemacht werden kann, sondern vielmehr der Src-Kinase-Weg, der über Neuregulin aktiviert wird. Diese Studie widerlegt folglich die Annahme, GDNF sei der einzige oder zumindest der maßgebliche Faktor für die Schwann-Zell-Migration. GDNF hat keinen Einfluss auf die im Rahmen dieser Arbeit ermittelten Daten. 


\section{Diskussion}

Auf der anderen Seite haben wiederum andere, unabhängige Forschungsarbeiten gezeigt, dass GDNF die Migration von Schwann-Zellen fördert (Paratcha et al. 2003), was in Anbetracht der Tatsache, dass GDNF in ungewöhnlich hohen Mengen in sich entwickelnden und regenerierenden peripheren Nerven exprimiert wird, nahe liegt (Paratcha et al. 2003). In jener Forschungsarbeit wurde ebenso auf die Proliferation eingegangen, die allerdings unter den genannten Gesichtspunkten unverändert blieb. In der vorliegenden Arbeit soll auf den Seiten 59-62 näher auf den Aspekt der Proliferation eingegangen werden. Ebenso wurde in einer weiteren Studie der chemische Inhibitor PP2 in Verbindung mit neutralisierenden Antikörpern gegen entweder GDNF oder gegen einen Rezeptor, der wichtig für den "non-canonical“ GDNF-Signalweg über NCAM war, eingesetzt (Sariola und Saarma 2003). In diesem Zusammenhang konnte ebenfalls unter Beweis gestellt werden, dass GDNF die Schwann-Zell-Migration in diesem System fördert.

Die vorliegende Arbeit stellt nun allerdings zum ersten Mal Daten dar, die durch Untersuchungen an Mäusen gewonnen wurden mit NRG1 als einem Faktor, der die Migration von Schwann-Zellen bestimmt. Die hier ermittelten Daten zeigen, dass der Signalweg des Neuregulins über den ErbB-Rezeptor und die nachfolgende Signalkaskade erheblichen Einfluss auf die Migration und Proliferation der SchwannZellen haben.

\subsection{Neuregulin-Knockouts}

Die ersten in-vivo-Studien mit Mäusen, die gezielte Mutationen im Neuregulin1-Gen oder ErbB2-bzw. ErbB3-Gen aufwiesen, veranschaulichen, dass die Neuregulin1/ErbB-Signalwege für die Entwicklung der Schwann-Zellen absolut notwendig sind (Garratt et al. 2000a). Andere, neuere Daten weisen des Weiteren darauf hin, dass das Neuregulin1-Signaling über ErbB-Rezeptoren eine Rolle spielt bei der Entscheidung, ob ein peripheres Axon myelinisiert oder nicht myelinisiert wird und wie ausgeprägt anschließend die Dicke des Myelins ausfallen wird (Birchmeier und Nave 2008). In Forschungsarbeiten, die sich mit der Frage beschäftigen, welche Faktoren zu welchem Zeitpunkt positiv bzw. negativ auf die Schwann-ZellEntwicklung einwirken, taucht auch dort Neuregulin als wesentlich beteiligter Faktor 


\section{Diskussion}

auf. Dabei konnte sowohl in vivo als auch in vitro gezeigt werden, dass Neuregulin1 neben Endothelin das Überleben und die Differenzierung von Zellen, die der Neuralleiste entspringen und sich zu Schwann-Zell-Vorläuferzellen entwickeln, reguliert (Brennan et al. 2000, Garratt et al. 2000b). Diese beiden Neurotrophine unterscheiden sich allerdings in ihren Merkmalen: $\beta$-Neuregulin ist im Gegensatz zu Endothelin in der Lage, DNA-Synthese in Vorläuferzellen zu induzieren, und die Arbeit von Jessen und Mirsky (2002) lässt vermuten, dass Endothelin als ein negativer Regulator des Übergangs von Vorläuferzellen zu Schwann-Zellen fungiert. Nachdem gezeigt werden konnte, dass NRG1 eine Rolle bezüglich der Mobilität von Schwann-Zellen spielt (Meintanis et al. 2001, Yamauchi et al. 2008), und vor allem, nachdem gezeigt wurde, dass NRG1 die Migration von Schwann-Zellen im Zebrafisch fördert (Lyons et al. 2005), wurden die Daten aus den NRG1-und ErbBMaus-Mutanten dennoch abweichend interpretiert (Lai 2005, Birchmeier und Nave 2008).

Bezüglich der Ergebnisse dieser Arbeit sind weitere Daten, die im Zusammenhang mit der vorliegenden Arbeit stehen, bedeutsam. Da man sich im Rahmen der vorliegenden Arbeit nach dem Einsatz von GDNF-Mutanten, die keine Veränderung bezüglich der Migration aufwiesen, auf den Neuregulin-Signalweg fokussiert hatte, wurden Neuregulin-Knockouts eingesetzt (Heermann et al 2011). Hier konnten bei Untersuchungen von SCGs, die von den NRG1 Typ III -Mutanten-Embryos stammten, das Fehlen von Schwann-Zellen, und zwar hauptsächlich an den distalen Axonenden der NRG1-Typ-III-Mutanten, festgestellt werden. Die Ergebnisse der NRG1-Typ-III-Mutanten können in unmittelbaren Zusammenhang mit den Ergebnissen der vorliegenden Arbeit gebracht werden. Auch hier konnten keine oder nur vereinzelt Schwann-Zellen an den distalen Enden der Axone beobachtet werden, sobald der Erb-Inhibitor, der den Neuregulin1-Signalweg unterbricht, hinzugegeben wurde. Diese Erkenntnis macht die Aussage geltend, dass NRG1 Typ III eine deutliche Auswirkung auf die Migration der Schwann-Zellen entlang sich entwickelnder Axone hat. Demgegenüber führten Lyons et al. (2005) das distale Fehlen von Schwann-Zellen in ihren Versuchen am Zebrafisch darauf zurück, dass die Proliferation der Migration nachgeschaltet ist, demzufolge Migrieren noch möglich war, aber aufgrund der fehlenden Proliferation zu wenig Zellen die distalen Bereiche erreichen konnten. Die vorliegenden Ergebnisse sowie diejenigen von Heermann et 


\section{Diskussion}

al. (2011) sind die ersten, die aus Versuchen mit Mäusen stammen und Neuregulin als den Faktor, der die Migration von Schwann-Zellen fördert, erkennt.

\subsection{Neuregulin ist ein bedeutender Faktor für die Migration und Proliferation von Schwann-Zellen}

Frühere Daten, die von NRG1-Typ-III- (Wolpowitz et al. 2000), ErbB3-(Riethmacher et al. 1997) und ErbB2-Maus-Mutanten (Lin W et al. 2000) erlangt wurden, manifestierten sich in einem Mangel an Schwann-Zellen an den peripheren Nerven. An jenen Stellen, an denen die Rezeptor-Mutanten ein komplettes Fehlen von Schwann-Zellen aufzeigten, wiesen die NRG1 Typ III-Mutanten bei Heermann et al. (2011) einen vollständigen Mangel an Schwann-Zellen im Speziellen an den distalen Bereichen der peripheren Nerven auf. Diese Ergebnisse entsprechen denjenigen, die im Rahmen der vorliegenden Arbeit mit Hilfe der Anwendung des Erb-Inhibitors gemacht wurden. Hier wurde die reduzierte Anzahl von Schwann-Zellen durch verminderte Proliferation und gesteigerte Apoptose von Schwann-Zellen, die sich in Abwesenheit vom NRG1-Signalweg befanden, erklärt. Ebenso ließen Heermann et al. (2011) dieselbe Interpretation als sehr wahrscheinlich erscheinen. Desgleichen gelangte man in anderen Forschungsarbeiten zu der Aussage, dass, da Neuregulin die Proliferation fördert und die Apoptose mindert, dieser Signalweg als ein Schwann-Zell-Mitogen und Überlebensfaktor angesehen werden kann (Brockes et al. 1980; Lemke GE und Brockes 1984; Dong et al. 1995).

\subsubsection{Zytostatikum-Experiment}

Um zu veranschaulichen, dass Schwann-Zellen auch ohne stattfindende Proliferation am Axon entlang migrieren konnten, wurde bei Lyons et al. (2005) bei Versuchen am Zebrafisch Hydroxyurea als Inhibitor der DNA-Synthese und Aphidicolin als Antibiotikum eingesetzt, um auf diese Weise die Proliferation zu hemmen. Die deutliche Reduktion an mitotischen Zellen (zwischen 18 und 28 hours post fertilisation) wurde in einer Phase beobachtet, die sowohl prämigratorische 


\section{Diskussion}

Zeitpunkte mit erfasst als auch einen Zeitraum, der durch die Migration von Schwann-Zellen gekennzeichnet ist. Hier konnte jetzt deutlich festgestellt werden, dass die Migration in der mit Zytostatikum bearbeiteten Gruppe im Vergleich zur Kontrollgruppe nicht beeinträchtigt war, demzufolge das Zytostatikum keine Wirkung auf die Migration von Schwann-Zellen hat.

Die bedeutendste Erkenntnis in Bezug auf die Migration und die Proliferation von Schwann-Zellen liegt demnach in der Arbeit von Lyons et al (2005). darin, dass gezeigt werden konnte, dass Schwann-Zellen auch dann am Axon entlang migrieren können, wenn keine Zellteilung stattfindet. Auf diese Weise war es möglich, eine Aussage darüber zu treffen, ob die Migration und die Proliferation zwei miteinander gekoppelte oder zwei unabhängig voneinander ablaufende Prozesse sind. Aus diesen Beobachtungen konnte geschlossen werden, dass ErbB3 unabhängige, essentielle Funktionen bezüglich der Migration und der Proliferation von SchwannZell-Vorläuferzellen übernimmt (Lyons et al. 2005) und dass Schwann-Zellen, die bereits migriert sind, einer erheblichen Proliferation unterzogen werden, die partiell von der ErbB-Signalkaskade abhängig ist. Diese postmigratorische Proliferation konnte als notwendig für die Myelinisierung der Axone interpretiert werden (Lyons et al. 2005).

Lyons et al. (2005) gingen aufgrund ihrer erhobenen Daten davon aus, dass die Migration zeitlich vor der Proliferation stattfindet, beides in Abhängigkeit vom ErbBSignaling, aber gegenseitig unabhängig voneinander. Die postmigratorische Proliferation wurde in diesem Zusammenhang als notwendiger Prozess für die Fähigkeit zur Myelinisierung angesehen.

Um die beiden Sachverhalte Migration und Proliferation eigenständig zu beurteilen, wurden bei Heermann et al. (2011) die Explantate für vier bis fünf Tage ausschließlich mit Medium und NGF behandelt, um dann die eine Hälfte weiterhin mit Medium und NGF zu behandeln, und die andere Hälfte mit Medium und Zytostatikum. Hier konnte jetzt deutlich festgestellt werden, dass die Migration in der mit Zytostatikum bearbeiteten Gruppe im Vergleich zur Kontrollgruppe nicht beeinträchtigt war, demzufolge das Zytostatikum keine Wirkung auf die Migration von Schwann-Zellen hat. Aufgrund dieser Ergebnisse konnte mit diesem Experiment belegt werden, dass die Migration und die Proliferation von Schwann-Zellen auch bei der Maus zwei voneinander unabhängig verlaufende Prozesse sind. 


\section{Diskussion}

Auch die Ergebnisse, die in der vorliegenden Arbeit gewonnen werden konnten, deuten darauf hin, dass die Proliferation der Schwann-Zellen überwiegend zeitlich nach der Migration stattfindet. Diese Erkenntnis entstammt im Wesentlichen den bereits erwähnten Versuchen, bei denen der Prolifertionsmarker BrdU nach einigen Tagen angewendet wurde, nachdem vorher neben einer Kontrollgruppe eine Gruppe von Explantaten mit ErbB-Inhibitor behandelt worden war. Die vorliegende Arbeit sowie die erhobenen Daten von Lyons et al. (2005) und Heermann et al. (2011) zeigen deutlich, dass Schwann-Zellen auch bei fehlender Zellteilung entlang von Axonen migrieren können. Schlussfolgernd lässt sich sagen, dass ErbB3 unabhängige, grundlegende Funktionen während der Migration und Proliferation von Schwann-Zell-Vorläuferzellen übernimmt (Lyons et al. 2005).

Schließlich gilt gleichwohl die Aussage, dass das Erb-Signaling für beide Vorgänge erforderlich ist, was die Versuchsreihen mit der Gabe des Erb-Inhibitors bezeugen. Somit lässt sich schlussfolgern, dass das Erb-Signaling zwar für beide Prozesse, aber nicht für beide Prozesse zu ein und demselben Zeitpunkt bzw. zur selben zeitlichen Phase der Entwicklung von Schwann-Zellen zuständig ist. Die hier erhobenen Daten stimmen mit der bisher einzigen Studie, die die gleichen Prozesse untersucht hat, überein. Die von Lyons et al. (2005) schon vor dieser Arbeit entstandene Studie über die Abhängigkeit bzw. Unabhängigkeit von Migration und Proliferation in embryonalen Schwann-Zellen bezieht sich wie erwähnt jedoch auf Daten, die aus Experimenten am Zebrafisch stammen, die Ergebnisse von Heermann et al. jedoch aus Versuchen an der Maus, was die in dieser Arbeit erhobenen Daten nochmals untermauert.

\subsection{Proliferation von Schwann-Zellen}

Hinsichtlich der Proliferation von Schwann-Zellen wurden in anderen Forschungsarbeiten Erkenntnisse erlangt, die im Zusammenhang mit dem TGF $\beta$ Rezeptor stehen, der von Schwann-Zellen exprimiert wird oder von den Axonen selbst produziert wird. Bisher wurde Neuregulin1 zumeist als das hauptsächliche Mitogen betrachtet, das von Schwann-Zellen umhüllender Axone ausgeht (Jessen und Mirsky 2004, Jessen und Mirsky 2005). In diesem Zusammenhang ergab sich 


\section{Diskussion}

dann die Hypothese, dass Neuregulin1 und TGF $\beta$ bezüglich der Steigerung der Proliferation von Schwann-Zellen kooperieren (D’Antonio et al. 2006). Diese These wurde in Versuchen bestätigt, wobei das Neuregulin1 von den Axonen und das TGF $\beta$ wie erwähnt von den Schwann-Zellen und/oder den Axonen stammte. Allerdings konnte auch verdeutlicht werden, dass TGF $\beta$ immer in Abhängigkeit vom Kontext agiert, und ebenso wie als Mitogen auch als Inhibitor der Schwann-ZellProliferation fungieren kann, denn in Abwesenheit von Neuregulin1 induzierte TGF $\beta$ die Apoptose (D’Antonio et al. 2006).

Neuregulin1 und TGF $\beta$ beeinflussen sich gegenseitig, was sich dadurch zeigte, dass die Wirkung von TGF $\beta$ verstärkt wurde, wenn Neuregulin1 bereits vorhanden war und einen noch erheblicheren Effekt bei sehr niedrigen Neuregulin1-Mengen aufwies (D'Antonio et al. 2006). Es wurden bei Mäusen TGFß-Knockouts eingesetzt (D'Antonio et al. 2006), und diese Mutanten zeigten eine deutliche Reduktion der Schwann-Zell-Proliferation. Demgegenüber haben weitere Studien darauf hingewiesen, dass in in-vitro-DRG-Neuron/ Schwann-Zell-Kokulturen TGF $\beta$-1 die Schwann-Zell-Proliferation hemmt (Einheber et al. 1995; Guénard et al. 1995a, 1995b).

Ein weiterer interessanter Aspekt, der aus den Daten des Zebrafischs (Lyons et al. 2005) hervorgeht, ist, dass der Neuregulin-Signalweg sowohl die Proliferation als auch die Migration beeinflusst, während allerdings die Hemmung der Proliferation allein nicht in der Lage war, die Migration komplett zu inhibieren. Demnach kamen Lyons et al. zu dem Schluss, dass Neuregulin auf beide Prozesse unabhängig voneinander einwirkt. In dieser Studie (Lyons et al. 2005) wurden Mutanten für alle vier Gene des ErbB-Rezeptors eingesetzt, und die Auswertung der Ergebnisse war charakterisiert durch ein Fehlen der Expression von mbp (myelin basic protein) im PNS, jedoch offensichtlich normaler Expression im ZNS. Mbp ist ein Marker, der in myelinisierenden Gliazellen im PNS und ZNS massiv exprimiert wird. Die Analyse dieser Markergene in den Mutanten zeigte, dass ErbB3 und ErbB2 essentiell für die frühen Phasen der Gliazellentwicklung im PNS sind, was sich in einer stark verminderten Expression von sox10 und krox20 äußerte; dies sind Transkriptionsfaktoren, die die Migration und die Myelinisierung von Schwann-Zellen günstig beeinflussen. In der vorliegenden Arbeit wurde zur Kontrolle der Migration 


\section{Diskussion}

und Proliferation nicht die Expression von Transkriptionsfaktoren ermittelt und bewertet, sondern hier wurden die behandelten Explantate nach einigen Tagen im Medium fixiert und nach stattgefundener Immunofluoreszenzbehandlung direkt unter dem Mikroskop beurteilt bzw. Fotos gemacht, an denen es dann möglich war, den Abstand vom letzten Schwann-Zell-Kern zum Axonende objektiv zu beurteilen.

Anlässlich der Vermutung, dass beide Vorgänge maßgeblich daran beteiligt seien und der damit aufkommenden Fragestellung, in welchem Maße Migration oder Proliferation für die Umhüllung des Axons verantwortlich sei, und ob, wie angenommen, die Proliferation sowohl vor, als auch, und dies in weit größerem Ausmaß, während der Migration ein bedeutender Vorgang sei, wurde unter dieser Fragestellung der Proliferationsmarker BrdU eingesetzt, der alle sich gerade in Teilung befindenden Zellen anfärbt.

Im Anschluss wurde die Kontrollgruppe, also die nur mit Medium und NGF behandelten Explantate, mit der Gruppe der mit ErbB behandelten Gruppe verglichen. Auch hier konnte ein signifikanter Unterschied festgestellt werden, der gekennzeichnet war durch eine deutlich höhere Anzahl an sich teilenden Zellen in der Kontrollgruppe im Vergleich zur mit Erb-Inhibitor behandelten Gruppe, die sehr viel weniger proliferierende Zellen aufweisen konnte. Ebenfalls sagen die Interpretationen von Chen et al. (2003) aus, dass vom Axon stammendes Neuregulin1 die Proliferation von Schwann-Zellen während der embryonalen Entwicklung fördert, sie jedoch ganz im Gegensatz dazu im adulten Tier hemmt. Diese Beobachtung ist sehr ähnlich zu denjenigen, die im Zusammenhang mit Proliferation und Zugrundegehen von denervierten Schwann-Zellen distal einer Nervenverletzung stehen (Scherer und Salzer 1996, Carroll et al. 1997) und Kwon et al. (1997) bestätigten, dass trotz der Aktivierung des Neuregulin1-Signalwegs während nervlicher Degeneration (Carroll et al. 1997, Kwon et al. 1997), diese Signalkaskade die Proliferation von Schwann-Zellen nicht zu beeinträchtigen scheint, wenn eine Nervenverletzung vorliegt (Atanasoski et al. 2006). In der hier vorliegenden Arbeit, in der es um die embryonale Entwicklung von Schwann-Zellen geht, wurde die Migration und die Proliferation von Schwann-Zellen bzw. ihren Vorläufern zum ersten Mal an Mäusen unter der Natur sehr nahe kommenden Bedingungen untersucht. Es konnte zunächst im Vorfeld dieser Arbeit festgestellt werden, dass die Gabe des Inhibitors PP2, der die Src-Kinase hemmt, vor allem die 


\section{Diskussion}

Proliferation hemmt, und die Gabe des Erb-Inhibitors, der die Bindung von Neuregulin1 an den Erb-Rezeptor verhindert, zu einer deutlichen Beeinträchtigung der Migration sowie der Proliferation der embryonalen Schwann-Zellen führte. In diesem Zusammenhang drängte sich daraufhin die Frage auf, ob diese beiden Vorgänge bei der Maus zwei voneinander abhängige oder unabhängige Prozesse sind und damit mit den Ergebnissen am Zebrafisch von Lyons et al. (2005) übereinstimmen. 


\section{Zusammenfassung}

Schwann-Zellen sind Gliazellen des peripheren Nervensystems, die für die Myelinisierung von Nervenaxonen zuständig sind und gleichzeitig eine nutritive Funktion übernehmen.

Während der Entwicklung müssen Schwann-Zellen proliferieren und entlang der auswachsenden Axone wandern.

Die bisherige Literatur nennt viele Faktoren, die die Ausbreitung von Schwann-Zellen begünstigen. Welcher dieser Faktoren die entscheidende Rolle spielt, bleibt unklar.

Die dreidimensionale Explantat-Kultur ist ein geeignetes und aussagekräftiges Mittel, die Schwann-Zell-Migration zu erforschen, indem sie das natürliche Habitat der Schwann-Zellen, das Axon, beinhaltet. Deshalb reflektiert es während der Entwicklung sehr viel besser die in-vivo-Situation als Scratch-Assays oder Emigration-Assays von durchtrennten Nerven-Explantaten. Die Berechtigung zu dieser Aussage wird ferner vervollständigt, wenn der Versuch mit dem Live-CellImaging (Heermann et al. 2011) kombiniert wird.

In der vorliegenden Arbeit wurden Kulturen eingesetzt, um die Schwann-ZellWanderung entlang von Axonen zu untersuchen, die aus dem Ganglion cervicale superius auswachsen. Nach Hemmung des Erb-Signalwegs, über den natürlicherweise Neuregulin 1 wirkt, wurden Schwann-Zell-Wanderung und Schwann-Zell-Proliferation untersucht.

Es kann anhand der Ergebnisse dieser Arbeit eine Aussage darüber gemacht werden, inwiefern Migration und Proliferation von embryonalen Schwann-Zellen bei der Maus miteinander verbunden sind bzw. in welchem Zusammenhang sie zueinander stehen. So konnte gezeigt werden, dass zwar Migration und Proliferation beide in direktem Zusammenhang mit dem Neuregulin-Signalweg stehen, dass jedoch beide Prozesse unabhängig voneinander ablaufen.

Unter Erb-Inhibitor-Einfluss war das nicht von Schwann-Zellen besiedelte Axonende knapp viermal so lang wie in den Kontrollgruppen.

Dabei können nicht nur Schwann-Zellen an der Migration, sondern auch bereits migrierende Schwann-Zellen an der weiteren Wanderung gehindert werden. 
Dementsprechend wurde hier eine ungefähr dreieinhalbmal so lange Strecke vom letzten Schwann-Zell-Kern bis zum Axonende wie in den Kontrollgruppen gemessen. Ebenso zeigte sich, dass in Kontrolltieren etwa die dreifache Zahl an Schwann-Zellen proliferierte im Vergleich zu Erb-Inhibitor-behandelten Kulturen.

Somit kann anhand der Ergebnisse gesagt werden, dass der Neuregulin-ErbSignalweg sowohl die Migration als auch die Proliferation von embryonalen Schwann-Zellen fördert und damit ein wichtiger Regulator der Schwann-ZellMigration und Schwann-Zell-Proliferation in postganglionären sympathischen Nerven ist. 


\section{Abkürzungsverzeichnis}

$\begin{array}{ll}\text { Abb. } & \text { Abbildung } \\ \text { AP2 } & \text { Adaptor complex } \\ \text { Aqua dest. } & \text { Aqua destillata } \\ \text { B } & \text { Beta } \\ \text { BA } & \text { Emissionswellenlänge } \\ \text { BDNF } & \text { Brain- Derived Neurotrophic Factor } \\ \text { BPNST } & \text { Benigner Peripherer Nervenscheidentumor } \\ \text { BrdU } & \text { Bromodeoxyuridin } \\ \text { bzw. } & \text { Beziehungsweise } \\ { }^{\circ} \text { C } & \text { Grad Celsius } \\ \text { CIDP } & \text { Chronisch inflammatorische demyelinisierende Polyneuropathie } \\ \text { cm } & \text { Zentimeter } \\ \text { CM } & \text { konzentriertes Medium } \\ \text { CNTF } & \text { Ciliary Neurotrophic Factor } \\ \text { Cy3 } & \text { Cyanine 3 } \\ \text { DAPI } & \text { 4',6-Diamidin-2-phenylindol } \\ \text { d.h. } & \text { das heißt } \\ \text { DMEM } & \text { Dulbecco's modified Eagle medium } \\ \text { DNA } & \text { Desoxyribonukleinsäure } \\ \text { DPBS } & \text { Dulbecco's Phosphat Buffered Saline } \\ \text { DRG } & \text { Dorsal Root Ganglion } \\ \text { EGF } & \text { Epidermal-Growth-Factor } \\ \text { EGFR } & \text { Epidermal-Growth-Factor-Receptor } \\ \text { ErbB } & \text { Human epidermal-growth-factor } \\ \text { et al. } & \text { et alii } \\ \text { Ex } & \text { Anregungswellenlänge } \\ \text { Expl. } & \text { Explant } \\ \text { FGF } & \text { Fibroblast Growth Factor } \\ & \end{array}$


FITC

Fyn

GBS

GDNF

$\mathrm{H}_{3} \mathrm{BO}_{3}$

$\mathrm{HCl}$

IGF

jpg.

Kat. Nr.

LIF

Mbp

MEM

$\mu \mathrm{g}$

$\mu \mathrm{l}$

$\mathrm{ml}$

$\mu \mathrm{m}$

$\mathrm{mM}$

mRNA

MS

N.

$\mathrm{NaCl}$

$\mathrm{NaHCO}_{3}$

$\mathrm{NaOH}$

NCAM

NDF

NDS

NGF

$\mathrm{nm}$

NMRI

NRG

NT-3

PBS
Fluoresceinisothiocyanat

Proto-oncogene tyrosine-protein kinase

Guillain- Barré- Syndrom

Glial cell line- derived neurotrophic factor

Borsäure

Salzsäure

Insulin- like growth factor

Joint Photographic Experts Group

Katalognummer

Leukemia Inhibitory Factor

myelin basic protein

modified Eagle medium

Mikrogramm

Mikroliter

Milliliter

Mikrometer

Millimolar

messenger Ribonukleinsäure

Multiple Sklerose

Nervus

Natriumchlorid

Natriumhydrogencarbonat

Natriumhydroxid

Neuronal Cell Adhaesion Molecule

Neu-Differentiation-Factor

Normal Donkey Serum

Nerve growth factor

Nanometer

Naval Medical Research Institute

Neuregulin

Neurotrophin- 3

phosphatgepufferte Salzlösung (phosphat buffered saline) 
PDGF Platelet- derived growth factor

PDGF-BB Platelet- derived growth factor, subunit B, homodimer

PFA Paraformaldehyd

$\mathrm{pH} \quad$ pondus Hydrogenii

PLLg Posterior Lateral Line ganglion

PNS Peripheres Nervensystem

PP2-Inhibitor 4-amino-5-(4-chlorophenyl)-7-(t-butyl)

pyrazolo[3,4d]pyramidine

PSN Penicillin/Streptomycin/Neomycin

RET Rezeptor-Tyrosinkinase

$\mathrm{Rr}$.

Rami

RT-PCR Reverse Transkriptase- Polymerase- Kettenreaktion

$\mathrm{S}$ Seite

SCG Ganglion cervicale superius

sox10 SRY-related HMG-box 10

S-Phase Synthesephase

Src-Kinase cellular sarcoma Tyrosinkinase

TGF $\beta \quad$ Transforming Growth Factor beta

TH Tyrosine 3-monooxygenase

$\mathrm{U} / \mathrm{min} \quad$ Umdrehungen pro Minute

w/v Mass-volume percentage

x Mal

z.T. zum Teil

ZNS Zentrales Nervensystem

$\% \quad$ Prozent 


\section{Abbildungsverzeichnis}

Abb. 1: Schematische Darstellung der Schwann-Zell-Entwicklung sowie der Möglichkeit der Rückbildung von myelinisierenden zu nicht-myelinisierenden Schwann-Zellen (Jessen und Mirsky 2005, S. 673)

Abb. 2: Neuregulin-Signaling über den ErbB-Rezeptor 14

Abb. 3: Aufnahme in 40-facher Vergrößerung. Färbung mit S100 (rot), DAPI (blau), und TH (grün) zur Darstellung von Schwann-Zell-Kernen am Axon

Abb. 4: Aufnahme in 20-facher Vergrößerung aus der Kontrollgruppe nach direkter Erb-Inhibitor-Behandlung. Dargestellt sind die am Axon liegenden SchwannZellen, deren Kerne mit DAPI (blau) angefärbt wurden.

Abb. 5: Aufnahme in 20-facher Vergrößerung nach direkter Erb-InhibitorBehandlung. Dargestellt sind die am Axon liegenden Schwann-Zellen, deren Kerne mit DAPI (blau) angefärbt wurden. Es handelt sich um ein Explantat aus der behandelten Gruppe.

Abb. 6: Foto eines direkt nach Explantation mit Erb-Inhibitor behandelten Ganglions in 20-facher Vergrößerung

Abb. 7: Abbildung der Kerne der Schwann-Zellen und der Axone in 40-facher Vergrößerung eines Explantates aus der Kontrollgruppe. Das Experiment lief zehn Tage mit Mediumwechsel (erneut SCG und NGF) am fünften Tag . 39

Abb. 8: Ausschnitt eines Ganglions, das einige Tage nach Explantation mit dem ErbInhibitor behandelt wurde. Das Foto wurde in 20-facher Vergrößerung aufgenommen

Abb. 9: Aufnahme eines nach einigen Tagen mit Erb-Inhibitor behandelten Ganglions in 20-facher Vergrößerung

Abb. 10: Direkter Vergleich des Abstandes des letzten Kernes zum Axonende bei unmittelbarer und verzögerter Erb-Inhibitor-Behandlung...

Abb. 11: Gezeigt ist eine Aufnahme eines Ganglions der Kontrollgruppe (nur NGF) eines Explantates der 2. Versuchsreihe (Erb-Inhibitor nach einigen Tagen); die BrdU-gefärbten Kerne (rot) entsprechen den sich gerade in Teilung befindenden Zellen.

Abb. 12: Dargestellt sind die DAPI-positiven Zellen desselben Bildausschnitts wie in Abb. 11 
Abb. 13: Überlagerung des Rot- und des Blaukanals; die violett erscheinenden Kerne entsprechen den sowohl DAPI- als auch BrdU-positiven Kernen 45

Abb. 14: BrdU-Färbung eines Ganglions, das nach einigen Tagen mit Erb-Inhibitor behandelt wurde 46

Abb. 15: DAPI-Färbung eines Ganglions, das nach einigen Tagen mit Erb-Inhibitor behandelt wurde; es handelt sich um denselben Bildausschnitt wie in Abb. 1446 Abb. 16: Überlagerung der Abb. 14 und Abb. 15 zur Darstellung des direkten Verhältnisses zwischen DAPI-positiven (blau) und BrdU-positiven (rot) Kernen 47 


\section{Literaturverzeichnis}

Airaksinen MS, Saarma M (2002): The GDNF family: signalling, biological functions and therapeutic value. Nat Rev Neurosci; $\underline{3(5)}: 383-94$.

Atanasoski S, Scherer SS, Sirkowski E, Leone D, Garratt AN, Birchmeier C, Suter U (2006): ErbB2 signaling in Schwann cells is mostly dispensable for maintenance of myelinated peripheral nerves and proliferation of adult Schwann cells after injury. J Neurosci; 26(7):2124-31.

Bhattacharyya A, Frank E, Ratner N, Brackenbury R (1991): P0 is an early marker of the Schwann cell lineage in chickens. Neuron; $\underline{7(5)}: 831-44$.

Birchmeier C, Nave KA (2008): Neuregulin-1, a key axonal signal that drives Schwann cell growth and differentiation. Glia; $\underline{56(14)}: 1491-7$.

Brennan A, Dean CH, Zhang AL, Cass DT, Mirsky R, Jessen KR (2000): Endothelins control the timing of Schwann cell generation in vitro and in vivo. Dev Biol; 227(2):545-57.

Britsch S, Li L, Kirchhoff S, Theuring F, Brinkmann V, Birchmeier C, Riethmacher D (1998): The ErbB2 and ErbB3 receptors and their ligand, neuregulin-1, are essential for development of the sympathetic nervous system. Genes Dev; 12(12):1825-36.

Brockes JP, Lemke GE, Balzer DR (1980): Purification and preliminary characterization of a glial growth factor from the bovine pituitary. J Biol Chem; 255(18):8374-7.

Carlomagno F, Vitagliano D, Guida T, Basolo F, Castellone MD, Melillo RM, Fusco A, Santoro M (2003): Efficient inhibition of RET/papillary thyroid carcinoma oncogenic kinases by 4-amino-5-(4-chloro-phenyl)-7-(t-butyl)pyrazolo[3,4-d]pyrimidine (PP2). J Clin Endocrinol Metab; 88(4):1897-902. 


\section{Literaturverzeichnis}

Carroll SL, Miller ML, Frohnert PW, Kim SS, Corbett JA (1997): Expression of neuregulins and their putative receptors, ErbB2 and ErbB3, is induced during Wallerian degeneration. J Neurosci; 17(5):1642-59.

Chan JR, Cosgaya JM, Wu YJ, Shooter EM (2001): Neurotrophins are key mediators of the myelination program in the peripheralnervous system. Proc Natl Acad Sci U S A; $\underline{98(25): 14661-8 . ~}$

Chen S, Rio C, Ji RR, Dikkes P, Coggeshall RE, Woolf CJ, Corfas G (2003): . Disruption of ErbB receptor signaling in adult non-myelinating Schwann cells causes progressive sensory loss. Nat Neurosci; $\underline{6(11)}$ :1186-93.

Corfas G, Velardez MO, Ko CP, Ratner N, Peles E (2004): Mechanisms and roles of axon-Schwann cell interactions. J Neurosci; 24(42):9250-60.

Crossin KL, Krushel LA (2000): Cellular signaling by neural cell adhesion molecules of the immunoglobulin superfamily. Dev Dyn; 218(2):260-79.

D'Antonio M, Droggiti A, Feltri ML, Roes J, Wrabetz L, Mirsky R, Jessen KR (2006): TGFbeta type II receptor signaling controls Schwann cell death and proliferation in developing nerves. J Neurosci; 26(33):8417-27.

Day WA, Koishi K, McLennan IS (2003): Transforming growth factor beta 1 may regulate the stability of mature myelin sheaths. Exp Neurol; 184(2):857-64.

Dong Z, Brennan A, Liu N, Yarden Y, Lefkowitz G, Mirsky R, Jessen KR (1995): Neu differentiation factor is a neuron-glia signal and regulates survival, proliferation, and maturation of rat Schwann cell precursors. Neuron; 15(3):585-96.

Dupin E, Real C, Glavieux-Pardanaud C, Vaigot P, Le Douarin NM (2003): Reversal of developmental restrictions in neural crest lineages: transition from Schwann cells to glial-melanocytic precursors in vitro. Proc Natl Acad Sci U S A; 100(9):5229-33. 


\section{Literaturverzeichnis}

Einheber S, Hannocks MJ, Metz CN, Rifkin DB, Salzer JL (1995): Transforming growth factor-beta 1 regulates axon/Schwann cell interactions. J Cell Biol; 129(2):443-58.

Euteneuer S: Neuronal cell adhaesion molecule (NCAM) und die Rezeptortyrosinkinase Ret sind alternative Rezeptoren für Glial cell line-derived neurotrophic facor (GDNF) im Innenohr; in: 78th Annual Meeting of the German Society of Oto-Rhino-Laryngology, Head and Neck Surgery 16.05. - 20.05.2007, Munich; Springer Medizin Verlag, Lübeck 2008, 457-460.

Garratt A N, Britsch S, Birchmeier C (2000a): Neuregulin, a factor with many functions in the life of a schwann cell. Bioessays; 22(11):987-96.

Garratt AN, Voiculesco O, Topilko P, Charnay P, Birchmeier C (2000b): A dual role of erbB2 in myelination and in expansion of the Schwann cell precursor pool. J Cell Biol; 148(5):1035-46.

Ghislain J, Charnay P (2006): Control of myelination in Schwann cells: a Krox20 cisregulatory element integrates Oct6, Brn2 and Sox10 activities. EMBO Rep; 7(1):52-8.

Gilmour DT, Maischein HM, Nüsslein-Volhard C (2002): Migration and function of a glial subtype in the vertebrate peripheral nervous system. Neuron; 34(4):577-88.

Grinspan JB, Marchionni MA, Reeves M, Coulaloglou M, Scherer SS (1996): Axonal interactions regulate Schwann cell apoptosis in developing peripheral nerve: neuregulin receptors and the role of neuregulins. J Neurosci; 16(19):6107-18.

Guénard V, Gwynn LA, Wood PM (1995a): Transforming growth factor-beta blocks myelination but not ensheathment of axons by Schwann cells in vitro. J Neurosci; 15(1 Pt 1):419-28. 


\section{Literaturverzeichnis}

Guénard V, Rosenbaum T, Gwynn LA, Doetschman T, Ratner N, Wood PM (1995b): Effect of transforming growth factor-beta 1 and -beta 2 on Schwann cell proliferation on neurites. Glia; 13(4):309-18.

Hagedorn L, Suter U, Sommer L (1999): P0 and PMP22 mark a multipotent neural crest-derived cell type that displays community effects in response to TGF-beta family factors. Development; 126(17):3781-94.

He W, Ingraham C, Rising L, Goderie S, Temple S (2001): Multipotent stem cells from the mouse basal forebrain contribute GABAergic neurons and oligodendrocytes to the cerebral cortex during embryogenesis. J Neurosci; 21(22):8854-62.

Heermann S, Schmücker J, Hinz U, Rickmann M, Unterbarnscheidt T, et al. (2011) Neuregulin 1 Type III/ErbB Signaling Is Crucial for Schwann Cell Colonization of Sympathetic Axons. PLoS ONE 6(12): e28692.

Höke A, Cheng C, Zochodne DW (2000): Expression of glial cell line-derived neurotrophic factor family of growth factors in peripheral nerve injury in rats. Neuroreport; 11(8): 1651-4.

Höke A, Ho T, Crawford TO, LeBel C, Hilt D, Griffin JW (2003): Glial cell line-derived neurotrophic factor alters axon schwann cell units and promotes myelination in unmyelinated nerve fibers. J Neurosci; 23(2):561-7.

Jessen KR, Mirsky R (1992): Schwann cells: early lineage, regulation of proliferation and control of myelin formation. Curr Opin Neurobiol; 2(5):575-81.

Jessen KR, Mirsky R (1999): Why do Schwann cells survive in the absence of axons? Annals of the New York Academy of Sciences, Vol. 883, 109-115.

Jessen KR, Mirsky R (2002): Signals that determine Schwann cell identity. J Anat; 200(4):367-76. 


\section{Literaturverzeichnis}

Jessen KR, Mirsky R: Schwann cell development; in: Myelin biology and disorders (Lazzarini RA, ed.), 329-370, Elsevier Academic, London 2004, 329-370.

Jessen KR, Mirsky R (2005): The origin and development of glial cells in peripheral nerves. Nat Rev Neurosci; $\underline{6(9)}$ :671-82.

Jessen KR, Mirsky R (2008): Negative regulation of myelination: relevance for development, injury, and demyelinating disease. Glia; $\underline{56(14)}$ :1552-65.

Kahle W, Frotscher M: Taschenatlas Anatomie, Nervensystem und Sinnesorgane. 9. Auflage, Thieme Verlag, Stuttgart 2005, 38.

Koenig HL, Schumacher M, Ferzaz B, Thi AN, Ressouches A, Guennoun R, JungTestas I, Robel P, Akwa Y, Baulieu EE (1995): Progesterone synthesis and myelin formation by Schwann cells. Science; 268(5216):1500-3.

Kwon YK, Bhattacharyya A, Alberta JA, Giannobile WV, Cheon K, Stiles CD, Pomeroy SL (1997): Activation of ErbB2 during wallerian degeneration of sciatic nerve. J Neurosci; 17(21):8293-9.

Lai C (2005): Peripheral glia: Schwann cells in motion. Curr Biol; 15(9):R332-4.

Le Douarin NM, Smith J (1988): Development of the peripheral nervous system from the neural crest. Institut d'Embryologie Cellulaire et Moléculaire, du CNRS et du Collège de France, Nogent-sur-Marne. Annu Rev; 4 :375-388.

Lemke G (2001): Glial control of neuronal development. Annu Rev Neurosci; 24: 87105.

Lemke GE, Brockes JP (1984): Identification and purification of glial growth factor. J Neurosci; $\underline{4(1): 75-83 . ~}$ 


\section{Literaturverzeichnis}

Lin LF, Doherty DH, Lile JD, Bektesh S, Collins F (1993): GDNF: a glial cell linederived neurotrophic factor for midbrain dopaminergic neurons. Science; 260(5111): 1130-2.

Lin LF, Zhang TJ, Collins F, Armes LG (1994): Purification and initial characterization of rat B49 glial cell line-derived neurotrophic factor. J Neurochem; $\underline{63(2)}$ :758-68.

Lin W, Sanchez HB, Deerinck T, Morris JK, Ellisman M, Lee KF (2000): Aberrant development of motor axons and neuromuscular synapses in erbB2-deficient mice. Proc Natl Acad Sci U S A; 97(3):1299-304.

Lyons DA, Pogoda HM, Voas MG, Woods IG, Diamond B, Nix R, Arana N, Jacobs J, Talbot WS (2005): Erbb3 and erbb2 are essential for Schwann cell migration and myelination in zebrafish. Curr Biol; 15(6):513-24.

Maness PF, Beggs HE, Klinz SG, Morse WR (1996): Selective neural cell adhesion molecule signaling by Src family tyrosine kinases and tyrosine phosphatases. Perspect Dev Neurobiol; 4(2-3):169-81.

Meintanis S, Thomaidou D, Jessen KR, Mirsky R, Matsas R (2001): The neuron-glia signal beta-neuregulin promotes Schwann cell motility via the MAPK pathway. Glia; 34(1):39-51.

Michailov GV, Sereda MW, Brinkmann BG, Fischer TM, Haug B, Birchmeier C, Role L, Lai C, Schwab MH, Nave KA (2004): Axonal neuregulin-1 regulates myelin sheath thickness. Science; 304(5671):700-3.

Mirsky R, Jessen KR (1996): Schwann cell development, differentiation and myelination. Curr Opin Neurobiol; 6(1):89-96.

Nosrat CA, Tomac A, Hoffer BJ, Olson L (1997): Cellular and developmental patterns of expression of Ret and glial cell line-derived neurotrophic factor receptor alpha mRNAs. Exp Brain Res; 115(3):410-22. 


\section{Literaturverzeichnis}

Paratcha G, Ledda F, Ibáñez CF (2003): The neural cell adhesion molecule NCAM is an alternative signaling receptor for GDNF family ligands. Cell; 113(7):867-79.

Rao MS, Mayer-Proschel M (1997): Glial-restricted precursors are derived from multipotent neuroepithelial stem cells. Dev Biol; 188(1):48-63.

Riethmacher D, Sonnenberg-Riethmacher E, Brinkmann V, Yamaai T, Lewin GR, Birchmeier C (1997): Severe neuropathies in mice with targeted mutations in the ErbB3 receptor. Nature; 389(6652):725-30.

Rønn LC, Berezin V, Bock E. (2000): The neural cell adhesion molecule in synaptic plasticity and ageing. Int J Dev Neurosci; 18(2-3):193-9.

Russell JW, Cheng HL, Golovoy D (2000): Insulin-like growth factor-I promotes myelination of peripheral sensory axons. J Neuropathol Exp Neurol; 59(7):575-84.

Sariola H, Saarma M (2003): Novel functions and signalling pathways for GDNF. J Cell Sci; 116(Pt 19):3855-62.

Schachner M (1997): Neural recognition molecules and synaptic plasticity. Curr Opin Cell Biol; $\underline{9(5)}: 627-34$.

Scherer SS, Salzer JL: Axon- Schwann cell interactions in peripheral nerve regeneration; in: Glial Cell Development (eds. Jessen, K.R. \& Richardson, W.D.), Bios Scientific Publishers, Oxford 1996, 165-198.

Schiebler TH: Anatomie. 9. Auflage, Springer Verlag, Heidelberg, 2005, 112.

Shah NM, Marchionni MA, Isaacs I, Stroobant P, Anderson DJ (1994): Glial growth

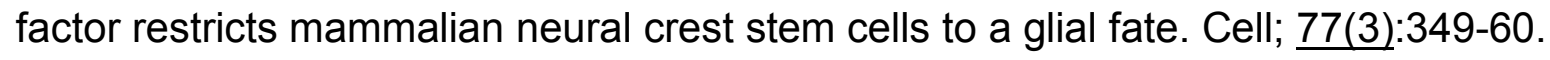

Springer JE, Mu X, Bergmann LW, Trojanowski JQ (1994): Expression of GDNF mRNA in rat and human nervous tissue. Exp Neurol; 127(2): 167-70. 


\section{Literaturverzeichnis}

Stewart HJS, Brennan A, Rahman M, Zoidl G, Mitchell PJ, Jessen KR, Mirsky R (2001): Developmental regulation and overexpression of the transcription factor AP2, a potential regulator of the timing of Schwann cell generation. Eur J Neurosci; 14(2):363-72.

Taveggia C, Zanazzi G, Petrylak A, Yano H, Rosenbluth J, Einheber S, Xu X, Esper RM, Loeb JA, Shrager P, Chao MV, Falls DL, Role L, Salzer JL (2005): Neuregulin-1 type III determines the ensheathment fate of axons. Neuron; $\underline{47(5): 681-94 .}$

Thomaidou D, Coquillat D, Meintanis S, Noda M, Rougon G, Matsas R (2001): Soluble forms of NCAM and F3 neuronal cell adhesion molecules promote Schwann cell migration: identification of protein tyrosine phosphatases zeta/beta as the putative F3 receptors on Schwann cells. J Neurochem; 78(4): 767-78.

Trupp M, Belluardo N, Funakoshi H, Ibáñez CF (1997): Complementary and overlapping expression of glial cell line-derived neurotrophic factor (GDNF), c-ret proto-oncogene, and GDNF receptor-alpha indicates multiple mechanisms of trophic actions in the adult rat CNS. J Neurosci; 17(10):3554-67.

Wolpowitz D, Mason TB, Dietrich P, Mendelsohn M, Talmage DA, Role LW (2000): Cysteine-rich domain isoforms of the neuregulin-1 gene are required for maintenance of peripheral synapses. Neuron; 25(1):79-91.

Wood P, Moya F, Eldridge C, Owens G, Ranscht B, Schachner M, Bunge M, Bunge $R$ (1990): Studies of the initiation of myelination by Schwann cells. Ann N Y Acad Sci; $\underline{605: 1-14 .}$

Yamauchi J, Miyamoto Y, Chan JR, Tanoue A (2008): ErbB2 directly activates the exchange factor Dock7 to promote Schwann cell migration. J Cell Biol; 181(2):35165 .

Yarden Y, Sliwkowski MX (2001): Untangling the ErbB signalling network. Nat Rev Mol Cell Biol; 2(2): 127-37. 
Zeng YX, Somasundaram K, El-Deiry WS (1997): AP-2 inhibits cancer cell growth and activates p21WAF/CIP1 expression. Nature Genet 15: 78-82.

Zhang L, Ma Z, Smith GM, Wen X, Pressman Y, Wood PM, Xu XM (2009): GDNFenhanced axonal regeneration and myelination following spinal cord injury is mediated by primary effects on neurons. Glia; $\underline{57(11)}: 1178-91$.

Zhang SM, Marsh R, Ratner N, Brackenbury R (1995): Myelin glycoprotein P0 is expressed at early stages of chicken and rat embryogenesis. J Neurosci Res; 40 (2):241-50. 


\section{Danksagung}

Zunächst möchte ich mich bei meinem Betreuer, Herrn Dr. med. S. Heermann, für die Unterstützung während der Planung und Durchführung meiner Arbeit bedanken. Er war mit seinen konstruktiven Vorschlägen eine große Hilfe und hatte immer ein offenes Ohr für Fragen und Probleme. Außerdem vermittelte er mir auch über die Doktorarbeit hinaus wissenschaftliche Kenntnisse und Fähigkeiten im Bereich der Laborarbeit, die für meinen zukünftigen beruflichen Altag von Wichtigkeit sein können.

Ich danke Herrn PD Dr. M. Rickmann für die Überlassung des interessanten Themas und die geduldige und hilfsbereite Unterstützung und vor allem seine freundliche Art, mit seinen Mitarbeitern umzugehen.

Eine Danksagung gilt meinen Arbeitskollegen des Labors der Neuroanatomie, denen ich für die Hilfsbereitschaft zu Dank verpflichtet bin. Auf ihre Hilfe und Unterstützung konnte man sich immer verlassen. 